\title{
Expedition 318 summary ${ }^{1}$
}

\author{
Expedition 318 Scientists $^{2}$
}

\section{Chapter contents}

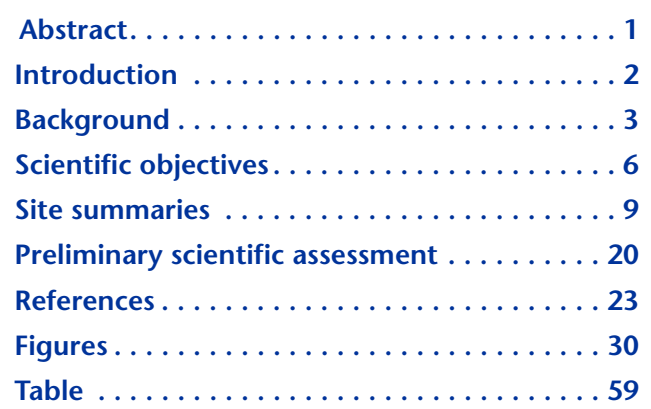

${ }^{1}$ Expedition 318 Scientists, 2011. Expedition 318 summary. In Escutia, C., Brinkhuis, H., Klaus, A., and the Expedition 318 Scientists, Proc. IODP, 318: Tokyo (Integrated Ocean Drilling Program Management International, Inc.). doi:10.2204/iodp.proc.318.101.2011

'Expedition 318 Scientists' addresses.

\section{Abstract}

Understanding the evolution and dynamics of the Antarctic cryosphere, from its inception during the Eocene-Oligocene transition ( $34 \mathrm{Ma})$ through the significant subsequent periods of likely coupled climate and atmospheric greenhouse gas changes, is not only of major scientific interest but also is of great importance for society. Drilling the Antarctic Wilkes Land margin along an inshore to offshore transect was designed to provide a long-term record of the sedimentary archives of Cenozoic Antarctic glaciation and its intimate relationships with global climatic and oceanographic change. The principal goals were

1. To establish the timing and nature of the first arrival of ice at the Wilkes Land margin inferred to have occurred during the earliest Oligocene (reflecting Oligocene isotope Event 1 around $\sim 34 \mathrm{Ma}$ ),

2. To reconstruct the nature and age of the changes in the geometry of the progradational wedge interpreted to correspond with large fluctuations in the extent of the East Antarctic Ice Sheet and possibly coinciding with the transition from a wetbased to a cold-based glacial regime,

3. To obtain a high-resolution record of Antarctic climate variability during the late Neogene and Quaternary, and

4. To obtain an unprecedented ultrahigh resolution (i.e., annual to decadal) Holocene record of climate variability.

The Wilkes Land drilling program was developed to constrain the age, nature, and paleoenvironment of deposition of the previously only seismically inferred glacial sequences. Drilling the Wilkes Land margin has a unique advantage in that seismic unconformity WL-U3, inferred to separate preglacial strata below from glacial strata above in the continental shelf, can be traced to the continental rise deposits, allowing sequences to be linked from shelf to rise.

Integrated Ocean Drilling Program Expedition 318, carried out in January-March 2010 (Wellington, New Zealand, to Hobart, Australia), recovered $2000 \mathrm{~m}$ of high-quality middle Eocene-Holocene sediments from Sites U1355, U1356, U1359, and U1361 on the Wilkes Land rise and Sites U1357, U1358, and U1360 on the Wilkes Land shelf at water depths between $\sim 400$ and 4000 meters below sea level. Together, the cores represent $\sim 53$ m.y. of Antarctic history. Recovered cores successfully date the inferred glacial seismic units (WL-S4-WL-S9). The cores reveal the history of the Wilkes 
Land Antarctic margin from an ice-free "greenhouse Antarctica," to the first cooling, to the onset and erosional consequences of the first glaciation and the subsequent dynamics of the waxing and waning ice sheets, all the way to thick, unprecedented "tree ring style" records with seasonal resolution of the last deglaciation that began $\sim 10,000 \mathrm{y}$ ago. The cores also reveal details of the tectonic history of the so called Australo-Antarctic Gulf from 53 Ma portraying the onset of the second phase of rifting between Australia and Antarctica, to ever subsiding margins and deepening, all the way to the present continental and ever widening ocean/continent configuration. Tectonic and climatic change turned the initially shallow broad subtropical Antarctic Wilkes Land shelf into a deeply subsided basin with a narrower, ice-infested margin. Thick Oligocene and notably Neogene deposits, including turbidites, contourites, and larger and smaller scaled debris mass flows, witness the erosional power of the waxing and waning ice sheets and deep ocean currents. The recovered clays, silts, and sands and their microfossils also reveal the transition of subtropical ecosystems and a vegetated Antarctica into sea ice-dominated ecosystems bordered by calving glaciers, separated by seismic unconformity WL-U3.

\section{Introduction}

Polar ice is an important component of the modern climate system, affecting global sea level, ocean circulation and heat transport, marine productivity, air-sea gas exchange, and planetary albedo, among others. The modern semipermanent ice caps are, geologically speaking, a relatively young phenomenon. Since mid-Permian ( $270 \mathrm{Ma})$ times, parts of Antarctica became reglaciated only $\sim 34$ m.y. ago, whereas full scale, permanent Northern Hemisphere continental ice began only 2.7 to $\sim 3$ m.y. ago (e.g., Zachos et al., 2008) (Fig. F1). In a broad sense, the record of Antarctic glaciation from the time of first ice sheet inception (presumed to incept around the Eocene/Oligocene boundary; Oligocene isotope Event 1 [Oi-1] glaciation; e.g., Miller et al., 1985) through the significant periods of climate change during the Cenozoic, such as the Oligocene/Miocene boundary, the Miocene isotope Event 1 (Mi-1) (e.g., Miller et al., 1985), the mid-Miocene climatic optimum, late Neogene cooling, early Pliocene warming events, the Quaternary glacial-interglacial cycles, and the concomitant biotic and paleoceanographic evolution, is not only of scientific interest but also is of great importance for society. State-of-the-art climate models (e.g., DeConto and Pollard, 2003a, 2003b; Huber et al., 2004; DeConto et al., 2007; Pollard and DeConto, 2009) combined with paleoclimatic proxy data (e.g.,
Pagani et al., 2005) suggest that the main triggering mechanism for inception and development of the Antarctic ice sheet were the decreasing levels of $\mathrm{CO}_{2}$ (and other greenhouse gas) concentrations in the atmosphere (Figs. F1, F2) and that the opening of critical Southern Ocean gateways (e.g., Kennett, 1977; DeConto and Pollard, 2003a, 2003b; Huber et al., 2004; Barker and Thomas, 2004) played only a secondary role. With current rising atmospheric greenhouse gases resulting in rapidly increasing global temperatures (Intergovernmental Panel on Climate Change [IPCC], 2007; www.ipcc.ch/), studies of polar climates are prominent on the research agenda. Understanding Antarctic ice sheet dynamics and stability is of special relevance because, based on IPCC (2007) forecasts, atmospheric $\mathrm{CO}_{2}$ doubling and a $1.8^{\circ}-4.2^{\circ} \mathrm{C}$ temperature rise is expected by the end of this century. The lower values of these estimates have not been experienced on our planet since 10-15 Ma, and the higher estimates have not been experienced since before the ice sheets in Antarctica formed (Fig. F3).

Since their inception, the Antarctic ice sheets appear to have been very dynamic, waxing and waning in response to global climate change over intermediate and even short (orbital) timescales (e.g., Wise et al., 1991; Zachos et al., 1997; Barker, Camerlenghi, Acton, et al., 1999; DeConto and Pollard, 2003a, 2003b; Pollard and DeConto, 2009). Yet, not much is known about the nature, cause, timing, and rate of processes involved. Past ocean drilling into the Antarctic continental shelf and basins in Prydz Bay and the Ross Sea (i.e., Ocean Drilling Program [ODP] Legs 119 and 188, Deep Sea Drilling Program [DSDP] Leg 28, and Cape Roberts Project) indicates two basic states of the Antarctic ice sheets: (1) an early phase lasting from $\sim 34$ to $\sim 14$ Ma with a less stable ice cover characterized by strong cyclic waxing and waning (O'Brien et al., 2001; Barrett, 2009; Zachos et al., 1997, 2008; Wade and Pälike, 2004; Pälike et al., 2006) and (2) a later (from $\sim 14$ Ma to recent) phase when deep-sea isotope records (e.g., Miller et al., 1985; Flower and Kennett, 1994) indicate that the Antarctic ice sheets became a quasipermanent and more stable feature sustaining polar climates. However, even these "stable" ice sheets may have varied considerably in size, perhaps by as much as $25 \mathrm{~m}$ of sea level equivalent (SLE) (Kennett and Hodell, 1993; Pollard and DeConto, 2009; Naish et al., 2009). Of the two main ice sheets, the West Antarctic Ice Sheet (WAIS) (Fig. F4) is mainly marine based and is considered less stable. The East Antarctic Ice Sheet (EAIS), which overlies continental terrains that are largely above sea level, is considered stable and is believed to respond only slowly to changes in climate. However, reports of beach gravel deposited $20 \mathrm{~m}$ 
above sea level in Bermuda and the Bahamas from 420 to $360 \mathrm{ka}$ indicate the collapse of not only the WAIS ( $6 \mathrm{~m}$ of SLE) and Greenland ice sheet $(6 \mathrm{~m}$ of SLE), but possibly also $8 \mathrm{~m}$ of SLE from East Antarctic ice sources (Hearty et al., 1999). Therefore, during episodes of global warmth, with likely elevated atmospheric $\mathrm{CO}_{2}$ conditions, the EAIS may contribute just as much or more to rising global sea level as the proverbial unstable Greenland ice sheet. In the face of rising $\mathrm{CO}_{2}$ levels (IPCC, 2007), a better understanding of the EAIS dynamics is therefore urgently needed from both an academic as well as a societal point of view.

A key region for analysis of the long- and short-term behavior of the EAIS is the eastern sector of the Wilkes Land margin, located at the seaward termination of the largest East Antarctic subglacial basin, the Wilkes subglacial basin (Fig. F5) (Drewry, 1983; Ferraccioli et al., 2001, 2007, 2009). The base of the portion of the EAIS draining through the Wilkes subglacial basin is largely below sea level, suggesting that this portion of the EAIS can potentially be less stable than other areas of the EAIS. Numerical models of ice sheet behavior (e.g., Huybrechts, 1993; DeConto and Pollard, 2003a, 2003b; DeConto et al., 2007; Pollard and DeConto, 2009) (Fig. F2) provide a basic understanding of the climatic sensitivity of particular Antarctic regions for early ice sheet formation, connection and expansion, and eventual development of the entire ice sheet. For example, in these models glaciation is shown to have begun in the East Antarctic interior, discharging mainly through the Lambert Graben to Prydz Bay. These models imply that the EAIS did not reach the Wilkes Land margin until a later stage. These models must now be validated through drilling and obtaining concrete evidence from the sedimentary record. Sediments from Prydz Bay cores drilled during Leg 188 (O'Brien, Cooper, Richter, et al., 2001; Cooper, O'Brien, and Richter, 2004) provided records from the Late Cretaceous and early late Eocene preglacial and relatively warm climates to the full glacial conditions of the Pliocene-Pleistocene. Like at Prydz Bay, the timing and mode of the onset of glaciation at the Wilkes Land Continental Margin is still unknown but is essential for providing age constraints for models of EAIS development and changes in its volume. Moreover, detailed portrayal of the subsequent Cenozoic history and dynamics of the Antarctic glacial cycles at Wilkes Land will provide further constraints for model experiments and future predictions about EAIS stability.

Conceivably even more important than the history of the Antarctic glaciations are past lessons of deglaciations and periods of exceptional warmth. Seismic surveys and pilot studies indicate that the Wilkes
Land margin also includes sites of ultrahigh accumulation rates of sediments recording the Holocene deglaciation and subsequent climate and sedimentological variability extending over the past 10,000 y. One of the expedition objectives was to recover and analyze a unique $\sim 200 \mathrm{~m}$ sequence of likely annually layered sediments. These seasonally laminated (tree ring style) deposits consist predominantly of phytoplankton remains and potentially constitute one of the world's most expanded archives of environmental change extending through the Holocene. We also planned to core several sequences from the Pleistocene and Pliocene that formed during interglacial intervals of exceptional warmth, periods that may provide valuable information about Antarctica's response to warming predicted in the centuries ahead.

\section{Background}

\section{Physiographic and geologic setting}

The Adélie and George V coasts of the eastern Wilkes Land margin drain the EAIS with a mostly divergent flow pattern (Fig. F4). Ice cliffs and two prominent outlet glaciers, the Mertz and the Ninnis, characterize the present coastline. These outlet glaciers extend seaward as ice tongues and have an important role in ice drainage and sediment delivery to the ocean (Anderson et al., 1980; Drewry and Cooper, 1981). Drainage velocities in outlet glaciers range from $>500$ to $\sim 3700 \mathrm{~m} / \mathrm{y}$ (Fig. F4) (Lindstrom and Tyler, 1984; MacDonald et al., 1989), whereas drainage in the areas between outlet glaciers, occupied by ice cliffs and tidewater glaciers, may range from a few meters to tens of meters every year (Anderson, 1999). In the eastern Wilkes Land margin the continental shelf has an average width of $125 \mathrm{~km}$ and an average water depth of 450-500 meters below sea level (mbsl) (Fig. F6). As commonly observed around Antarctica, the shelf exhibits an overdeepened and landward-sloping bathymetric profile that is caused principally by glacial erosion and flexural loading by grounded ice (Ten Brink and Cooper, 1992). The topography is irregular, with depths from $200 \mathrm{mbsl}$ on outer shelf banks to $1000 \mathrm{mbsl}$ in shelf troughs. The troughs, which shoal as they traverse from inner shelf $(>1000 \mathrm{mbsl})$ to outer shelf $(500 \mathrm{mbsl})$, were formed by ice streams extending across the shelf during times of glacial maxima. The adjacent outer shelf banks are areas that have been bypassed by the most recent ice streams and where grounded ice has been relatively immobile or stagnant. The continental slope is steep (1:9-1:30) and narrow (15 km average, but as wide as $25 \mathrm{~km}$ ) and extends from the shelf break to $2000-2500$ mbsl. The continental rise is also steep, with average gradients between 1:100 and $1: 150$. 
The eastern Wilkes Land Continental Margin, conjugate to the southern Australian margin, formed during the Late Cretaceous separation of Australia and Antarctica (Cande and Mutter, 1982; Sayers et al., 2001; Veevers, 1987; Colwell et al., 2006; O'Brien and Stagg, 2007; Leitchenkov et al., 2007; Close et al., 2009). Slow seafloor spreading began between Australia and Antarctica in the Late Cretaceous, with the precise timing of onset still under debate ( $\sim 83 \mathrm{Ma}$, according to Sayers et al., 2001). At $\sim 50 \mathrm{Ma}$ (middle Eocene), rapid seafloor spreading commenced in the Australian-Antarctic Basin (AAB) as Australia continued to move northward from Antarctica (Cande and Mutter, 1982; Colwell et al., 2006; Close et al., 2009), with the final clearance of the Australian and Antarctic plates southwest of the South Tasman Rise taking place by the middle late Eocene ( 35.5 Ma) (Exon et al., 2004; Stickley et al., 2004). This resulted in the establishment of more open marine conditions and eventually the development of the Antarctic Circumpolar Current in the Miocene. The continental crust underlying the thick postrift and synrift sediments in the eastern Wilkes Land/Terre Adélie margin extends $>400 \mathrm{~km}$ seaward of the shelf break (Close et al., 2009). This seaward salient, named the Adélie Rift Block, is associated with anomalously shallow bathymetry, an atypical continental margin free-air gravity edge-effect anomaly, and an absence of magnetic anomalies related to seafloor spreading. This salient, which is underlain by stretched continental crust and pre- and synrift sediment, is interpreted as a deeply subsided marginal plateau (Colwell et al., 2006; Close et al., 2009).

The stratigraphy of the eastern Wilkes Land margin is known mainly from the seismic stratigraphic analyses of numerous multichannel seismic reflection surveys in the eastern Wilkes Land margin (Sato et al., 1984; Wannesson et al., 1985; Tsumuraya et al., 1985; Eittreim and Hampton, 1987; Ishihara et al., 1996; Tanahashi et al., 1997; Brancolini et al., 2000; Stagg et al., 2004) complemented by surficial gravity and piston sediment cores (Payne and Conolly, 1972; Hampton et al., 1987; Domack et al., 1980; Domack, 1982; Tsumuraya et al., 1985; Ishihara et al., 1996; Tanahashi et al., 1997; Brancolini et al., 2000; Escutia et al., 2003; Michel et al., 2006; Leventer et al., 2006), dredging (Mawson 1940, 1942; Domack et al., 1980; Sato et al., 1984; Leventer et al., 2001), and limited deep geological sampling recovery at DSDP Site 269 (Hayes, Frakes, et al., 1975).

\section{Pre-ice sheet stratigraphy}

Presumed pre-Oligocene synrift strata are as thick as $\sim 3 \mathrm{~km}$ and are highly variable in seismic character, with discontinuous, faulted, and tilted strata onlap- ping the flanks of the acoustic basement (Eittreim and Smith, 1987; Eittreim, 1994; De Santis et al., 2003; Stagg et al., 2004; Leitchenkov et al., 2007; Close et al., 2009; De Santis et al., 2010). Postrift strata across the eastern Wilkes Land margin may be as thick as $5 \mathrm{~km}$, well layered on the continental rise, and less stratified and discontinuous landward (Eittreim and Smith, 1987; Wannesson, 1990; Tanahashi et al., 1994; Eittreim, 1994; De Santis et al., 2003). On the continental shelf, a prominent regional unconformity (WL-U3) within the Cenozoic postrift section (Fig. F7) has been interpreted to record erosional processes related to the first advance of grounded ice sheets onto the continental shelf (Eittreim and Smith, 1987; Tanahashi et al., 1994; Eittreim et al., 1995; Escutia et al., 1997).

Prior to Expedition 318, the only pre-ice sheet strata sampled from this margin were a series of dredges from the inner continental shelf and slope. Erosion by late Cenozoic glaciers near the Mertz ice tongue exposed Mesozoic sediments at the seafloor, which allowed recovery of lignite (Mawson, 1940, 1942) and Lower Cretaceous brecciated carbonaceous siltstone (Domack et al., 1980). Dredges collected in the area by Leventer et al. (2001) also recovered Paleogene lignites with reworked Early Cretaceous flora. Dredging of the upper continental slope off Terre Adélie sampled Oligocene and Miocene limestones and undated sedimentary, metamorphic, and igneous rocks of mostly ice-rafted origin (Sato et al., 1984).

\section{Continental margin glacial stratigraphy}

Glacial sequences on the shelf thicken seaward in prograding wedges (Fig. F7). The sequences are deeply eroded by broad troughs that cross the shelf. Foreset strata are commonly truncated at or near the seafloor beneath the troughs. Topset strata form the banks adjacent to the troughs.

Two main unconformities of regional character, unconformities WL-U3 and WL-U8, are identified as truncating the seismic sequences on the shelf (Wannesson et al., 1985; Eittreim and Smith, 1987; Hampton et al., 1987; Escutia et al., 1997; De Santis et al., 2003) (Fig. F7). The erosional events represented by these unconformities are interpreted to result from grounded ice sheets moving across the continental shelf (Tanahashi et al., 1994; Eittreim et al., 1995, Escutia et al., 1997). Eittreim et al. (1995) calculated an erosion of 300-600 $\mathrm{m}$ of strata below unconformity WL-U3 and of 350-700 $\mathrm{m}$ of strata below unconformity WL-U8. Unconformity WL-U3 marks the start of progradation in this sector of the Wilkes Land margin. Across unconformity WL-U8, a change in the geometry of the outer shelf progradational 
wedge, from shallower dips below unconformity WL-U8 to steeper dips above (foreset slopes as much as $\sim 10^{\circ}$ ), can be recognized.

Seismic units have been correlated from shelf to rise and abyssal plain by tracing and projecting unconformities and seismic units. Seismic units above unconformity WL-U8 downlap and pinch out at the base of the continental slope, but deeper units (i.e., between unconformities WL-U8 and WL-U3) continue across the margin (Hampton et al., 1987; Eittreim et al., 1995; Escutia et al., 1997; De Santis et al., 2003) (Fig. F7). The principal marker is unconformity WL-U3, which in Wilkes Land can be traced from the shelf, where it marks the onset of progradation on the Wilkes Land margin (Eittreim and Smith, 1987), to the rise, where it correlates with an upsection increase in turbidite and contourite deposition (Escutia et al., 1997, 2000; Donda et al., 2003) (Fig. F8).

On the eastern Wilkes Land continental rise, strata above unconformity WL-U3 include six glacial-related seismic units (WL-S4-WL-S9) (De Santis et al., 2003; Donda et al., 2003) (Fig. F8). The two deepest units, WL-S4 and WL-S5, consist of stratified and continuous reflectors that onlap at the base of the slope (Escutia et al., 1997; Donda et al., 2003). Acoustic signatures of isolated channel-levee complexes that characterize turbidite deposition are first observed during deposition of Unit WL-S5 (Escutia et al., 1997; Donda et al., 2003). Channel-levee complexes became widespread during deposition of Units WLS6 and WL-S7, and turbidity flows were likely the dominant process building the large sedimentary ridges on the rise. Wavy reflectors that are characteristic of bottom contour-current deposition occur on the lower rise in Unit WL-S6 and on the upper rise in Unit WL-S7. Unit WL-S8 mostly fills previous depressions, although there is evidence for bottom contour-current and turbidite flows (Escutia et al., 2002; Donda et al., 2003). Unit WL-S9 is a discontinuous unit on the rise and, where present, is composed of channel and levee complexes and layered reflectors (Donda et al., 2003).

During the interglacial open-marine Holocene, thick laminated diatom mud and oozes were deposited in deep (>1000 mbsl) inner shelf basins, including the Adélie Drift (Costa et al., 2007) (Figs. F6, F9, F10, F11). Based on accelerator mass spectrometry radiocarbon dates on a $50 \mathrm{~m}$ long sediment core, this drift has unusually high accumulation rates, as much as 20-21 m/k.y. Opal, Ti, and Ba time series show decadal to century variance suggestive of solar forcing and El Niño Southern Oscillation (ENSO) forcing (Crosta et al., 2005; Denis et al. 2006; Leventer et al., 2006; Maddison et al., 2006; Costa et al., 2007).

\section{Previous drilling on the Wilkes Land margin}

Site 269 was drilled during Leg 28 on the eastern Wilkes Land abyssal plain to determine the geologic and climate history of Antarctica and the Southern Ocean (Hayes, Frakes, et al., 1975). Site 269 is north of the Expedition 318 drill area and was intermittently cored to 958 meters below seafloor (mbsf) in a water depth of $4285 \mathrm{mbsl}$, with $42 \%$ recovery of (?)Eocene-Holocene rocks (Hayes, Frakes, et al., 1975). The cored sections consist predominantly of silts and clays with variable amounts of microfossils. Diatom oozes and diatom mud dominate the upper half of the section, which is dated as Quaternary to late Miocene in age (Hayes, Frakes, et al., 1975). In the lower half, which is late(?) Eocene to late Miocene in age, diatoms are absent but calcareous nannofossils are found in trace amounts, with abundant palynomorphs including dinoflagellate cysts (dinocysts) and sporomorphs (Kemp et al., 1975). There is a transition in facies from more distal facies in the lower part of the hole to more proximal facies near the surface. Piper and Brisco (1975) interpret this facies change as a result of substantially increased supply of sand, coarse silt, and clay from the Antarctic continent, possibly in response to progradation of the continental margin. The cores document extensive Antarctic glaciation beginning at least by Oligocene to early Miocene times and indicate that water temperatures were cool to temperate in the late Oligocene and early Miocene and then cooled during the Neogene, presumably as glaciation intensified.

\section{Inferred long-term record of glaciation}

Unconformity WL-U3 is interpreted to mark the first preserved grounding of an ice sheet across Wilkes Land, eroding the continental shelf (Tanahashi et al., 1994; Eittreim et al., 1995; Escutia et al., 1997, 2005), $\sim 40$ m.y. ago (Eittreim et al., 1995) to 33.5 to $30 \mathrm{Ma}$ (Escutia et al., 2005) (Fig. F12). Early glacial strata (e.g., likely glacial outwash deposits) above unconformity WL-U3 were delivered by fluctuating temperate glaciers and deposited as low dip-angle prograding foresets. The increase in stratal dips across unconformity WL-U8 in the prograding wedge at the shelf edge is interpreted to record a change in the glacial regime inferred to correspond with the transition from intermittent fluctuating glaciers to persistent oscillatory ice sheets during the late Miocene-early Pliocene (Escutia et al., 2005), or $\sim 3$ Ma (Rebesco et al., 2006) (Fig. F12). The steep foresets above unconformity WL-U8 likely consist of ice proximal (i.e., water-lain till and debris flows) and open-water sediments deposited as grounded ice sheets extended intermittently onto the outer shelf, similar to sediments recovered from ODP Site 1167 on the Prydz Trough 
mouth fan (O'Brien, Cooper, Richter, et al., 2001; Passchier et al., 2003).

On the continental rise, the upsection from seismic facies indicative of distal turbidites to large channellevee systems modified by bottom contour-current deposition likely resulted from enhanced shelf progradation. Maximum rates of sediment delivery to the rise are reported during the development of seismic Units WL-S6 and WL-S7, interpreted to be of Miocene age (Escutia et al., 1997, 2000, 2005; De Santis et al., 2003) (Fig. F12). During deposition of seismic Units WL-S8 and WL-S9, sediment supply to the lower continental rise decreased and depocenters shifted landward to the base of the slope and outer shelf (Escutia et al., 2002, 2005; De Santis et al., 2003; Donda et al., 2003). Inferred age for Units WLS8 and WL-S9 is Pliocene to Holocene (De Santis et al., 2003). Unit WL-S9 is inferred to be deposited under a polar regime with a persistent ice sheet during the Pliocene-Pleistocene. At that time, most sediment delivered to the margin was trapped on the outer shelf and slope, forming steep prograding wedges, with some sediment bypassing the slope in channelized turbidity currents (Escutia et al., 2002, 2005; De Santis, 2003) (Figs. F7, F8).

During the Holocene, thick open-water interglacial sections of diatom mud and oozes are deposited in deep inner shelf basins (Domack, 1982; Dunbar et al., 1985; Crosta et al., 2005; Denis et al., 2006; Leventer et al., 2006; Maddison et al., 2006; Costa et al., 2007). These sediments hold an ultrahigh resolution record of climate variability and provide a means of tracking interannual- to centennial-scale variability in the response of the ocean to forcing by solar processes, ENSO, and the Southern Annular Mode (SAM).

\section{Scientific objectives}

The overall aim of drilling the Wilkes Land margin is to obtain a long-term record of Antarctic glaciation and its relationships with global paleoclimatic and paleoceanographic changes along the inshoreoffshore transect (Fig. F6). Of particular interest are testing the sensitivity of the EAIS to episodes of global warming and the detailed analysis of critical periods in Earth's climate history (i.e., the EoceneOligocene and Oligocene-Miocene glaciations, middle Miocene, Pliocene, and the last deglaciation) during which the Antarctic cryosphere evolved in a step-wise fashion to ultimately assume its presentday configuration, characterized by a relatively stable EAIS.

To attain these objectives we obtained sedimentary records along the inshore-offshore gradient to con- strain the age, nature, and environments of deposition inferred from seismic surveys of the Wilkes Land continental shelf, rise, and abyssal plain (Fig. F12). The expected improved chronostratigraphy and integrated multidisciplinary climatic proxy reconstructions are essential to provide accurate constraints for models of the dynamic development of the Antarctic ice sheet and sensitivity to global climate change (Fig. F2).

\section{Specific scientific objectives}

\section{Timing and nature of the onset of glaciation at the Wilkes Land margin}

The timing and nature of the first arrival of the ice sheet at the Wilkes Land margin, the so-called "onset" of glaciation, is inferred to have occurred during the earliest Oligocene (Fig. F12). The late middle Eocene to early Oligocene is thought to represent a long-term episode of global cooling, the culmination of which led to Antarctic ice sheet development. Ice sheet development is presumed to have been a response to decreasing atmospheric greenhouse gas concentrations (Figs. F1, F2) rather than the opening of Southern Ocean conduits like the Drake and Tasman gateways (e.g., Pagani et al., 2005; DeConto and Pollard, 2003a, 2003b; Huber et al., 2004). For example, earlier ODP drilling around Tasmania (ODP Leg 189) indicated that the deepening of the Tasmanian Gateway is significantly older than the Eocene/ Oligocene boundary (Brinkhuis et al., 2003a, 2003b; Sluijs et al., 2003; Huber et al., 2004; Stickley et al., 2004). The pronounced deep-sea benthic foraminifer $\delta^{18} \mathrm{O}$ Oi-1 isotope event (Miller et al., 1985; Zachos et al., 1997; Coxall et al., 2005; Pälike et al., 2006) is widely regarded as marking the strongest step of rapid continental ice growth on Antarctica (Fig. F1) with concomitant strong sea level response. However, more recent studies (e.g., Coxall et al., 2005) indicate that this onset was in fact a two-step phased event. In any case, following the initiation of a significant Antarctic cryosphere, there are many indications that it was relatively unstable with cyclic alternations of waxing and waning that show strong orbital forcing components (e.g., O'Brien, Cooper, Richter, et al., 2001; Barrett et al., 2003; Pälike et al., 2006; DeConto et al., 2007). The mid-Oligocene transition (Rupelian/Chattian boundary; 30 Ma), likely reflected by the Oi-2b isotope event (Van Simaeys et al., 2005; Pälike et al., 2006), represents another strong cooling phase associated with a major eustatic fall that likely represents a large Antarctic ice sheet expansion. Cores from the Ross Sea (Cape Roberts Project) suggest that the onset of glaciation at that margin occurred at 34$33 \mathrm{Ma}$ (e.g., Florindo et al., 2005). Results from ODP drilling in Prydz Bay are inconclusive regarding the 
timing of the onset of glaciation along the Antarctic margin in that sector (e.g., Macphail and Truswell, 2004; Cooper et al., 2004). Ice sheet development models (Huybrechts, 1993; DeConto and Pollard, 2003a, 2003b; DeConto et al., 2007) suggest that the arrival of the first ice sheet to the Wilkes Land margin may have taken place at a somewhat later time (Fig. F2). Constraints on the age and nature of the onset of glaciation in the Wilkes Land margin expected from continental shelf sites (U1358 and U1360) and continental rise Sites U1355 and U1356 are therefore essential to providing age constraints for models of Antarctic ice sheet development.

\section{Fluctuations in the glacial regime during the Miocene(?) and transition from wet-based to cold-based glacier regimes (late Miocene- Pliocene?)}

The latest Oligocene to middle Miocene was characterized by a wet-based dynamic ice sheet that fluctuated in size. The Oligocene/Miocene boundary $(\sim 23 \mathrm{Ma})$ is marked by a major excursion in benthic foraminifer $\delta^{18} \mathrm{O}$ (Mi-1 glaciation) (e.g., Miller et al., 1985; Zachos et al., 2001, 2008) (Fig. F1). In the early Miocene, a general trend toward moderately larger ice sheets, tracking global cooling, was interrupted by the middle Miocene climatic optimum from $\sim 17$ to $14 \mathrm{Ma}$ (Zachos et al., 2001; Lewis et al., 2007) (Fig. F1). At the mid-Miocene transition ( $14 \mathrm{Ma})$ and shortly afterward, again tracking apparent renewed global cooling, the benthic foraminifer oxygen isotopic records imply that the EAIS evolved from a wet-based dynamic setting into a cold-based semipermanent ice sheet. However, even this aspect is highly controversial because some records from the Antarctic continent and margin indicate the presence of a highly dynamic ice sheet from late Miocene into early Pliocene times (e.g., Hambrey and McKelvey, 2000a, 2000b; Webb et al., 1996; Hambrey et al., 2003; Whitehead and Bohaty, 2003; Whitehead et al., 2003, 2004; Naish et al., 2009; Escutia et al., 2009). The glaciomarine continental shelf deposits recovered from Site U1358 and continental rise deposits from Site U1356 are expected to provide the required chronostratigraphic and paleoenvironmental records to help solve this controversy.

\section{Distal record of climate variability during the late Neogene and the Quaternary}

The record of the middle Miocene climatic optimum and the transition from a dynamic to a persistent ice sheet, inferred to have occurred at the Wilkes Land margin during the late Miocene-Pliocene (Fig. F12), were sampled at the continental rise Sites U1359 and U1361. Additionally, at these sites we planned to ex- plore the stability of the ice sheet during the late Miocene and, together with the record obtained at Site U1358, the extremely warm early Pliocene events, which has been the subject of almost continuous debate for more than two decades (e.g., Hardwood and Webb, 1998; Stroeven et al., 1998). A key question is whether relatively short warm intervals can cause a loss in ice sheet volume once a stable ice sheet is thought to be in place (i.e., since the middlelate Miocene). The marine oxygen isotope record suggests warming in the earliest Pliocene, culminating at $\sim 3$ Ma during the mid-Pliocene climate optimum (e.g., Kennett and Hodell, 1995; Zachos et al., 2001, 2008; Lisiecki and Raymo, 2005). Marine sediments exposed on land show evidence for a dynamic ice sheet during the late Miocene-early Pliocene as well as for early Pliocene warming. The marine record from drilling in Prydz Bay, the Ross Sea, and the Antarctic Peninsula also shows evidence for repeated advances and retreats of the Antarctic ice sheet during the late Miocene and early Pliocene. For example, the silicoflagellate assemblages at Site 1165 in Prydz Bay pinpoint three intervals within the Pliocene (3.7, 4.3-4.4, and 4.6-4.8 Ma) with sea-surface temperatures in the Southern Ocean roughly $5^{\circ} \mathrm{C}$ warmer than today (Whitehead and Bohaty, 2003). In the Antarctic Peninsula, a strong decrease in sea ice cover starting at $5.3 \mathrm{Ma}$ and maintained during the early Pliocene is indicated by opal deposition (Grützner et al., 2005; Hillenbrand and Ehrmann, 2005). Diatom stratigraphic analyses in these sediments show three warming events between 3.5 and $3.7 \mathrm{Ma}$, which also can be recognized in cores from the Antarctic Peninsula and Prydz Bay, implying that these events were of continent-wide significance (Escutia et al., 2009).

Indirect evidence (i.e., sea level changes and ocean floor sediments) also suggests that ice volume during the Pliocene was subject to cyclical variability. Because Northern Hemisphere ice sheets were not fully developed, it is thought that sea level changes were driven by fluctuations of the Antarctic ice sheet. Many scientists believe that the WAIS, grounded below sea level and thus thought to be less stable, was responsible for these changes. The role of the much larger and presumed more stable EAIS remains controversial. The timing of the transition of the EAIS from a polythermal dynamic condition to a predominantly cold stable state is critical to this argument. The eastern Wilkes Land margin receives sediment delivered through the Wilkes subglacial basin (Figs. F4, F5) where the EAIS is partly grounded below sea level and thus may have been more sensitive to climate changes in the late Neogene. The record of ice sheet fluctuations during the times that the EAIS is thought to be more stable (after $15 \mathrm{Ma}-$ Holocene) is 
critical for developing reliable models of ice sheet behavior, which may be the basis for future predictions of Antarctic ice sheet stability in response to global climate change.

\section{Ultrahigh resolution Holocene record}

The nature, range, and rates of Holocene climate change remain critical research targets, as this information defines the background variability against which we assess anthropogenic change. Because atmospheric $\mathrm{pCO}_{2}$ levels vary by $<8 \%$ during most of the Holocene, this interval also provides a means of assessing the influence of other climate change forcing factors (solar, ocean-atmosphere interaction, and volcanic). Holocene records are rare from the Antarctic, yet the phenomenon of polar amplification combined with evidence for significant Holocene variability in the mid-latitudes of the Southern Hemisphere (Gilli et al., 2005; Lamy et al., 2001; Theissen et al., 2008; Baker et al., 2001; and many others) suggests the signal may be large. The absence of ice advance over the Antarctic continental shelf during the Holocene means that rapidly accumulating sediments are preserved, whereas the sediment records of previous interglacials have mostly been removed by glacial erosion. Site U1357 contains nearly $200 \mathrm{~m}$ of laminated, presumably varved, Holocene diatomaceous sediments. If continuously (or nearly so) varved, it will be the first of its kind from the Antarctic margin. This will allow analysis of changes in wind regime, water temperature, and sea ice conditions at annual to decadal timescales and permit correlation to rapidly accumulating ice-core records from Antarctica's coastal ice domes.

A continuous Holocene section from the Australian sector of the East Antarctic margin will also provide a comparison to existing Pacific Ocean records, such as those from the Palmer Deep (Antarctic Peninsula, ODP Leg 178) and Ross Sea. In particular, we note that modern East Antarctic margin climate is not strongly influenced by ENSO, as is the case for the Antarctic Peninsula (Domack et al., 1993, 2001, 2003, 2005; Shevenell et al., 1996; Shevenell and Kennett, 2002; Leventer et al., 1996, 2002; Domack and Mayewski, 1999) and Ross Sea (Leventer and Dunbar, 1988; Leventer et al., 1993; Cunningham et al., 1999; Domack et al., 1999). Rather, this region responds to variability in the SAM, drainage from the EAIS, and the relative strength of the polar easterlies. Variability in these signals over interannual to millennial timescales needs to be established if we are to understand how forcing factors such as solar variability, ocean-atmosphere interactions, orbital parameters, and volcanic activity influence climate and oceanographic processes in the Southern Ocean.
Development of high-quality, high-resolution Holocene climate records from the East Antarctic margin is a necessary step toward understanding the circumAntarctic response to climate forcing and addressing similarities, differences, and possible links to the global record (i.e., as in Domack and Mayewski, 1999). These data will help us evaluate the response of the EAIS and margin to global warming. Scientific questions specific to the Adélie Drift drilling are

1. What was the response of the East Antarctic margin glacial system to global and regional Holocene climate fluctuations? Was the response similar to and/or synchronous with marine records obtained from the Antarctic Peninsula and Ross Sea?

2. Was East Antarctica substantially influenced by solar cycle variability? Are the 90, 200, and $400 \mathrm{y}$ cycles of paleoproductivity and sea ice extent, as seen in the Palmer Deep, recorded here as well?

3. How do global climatic events such as the Little Ice Age, Holocene climatic optimum, and Younger Dryas affect the East Antarctic margin? More broadly, does the paleoclimatic record from the East Antarctic margin demonstrate synchronicity with Northern Hemisphere records (see Domack and Mayewski, 1999) and, during deglaciation, with other parts of the Antarctic margin (Siegert et al., 2008)?

4. With annual resolution through at least part of the Holocene, can we observe clear interannual variability in the sea ice extent and/or wind regime (an established fact at the Palmer long-term ecological research location in the Antarctic Peninsula, where this is linked to ENSO) and what does this tell us about the recent trend toward great sea ice extent in East Antarctica (Zhang, 2007; Turner et al., 2009)?

5. How is the SAM modulated through time?

If sufficient benthic signal carriers are present, we can address questions about Holocene variability in Antarctic Bottom Water (AABW) production along the Wilkes Land margin (current estimates are that as much as $25 \%$ of all AABW may be generated in the nearby Mertz polynya) (Rintoul, 1998; Marsland et al., 2004; Williams et al., 2008).

\section{Additional objectives}

Wilkes Land margin cores will help assess the main controls on sediment transport and deposition on ice-dominated continental shelves and rises in order to test present architectural models of glacial processes and facies for high-latitude margins. Efforts will be made to understand the controlling factors in continental rise deposition in order to make more informed interpretations about their significance in terms of Antarctica's glacial evolution. For example, 
how does ice sheet development and evolution influence or control the development of the large mounded deposits (i.e., as much as $700 \mathrm{~m}$ relief) and large upper-fan channel-levee complexes (i.e., $900 \mathrm{~m}$ relief) on the continental rise? What factors produced the shift in depocenters landward causing a decrease in sediment supply to the continental rise deposits? In these mixed turbidite and contourite systems, how we can differentiate the gravity flow depositional signal of glacial advances and retreats from the paleoceanographic signal represented in the bottom contour-current deposits? Finally, tying biostratigraphic datums to the geomagnetic polarity timescale (GPTS) has been notoriously difficult at high southerly latitudes. Cores obtained from the Wilkes Land expedition will provide the opportunity to improve the magnetostratigraphic calibration for the biostratigraphic zonations.

\section{Site summaries}

\section{Site U1355}

The primary objective at Site U1355 (proposed Site WLRIS-06A) was to core across unconformity WL-U3 to obtain the timing and nature of the first arrival of the ice sheet to the Wilkes Land Continental Margin in a distal setting. Site U1355 is at the transition between the continental rise and the abyssal plain in a water depth of 3723 mbsl (Fig. F13; Table T1).

Multichannel seismic reflection profiles crossing Site U1355 (Fig. F14) image three of the Wilkes Land margin regional unconformities (WL-U3, WL-U4, and WL-U5). Unconformity WL-U3 is observed between $\sim 782$ and 825 mbsf (5.95 ms two-way traveltime [TWT]) and was interpreted to separate preglacial strata below from glacial strata above. Thus, coring across unconformity WL-U3 was intended to document the first arrival of the ice sheet to the Wilkes Land Continental Margin. This "onset" of glaciation is presently inferred to have occurred during the earliest Oligocene.

Site U1355 was also chosen to provide a distal record of Oligocene-Pliocene(?) glacial-interglacial (i.e., colder versus warmer) and ice sheet variability. Regional unconformity WL-U5 is imaged in the seismic data at 709 mbsf (5.6 s TWT) (Fig. F14). Unconformity WL-U5 represents a major shift in continental rise sedimentation with the onset of thick levee deposits above the unconformity. Coring across unconformity WL-U5 aimed to document the timing, nature, and cause of this shift in sedimentation.

Guided by the regional seismic interpretations, Site U1355 is where the uppermost sedimentary section is relatively thin, or has been eroded, so that uncon- formity WL-U3 could be reached at a shallower depth in contrast to other locations offshore the Wilkes Land margin.

Based on the seismic facies at Site U1355, the lithologies expected were fine-grained distal turbidites, contourites, and hemipelagites (Escutia et al., 1997, 2000, 2002; De Santis et al., 2003; Donda et al., 2003). This interpretation was supported by the sediments recovered from DSDP Leg 28 Site 269 (Hayes, Frakes, et al., 1975) located on the abyssal plain $\sim 280 \mathrm{~km}$ seaward from Site U1355.

Four cores from one hole were obtained at Site U1355. Cores 318-U1355A-1R through 4R penetrated from 0 to $31.7 \mathrm{mbsf}$ and recovered $14.95 \mathrm{~m}$ (47\%). The stratigraphic integrity of most of the core was highly compromised by drilling disturbance. The sediments are composed of angular igneous and metamorphic fragments. These fragments are unconsolidated, clast-supported, moderately to well-sorted sandy granule-pebble conglomerates grading upward into well-sorted, fine, crudely stratified sands. One $3 \mathrm{~cm}$ thick interbed of dark greenish gray diatom-bearing silty clay was preserved between two upward-fining units. The mechanism for the formation of the upward-fining beds is through gravity flow, most likely a high-density turbidity current.

Samples from Hole U1355A were analyzed for siliceous microfossils, foraminifers, and palynomorphs. Core catcher samples from Cores 318-U1355A-1R through $4 \mathrm{R}$ and additional samples from clay-rich clasts within the cores were analyzed for diatoms. The core material yielded an abundant Antarctic flora dominated by Fragilariopsis kerguelensis and Thalassiosira lentiginosa. The association of these typical Pleistocene-Holocene Antarctic diatoms along with common Actinocyclus ingens and A. ingens var. ovalis indicates an age no older than late Pleistocene. Reworking from Miocene and Eocene material was recorded. A sample from the top of the hole yielded a rich and diverse modern (Holocene) Antarctic diatom assemblage. Radiolarians typical of late PleistoceneHolocene Antarctic waters were also found in the core catchers and seafloor samples with an overall low abundance. The seafloor sample yielded a lowdiversity planktonic foraminifer assemblage dominated by Neogloboquadrina pachyderma, indicating an age <9.2 Ma. Palynomorphs were recorded in the seafloor sample and Samples 318-U1355A-1R-CC and 4R-CC. Notable finds included Holocene organicwalled dinocysts, foraminifer linings, copepod eggs, reworked late Eocene dinocysts, and reworked Paleogene and/or Cretaceous spores and pollen.

The physical property program for Hole U1355A cores included nondestructive measurements of gamma ray attenuation (GRA) densitometer bulk density, magnetic 
susceptibility, natural gamma ray (NGR) emission, and $P$-wave velocity on whole-round core sections. Whole-round and section-half core logging measurements are significantly affected by poor core quality, and the data are therefore compromised. Magnetic susceptibility values are relatively high, reflecting the lithologic composition of the individual clasts in the gravels and sands. The silty diatom-bearing clay clasts are characterized by pronounced lower magnetic susceptibility, bulk density, and sonic velocity values but higher NGR counts. $P$-wave velocities increase from $1800 \mathrm{~m} / \mathrm{s}$ at the seafloor to $>1920 \mathrm{~m} / \mathrm{s}$ at the base of Core 318-U1355A-2R.

In summary, operations at Site U1355 revealed that the nature of the seafloor was not the expected finegrained sediments. After failing to core into the seafloor with the advanced piston corer (APC), the rotary core barrel (RCB) system was tried (see "Operations" in the "Site U1355" chapter) and yielded $31.7 \mathrm{~m}$ of Pleistocene-Holocene unconsolidated coarse gravels and sands. The unconsolidated and coarse-grained nature of the sediment prevented any further advance. We decided to abandon Hole U1355A and move to Site U1356, where we could achieve the same scientific objectives.

\section{Site U1356}

Site U1356 (proposed Site WLRIS-07A) is located at the transition between the continental rise and the abyssal plain at 3992 mbsl (Fig. F15; Table T1). The main objective at Site U1356 was to core across regional unconformity WL-U3 to obtain the timing and nature of the first arrival of the ice sheet to the Wilkes Land Continental Margin in a distal setting.

Similar to Site U1355, three regional unconformities reported from the Wilkes Land margin (unconformities WL-U3, WL-U4, and WL-U5) are imaged at Site U1356 (Fig. F16). Unconformity WL-U3, interpreted to separate preglacial strata below from glacial strata above and presently inferred to have formed during the earliest Oligocene, occurs at $\sim 867 \mathrm{mbsf}$ (6.33 s TWT). Unconformities WL-U4 and WL-U5 are imaged at $\sim 708$ and 534 mbsf (6.15 and 5.95 s TWT), respectively, based on assumed velocities (Fig. F16). Coring across unconformities WL-U4 and WL-U5 was to provide a distal early Oligocene-(?)Pliocene record of glacial-interglacial (i.e., colder versus warmer) and ice sheet and sea ice variability. Multichannel seismic reflection profiles crossing Site U1356 indicated that the site would penetrate a thick sequence of stacked levee deposits developed between two deep-sea channels and above unconformity WL-U4 (Fig. F16). Based on their geometry and seismic facies associations, these levee deposits are interpreted to form when high volumes of sediment were delivered to the continental shelf edge by a wet-based EAIS (Escutia et al., 2000). Reworking of turbidite deposits by bottom-water currents was also suspected based on the presence of wavy reflectors (Escutia et al., 2000, 2002; Donda et al., 2003). Drilling at Site U1356, therefore, would examine the earlier stages of development of large sediment levees denoted by unconformity WL-U5 in addition to the drivers for this change. Below the levee deposits and closely coinciding with unconformity WL-U4, strata are characterized by horizontal and continuous reflectors of varied amplitude that are interpreted to represent hemipelagic and distal turbidite and contourite sedimentation, based on comparisons with sediments recovered at Leg 28 Site 269 (Hayes, Frakes, et al., 1975).

Hole U1356A was cored to 1006.4 mbsf. The dominant lithofacies are moderately to strongly bioturbated claystone and calcareous claystone with Zoophycos or Nereites ichnofacies. Subordinate lithofacies include laminated silty claystones, diamictites, mudstones and sandstones with dispersed to common clasts, and graded or cross-laminated siltstones and sandstones. These facies associations are interpreted to result from hemipelagic sedimentation with variable bottom current and gravity flow influence. Wavy submillimeter-thick black concretions observed below $\sim 373 \mathrm{mbsf}$ are interpreted as a form of silica diagenesis. Carbonate-cemented sandstones and conglomerates are also present below this depth.

The sedimentary section is divided into 11 lithostratigraphic units (Fig. F3 in the "Site U1356" chapter).

- Units I and II (0-278.4 mbsf) are composed of diatom oozes and diatom-rich silty clays with dispersed gravel indicating hemipelagic sedimentation with ice rafting.

- Units III (278.4-459.4 mbsf), V (593.8-694.4 mbsf), and VII (723.5-782.7 mbsf) are characterized as repetitively interbedded light greenish gray bioturbated claystones and brown laminated claystones with cross-laminated siltstone and sandstone interbeds. These units are interpreted to indicate cyclical changes in bottom oxygenation, current strength, and fine-grained terrigenous sediment supply. Gravel-sized clasts are rare in these units, and only minimal evidence for ice rafting from rare dispersed sand grains is present.

- Units IV (459.4-593.8 mbsf) and VI (694.4$723.5 \mathrm{mbsf}$ ) are characterized by extensive interbeds of contorted diamictites and other gravel-bearing lithologies, indicating a strong gravity flow influence.

- Units VIII (782.7-879.7 mbsf) and IX (879.7$895.5 \mathrm{mbsf}$ ) are composed of mudstones with extensive contorted and convolute bedding. 
- Unit X (895.5-948.8 mbsf) is composed of crudely stratified and graded sandstones. These units are affected by several types of mass transport, including submarine slides and slumps.

- Unit XI (948.8-1006.4 mbsf) is characterized by bioturbated claystones with subordinate stratified siltstone and sandstone, indicating hemipelagic sedimentation with minor bottom current and gravity flow influence.

- Units IX, X, and XI (below $~ 880$ mbsf) have a clay mineral assemblage dominated by smectite and kaolinite, indicating chemical weathering under relatively warm and humid conditions. This clay mineral assemblage is distinctly different from that of the overlying units (above $\sim 880 \mathrm{mbsf}$ ), where the dominant clay minerals are illite and chlorite, indicative of physical weathering in a glacially influenced environment.

Siliceous microfossils (diatoms and radiolarians), calcareous nannofossils, and organic-walled dinoflagellates (dinocysts) are the primary source of microfossil-based age control for Hole U1356A (Fig. F4 in the "Site U1356" chapter). The different microfossil groups resolve the stratigraphy nearly exclusive of one another by depth. Diatoms provide a high-resolution stratigraphy for the uppermost lower Miocene to the lowermost Pliocene drape (the upper $387 \mathrm{mbsf}$ ). Calcareous nannofossils and, to a lesser extent, dinocysts resolve the Oligocene interval between $\sim 434.5$ and $\sim 875.12$ mbsf. Dinocysts provide the only microfossil age control for the lowermost Oligocene and the Eocene ( 895.5 and $\sim 995.32 \mathrm{mbsf})$. Radiolarians and planktonic foraminifers provide secondary age control, which is in agreement with the other fossil groups.

Diatoms and radiolarians suggest that the Pleistocene and all but the lowermost Pliocene (i.e., 0 to $\sim 4.2 \mathrm{Ma}$ ) are missing from Hole U1356A and that at least two other major hiatuses are centered around 4.6 and 28.38 mbsf. This indicates that much of the upper Miocene is also missing. A break in sedimentation near the Oligocene-Miocene transition is suggested by foraminifers and nannofossils. The duration of this hiatus is $\sim 6 \mathrm{~m} . \mathrm{y}$., between 23.12 and $17.2 \mathrm{Ma}$, with most of the early Miocene missing. A relatively thick ( $400 \mathrm{~m})$ Oligocene sequence is constrained by magnetostratigraphy and partially by dinocyst and nannofossil data. The very lowermost Oligocene, the upper Eocene, and most of the middle Eocene are missing in a long hiatus from 47.9 to $33.6 \mathrm{Ma}$ based on dinocyst evidence. The oldest break in sedimentation occurs in lower Eocene strata between Sample 318-U1356A-100R-1, $100 \mathrm{~cm}$, and 101R-1, $100 \mathrm{~cm}$ (940.10-949.80 mbsf). Paleomagnetostratigraphy and dinocyst stratigraphy indicate this hiatus spans from 51.90 to $51.06 \mathrm{Ma}$, practically coinciding with the boundaries between lithostratigraphic Units $\mathrm{X}$ and XI at 948.8 mbsf.

Three intervals with continuous enough recovery and sufficient biostratigraphic data establish a correlation to the GPTS (Table T1 in the "Site U1356" chapter). Cores 318-U1356A-14R through 51R appear to correlate to polarity Chrons C5AAn to C5Cn.3n. A mid-Miocene hiatus could be placed just above Core 46R because the polarity stratigraphy from Cores 46R through 51R does not have a straightforward fit to Chrons 5Dn and below. Cores 68R through 92R correlate to polarity Chrons C7An$\mathrm{C} 12 \mathrm{R}$. The lowermost normal polarity interval in Core 105R and the top part of 106R corresponds to Chron C24n.3n based on biostratigraphic evidence. Core $104 \mathrm{R}$ is dominantly reverse polarity with a short normal polarity interval correlating to Chron C24n.2n, also based on biostratigraphic data. The top of Core 104R and all of 103R record Chron C24n.1n. Whereas Core 102R has reverse polarity and fits within Chron C23r, Core 101R could record the base of Chron 23n.2n. The correlation of Cores $100 \mathrm{R}$ and $99 \mathrm{R}$ is not straightforward because they mostly have reverse polarity, whereas Chron C23n.2n is of normal polarity. Because the transition recorded in Core $101 \mathrm{R}$ and correlation to Chron C23n.2n fits with a constant sediment accumulation-rate model extrapolating upward from the Chron C24n tie points, the hiatus is most likely positioned between Cores 101R and 100R. The smallest gap would place the transition recorded in Core 99R at the base of Chron C23.1n with Core 100R being Chron C23r in age, with a sliver of Chron C23.2n at its base (interval 318-U1356A-101R-1, $100 \mathrm{~cm}$ ). This magnetostratigraphic interpretation matches the dinocyst stratigraphy and the lithostratigraphy.

Carbonate contents for most of the section are below 2 wt $\%$, and levels of organic carbon, sulfur, and nitrogen are below detection limits. Major and trace elements $\left(\mathrm{SiO}_{2}, \mathrm{Al}_{2} \mathrm{O}_{3}, \mathrm{TiO}_{2}, \mathrm{~K}_{2} \mathrm{O}, \mathrm{Na}_{2} \mathrm{O}, \mathrm{MgO}, \mathrm{Fe}_{2} \mathrm{O}_{3}\right.$, $\mathrm{P}_{2} \mathrm{O}_{5}, \mathrm{Sr}, \mathrm{Ba}, \mathrm{Sc}, \mathrm{Co}$, and $\mathrm{V}$ ) show pronounced downcore variations, which can be summarized in three geochemical intervals:

1. An upper interval from 0 to 878 mbsf where all elements show minor fluctuations, reflecting elemental association with biogenic and physically weathered terrigenous phases;

2. A transitional interval from 878 to $920 \mathrm{mbsf}$ where all elemental concentrations show significant changes in their absolute values; and

3. A lower interval from 920 to 1000 mbsf where most elements show characteristics of highly weathered terrigenous material.

Physical properties generally change at the identified lithostratigraphic boundaries at Site U1356. Velocity, 
density, and porosity data clearly reflect the positions of features such as unconformities WL-U5 and WL-U3. The grain density increases from $\sim 2.6 \mathrm{~g} / \mathrm{cm}^{3}$ at the seafloor to $\sim 2.8 \mathrm{~g} / \mathrm{cm}^{3}$ at $1000 \mathrm{mbsf}$. Magnetic susceptibility data exhibit rhythmic changes, which are especially visible in the cores with improved recovery starting at Core 318-U1356A-47R and moreso from Core 68R downward.

\section{Site U1357}

The primary objective at Site U1357 (proposed Site ADEL-01B) was to recover a continuous $\sim 200 \mathrm{~m}$ Holocene sedimentary section from the Adélie Basin located on the Antarctic continental shelf off the Wilkes Land margin. The Adélie Basin is a $1000 \mathrm{~m}$ deep glacially scoured trough separated from the Adélie Depression (70 km eastward) by the $200 \mathrm{~m}$ deep Adélie Bank (Figs. F9, F10). Previous piston and kasten coring of the upper sediment column shows that sediments in the Adélie Basin are deposited as annual to near-annual layers averaging $2 \mathrm{~cm}$ in thickness. The thickness of the Holocene sedimentary section above the last glacial diamict $(190 \mathrm{~m}$; Fig. F11) is consistent with this high rate of sedimentation being maintained for the past $10,000 \mathrm{y}$.

The ultrahigh resolution Adélie Basin Holocene section will be used to attempt to produce the first annually resolved time series of oceanographic and climatic variability derived from a Southern Ocean marine sediment core. These data can be directly compared to annual ice-core records from Antarctica's coastal ice domes as well as other marine sediment cores from the Antarctic Peninsula and other parts of the East Antarctic margin. The site is sensitive to drainage winds from Antarctica as well as the polar easterly winds, sea ice extent, the Southern Annual Mode, and the position of the southern boundary of the Antarctic Polar Frontal Zone in the Indian and Pacific oceans. Little is known about past variability in these systems from marine records, and none have annual or near-annual resolution. The Adélie Basin site lies directly downwind and downcurrent from the Mertz Glacier polynya (Massom et al., 2001, 2003) and therefore collects biogenic materials produced in one of Antarctica's major coastal polynyas. The Mertz Glacier polynya and underlying Adélie Depression may produce as much as $25 \%$ of all AABW (Rintoul, 1998; Marsland et al., 2004; Williams et al., 2008). Given the known presence of benthic foraminifers in the Adélie Basin and the substantial bottom water temperature anomaly associated with local high-salinity shelf water, Site U1357 has the potential to yield information on AABW production through time. Understanding Holocene climate variability at this East Antarctic site will aid in determining the range and characteristics of natural climate variability during a period of relatively constant atmospheric carbon dioxide levels. This record will also aid in the assessment of different forcing factors (solar, ocean-atmosphere interaction, and volcanic) responsible for climate change over the past $10,000 \mathrm{y}$.

Sediments accumulate in the $1000 \mathrm{~m}$ deep Adélie Basin (Figs. F9, F10) as a thick drape overlying a high-amplitude reflector with no underlying penetration (Fig. F11). The strong reflector is interpreted as a glacial diamict from the Last Glacial Maximum. The EAIS expanded to the shelf edge during the Last Glacial Maximum (Domack, 1982; Barnes, 1987; Eittreim et al., 1995), and the Adélie Basin was filled with ice. Ice lift-off and southward retreat from other deep shelf basins of East Antarctica occurred between 10,000 and 11,000 y ago (Siegert et al., 2008; Leventer et al., 2006). This is the expected age range of the lowermost sediments recovered from Site U1357. The seismic line shows $190 \mathrm{~m}$ of continuous, horizontal, parallel reflectors at the site, consistent with a drape of Holocene sediment undisturbed by sea level change or glacial erosion.

Three holes were cored at Site U1357. In Hole U1357A, Cores 318-U1357A-1H through 21X penetrated to $186.6 \mathrm{mbsf}$, recovered $183.87 \mathrm{~m}(99 \%)$ of diatomaceous ooze, and penetrated the underlying last glacial diamict. After offsetting the ship $50 \mathrm{~m}$ east of Hole U1357A, we cored Hole U1357B. Cores 318U1357B-1H through $19 \mathrm{H}$ penetrated to $170.7 \mathrm{mbsf}$ and recovered $172.44 \mathrm{~m}(101 \%)$ of sediment. Hole U1357C, offset $25 \mathrm{~m}$ west of Hole U1357A, produced Cores $318-\mathrm{U} 1357 \mathrm{C}-1 \mathrm{H}$ through $11 \mathrm{H}$, penetrated to $103.8 \mathrm{mbsf}$, and recovered $110.7 \mathrm{~m}$ (107\%) of sediment. Cores from Hole U1357A were split and described during the expedition. Cores from Holes U1357B and $\mathrm{U} 1357 \mathrm{C}$ were preserved as whole-round sections for postcruise splitting, describing, and sampling. All cores from this site contained sediments that vigorously degassed methane and hydrogen sulfide upon decompression to 1 atmosphere (see "Geochemistry and microbiology" in the "Site U1357" chapter). Gas pressure caused expansion of the sediment section, which resulted in the loss of some sediment from core breaks as well as section breaks, particularly above $40 \mathrm{mbsf}$. This was minimized by drilling small holes in the core liners at regular intervals.

The sediments in Hole U1357A consist of three lithologic units (see "Lithostratigraphy" in the "Site U1357" chapter). The uppermost Unit I is $170 \mathrm{~m}$ of laminated Holocene diatom ooze. Unit I overlies a $15 \mathrm{~m}$ transitional unit of sand and silt-bearing diatom ooze (Unit II), which in turn sits on a hard, carbonatecemented, and poorly sorted gravelly siltstone (Unit 
III, a diamict). Units I and II exhibit regular laminations defined by color (alternating dark olive-brown to light greenish brown layers) and textural variability. Individual laminations range in thickness from 1 to $3 \mathrm{~cm}$ and extend throughout the entire $186 \mathrm{~m}$ thick section lying on top of the diamict.

Based on analysis of multiple samples from core breaks and section breaks, Site U1357 sediments contain a well-preserved Holocene Southern Ocean diatom flora with varying contributions from cool open-ocean and sea ice-associated taxa (Armand et al., 2005; Crosta et al., 2005a). Radiolarians, silicoflagellates, and sponge spicules are common and well preserved. Organic-walled dinocysts are present as well as motile dinoflagellate stages, abundant tintinnid loricae, and copepod remains.

Light and dark laminations were sampled throughout the Holocene section. Based on trends in diatom assemblage succession within paired laminations as well as previous work from the Adélie Basin region (Denis et al., 2006) and other laminated diatom sections from the east Antarctic margin (e.g., Stickley et al., 2005; Maddison et al., 2006), each light-dark lamination couplet is provisionally interpreted as a single season of biogenic production and accumulation. It is assumed that diatomaceous sediments begin to accumulate during spring sea ice retreat following the development of early season phytoplankton blooms in the Mertz Glacier polynya. Blooms persist through summer open-water conditions and conclude with the autumn regrowth of sea ice and destabilization of the water column. The unusually high accumulation rates (averaging $2 \mathrm{~cm} / \mathrm{y}$ ) are likely the result of syndepositional focusing processes that sweep biogenic debris from the shallow Adélie and Mertz banks into the deep shelf troughs of the Adélie Basin and Adélie Depression.

A low-diversity assemblage of calcareous planktonic (N. pachyderma and Globigerina bulliodes) and benthic foraminifers (Globocassidulina subglobosa and Triloculina frigida) occurs in Site U1357 Holocene sediments. Planktonic foraminifers were observed throughout the sedimentary section, and benthic foraminifers were observed in several core-break samples that were sieved. The occurrence of well-preserved calcareous foraminifers is unusual in Antarctic shelf basins, as shelf bottom waters are highly undersaturated with respect to calcite. High sedimentation rates likely contribute to foraminifer preservation in the Adélie Basin sediments.

In addition to abundant diatoms and foraminifers, sediments in Hole U1357A contain large quantities of fish debris, including at least 44 layers of concentrated fish vertebrae. With abundant phosphatic, calcareous, opaline, and organic biogenic detritus, Site
U1357 sediments offer an unusually diverse array of assemblage-based and geochemical environmental tracers for shore-based studies.

Site U1357 sediments posed a significant challenge for the analysis of physical properties (see "Physical properties" in the "Site U1357" chapter). The sediments are so diatomaceous that they exhibit extremely low to negative magnetic susceptibility. Whole-round core analysis of all three holes using a Bartington loop sensor and split-core analysis using a point source magnetic susceptibility sensor in Hole U1357A did not yield useful data for hole to hole correlation. The production of millimeter-scale pockmarks from degassing of methane and hydrogen sulfide throughout the sediment column makes bulk density determination difficult using discrete sample analysis (moisture and density) or with the GRA densitometer. Natural gamma ray levels are minimal because of the low concentration of terrigenous material in lithostratigraphic Unit I. Nevertheless, with sufficient background count correction NGR track scans yielded useful data for the correlation of cores from Holes U1357B and U1357C and a portion of cores from Hole U1357A.

Additional information for attempting hole to hole correlation was provided by magnetic susceptibility determination of $>1800$ discrete samples that had been taken from Hole U1357A at $10 \mathrm{~cm}$ intervals for postcruise foraminifer analysis. Each dried sample was weighed and analyzed with the Kappabridge KLY magnetic susceptibility detector. The Kappabridge has roughly 2 orders of magnitude greater sensitivity than the whole-core loop or split-core point source sensors. The resulting data set suggests that magnetic susceptibility measurements of discrete samples might be of use in developing a robust hole to hole correlation.

Site U1357A is located close to the south magnetic pole, and we observed the expected high inclinations in the paleomagnetic signature of split-core sections (see "Paleomagnetism" in the "Site U1357" chapter). After processing and matching paleomagnetic declinations across core breaks, Hole U1357A yielded a paleomagnetic secular variability profile that appears to match a geomagnetic secular variation model spanning the last 7000 y (CALS7k.2 of Korte and Constable, 2005) for $66^{\circ} \mathrm{S}, 144^{\circ} \mathrm{E}$. The agedepth relationship predicted by application of this model to the secular variation signal obtained from Hole U1357A is consistent with that expected for this site based on radiocarbon dating of the upper $50 \mathrm{~m}$ of the sediment column (Costa et al., 2007) and the overall sediment sequence thickness.

Geochemical analysis of 96 sediment samples from Hole U1357A (see "Geochemistry and microbiology" 
in the "Site U1357" chapter) yielded $\mathrm{CaCO}_{3}$ contents ranging from 1 to $3 \mathrm{wt} \%$ for most of the hole, with one distinct carbonate-rich layer $\left(\mathrm{CaCO}_{3}>9 \mathrm{wt} \%\right)$ at 126.34 mbsf. Organic $\mathrm{C}$ content is uniformly high (for Antarctic shelf sediments), between 1 and $2 \mathrm{wt} \%$. C/N ratios between 7 and 12 are consistent with relatively well preserved and labile marine organic matter. $\mathrm{SiO}_{2}$ concentrations are high (76-91 wt \%) and are accompanied by low concentrations of $\mathrm{TiO}_{2}(<0.3 \mathrm{wt} \%)$ and $\mathrm{Al}_{2} \mathrm{O}_{3}(<5.6 \mathrm{wt} \%)$, as expected for a nearly pure diatom ooze with little terrigenous input. The authigenic phosphate mineral struvite $\left(\mathrm{NH}_{4} \mathrm{MgPO}_{4} \cdot 6 \mathrm{H}_{2} \mathrm{O}\right)$, which forms through bacterial biomineralization in anoxic sediments in the presence of ammonium, was observed at several depths.

Headspace methane concentrations varied by more than an order of magnitude downcore, increasing from 5,000 to 43,000 ppm from 0 to $20 \mathrm{mbsf}$ and then declining to highly variable concentrations at greater depths, mostly between 5,000 and 18,000 ppm. Significant concentrations of $\mathrm{H}_{2} \mathrm{~S}$ were detected as well, consistent with anoxic diagenesis of organicrich sediments. An extensive microbiology program, focusing on phospholipid analyses and molecular 16S rRNA sequencing, was completed in the upper $20 \mathrm{~m}$ of Hole U1357C. Pore water samples collected from adjacent whole-round core samples show no detectable $\mathrm{SO}_{4}{ }^{2-}$ except in core top samples suspected of contamination with seawater. Ammonium increases almost linearly from near-surface values of 900 to $4500 \mu \mathrm{M}$ at $18 \mathrm{mbsf}$. Total dissolved inorganic carbon and alkalinity increase to $18 \mathrm{mbsf}$ as well, to values of 79.6 and $88 \mathrm{mM}$, respectively, whereas $\mathrm{pH}$ drops to 7.5 at 20 mbsf. These profiles are consistent with bacterially mediated diagenesis within anoxic pore waters. Methane is derived from $\mathrm{CO}_{2}$ reduction following the removal of $\mathrm{SO}_{4}{ }^{2-}$. Pore waters were not analyzed deeper than $20 \mathrm{mbsf}$ in the core, but samples for 16S rRNA sequencing were taken from core ends to the maximum depth of penetration in Hole U1357C (103.8 mbsf).

\section{Site U1358}

Site U1358 (proposed Site WLSHE-08A) is on the continental shelf off the Adélie Coast at $501 \mathrm{mbsl}$ (Fig. F17; Table T1). The main objective at Site U1358 was to core across regional unconformity WLU8. This unconformity marks a distinct change in the geometry of the progradational wedge from lowdipping strata below to steeply dipping foresets above (Eittreim et al., 1995; Escutia et al., 1997; De Santis et al., 2003) (Fig. F18). This is inferred to represent a significant change from intermittent glaciers to persistent oscillating ice sheets, either during the late Miocene (Escutia et al., 2005; Cooper et al.,
2009 ) or during the late Pliocene ( $3 \mathrm{Ma})$ (Rebesco et al., 2006). The steep foresets above unconformity WL-U8 are thought to likely consist of ice proximal (i.e., till, diamictite, and debris flows) and openwater sediments deposited as grounded ice sheets extended intermittently onto the outer shelf, similar to sediments recovered at Site 1167 on the Prydz Bay Trough fan (O'Brien, Cooper, Richter, et al., 2001; Passchier et al., 2003).

Site U1358 lies at the westernmost edge of the Mertz Bank (Fig. F17) and receives drainage from the EAIS through the Wilkes subglacial basin (Fig. F4). At Site U1358, unconformity WL-U8 occurs at $~ 165$ mbsf (0.84 s TWT) (Fig. F18). Multichannel seismic reflection profiles crossing Site U1358 show gently dipping strata on the shelf that are truncated near the seafloor (Fig. F18). This provided a unique opportunity to sample across the unconformity by drilling at very shallow penetration. The record from Site U1358 will also complement the more distal (i.e., glacial-interglacial cycles) record from Sites U1359 and U1361, located on the continental rise.

We drilled two short holes at Site U1358 in a water depth of 501 mbsl. Unfortunately, we were only able to penetrate to $35.6 \mathrm{mbsf}$ before the drill collars failed and we had to abandon the hole.

Hole U1358A was drilled to a total depth of $2.0 \mathrm{mbsf}$ and Hole U1358B was drilled to a total depth of $35.6 \mathrm{mbsf}$, both using the RCB system. The upper $8.2 \mathrm{~m}$ is unconsolidated and moderately to strongly disturbed by drilling. Below $8.2 \mathrm{mbsf}$, the sediments are consolidated and only slightly disturbed by drilling. Holes U1358A and U1358B penetrated diamictons and diamictites and are placed within a single lithostratigraphic unit (Fig. F3 in the "Site U1358" chapter). The diamictons in the upper $8.2 \mathrm{mbsf}$ were probably deposited from floating ice. The diamictites below 8.2 mbsf were either deposited from floating ice, where crudely stratified and laminated, or subglacially with possible remobilization by glacigenic debris flow.

Sediments in Holes U1358A and U1358B contain siliceous and organic microfossils. Diatom biostratigraphy provides tentative stratigraphic control throughout the section. Pliocene strata $(9.32-28.62 \mathrm{mbsf})$ are overlain by uppermost Pleistocene to Holocene strata. Dinocysts and radiolarians were encountered in trace amounts only and provide no further age constraints. Foraminifers were not encountered in holes drilled at Site U1358. Diatom assemblages suggest a high-nutrient, open-water environmental setting, similar to that of the modern-day Southern Ocean north of the winter sea ice extent. Palynological associations are a mix of reworked and in situ palynomorphs. In situ protoperidinioid dinocysts 
confirm a nutrient-rich environment. High abundances of reworked Mesozoic/Paleozoic microfossils indicate a significant input of eroded sediments.

Whole-core magnetic susceptibility was measured at $2.5 \mathrm{~cm}$ intervals ( $2 \mathrm{~s}$ measurement time). The raw data values range from 3 to 2834 instrument units (Fig. F4 in the "Site U1358" chapter). However, the majority of measurements vary between 200 and 400 instrument units, with some peaks in Core 318-U1358B-4R representing gravel clasts. Variations in GRA density reflect variations in the composition of the PliocenePleistocene diamictite that varies between clast-rich muddy and clast-rich sandy lithologies.

\section{Site U1359}

Site U1359 (proposed Site WLRIS-04A) is located on the continental rise at 3009 mbsl (Fig. F19; Table T1). The main objective at Site U1359 was to obtain an expanded record for the late Neogene to Quaternary to provide a history of climate and paleoceanographic variability and to investigate the stability of the EAIS during the middle Miocene to Pleistocene extreme warm periods (e.g., Miocene climate optimum, early Pliocene, and Pleistocene marine isotope Stages 31 and 11). This record was to also provide the timing and nature of deposition of the upper seismic units (i.e., above unconformity WL-U6) defined on the Wilkes Land margin (De Santis et al., 2003; Donda et al., 2003). These units include a shift in sedimentary depocenters from the continental rise to the outer shelf, possibly corresponding to the transition from a dynamic wet-based EAIS to a more persistent cold-based EAIS (Escutia et al., 2002; De Santis et al., 2003) and inferred to occur during the late Miocene-Pliocene (Escutia et al., 2005; Rebesco et al., 2006). At Site U1359, unconformities WL-U6, WL-U7, and WL-U8 lie at approximately 4.61, 4.44, and $4.23 \mathrm{~s}$ two-way traveltime, respectively (approximately 520, 323, and 126 mbsf, respectively) (Fig. F20).

Site U1359 is located on the eastern levee of the Jussieau submarine channel (Figs. F19, F20). The Jussieau channel is one of the intricate networks of slope canyons that develop downslope into channels and coalescing deep-sea fans (Escutia et al., 2000). Site U1359 is positioned in an upper fan environment where the levee relief (measured from the channel thalweg to the top of the levee) is $\sim 400 \mathrm{~m}$. Multichannel seismic profiles across the site show that widespread channels with high-relief levees occur on the Wilkes Land margin above unconformity WLU5 (Escutia et al., 1997, 2000; Donda et al., 2003). The fine-grained components of the turbidity flows traveling through the channel and hemipelagic drape are inferred to be the dominant sedimentary processes building these large sedimentary levees (Escutia et al., 1997, 2000; Donda et al., 2003). Bottom currents can further influence sedimentation in this setting (Escutia et al., 2002; Donda et al., 2003). Similar depositional systems were drilled during Leg 178 along the Antarctic Peninsula (Barker, Camerlenghi, Acton, et al., 1999) and Leg 188 in Prydz Bay (O'Brien, Cooper, Richter, et al., 2001).

At Site U1359, Holes U1359A-U1359D were drilled to total depths of 193.50, 252.00, 168.70, and 602.2 mbsf, respectively. In Holes U1359A and $\mathrm{U1359B}$, the APC system was used to refusal, followed by extended core barrel (XCB) drilling. Only the APC system was used in Hole U1359C. Hole U1359D was drilled using the RCB system and core was only recovered below 152.2 mbsf. Silty clay with dispersed clasts is the dominant lithology observed throughout all holes at Site U1359. There are noticeable variations in the amount of biogenic components, bioturbation, and sedimentary structures, in particular the presence or absence of packages of siltfine sand laminations and large variations in diatom abundance. Five distinct lithofacies are identified based on variations in the style of lamination, bioturbation, or the relative abundance of the biogenic component. Three lithostratigraphic units are defined on the basis of observed changes in facies associations (Figs. F3, F4 in the "Site U1359" chapter). Lithostratigraphic Unit I (0-42.07 meters composite depth [mcd]) consists of decimeter-scale alternations of yellow-brown and olive-gray diatom-rich silty clays with dispersed clasts with occasional foraminiferbearing clayey silt and sandy silt. Unit II (42.07$264.24 \mathrm{mcd}$ ) consists of bioturbated diatom-bearing silty clays interbedded with olive-gray diatom-bearing silty clays, which are mostly massive but contain decimeter-scale packages of olive-brown silty clay with silt laminations. Unit III extends from $264.24 \mathrm{mcd}$ to the bottom of the cored section at $613.46 \mathrm{mcd}$ and consists of bioturbated diatom-bearing silty clays interbedded with laminated silty clays. The laminated silty clays contain more subtle, but persistent, submillimeter- to millimeter-scale laminations compared to Unit II. Clasts $>2 \mathrm{~mm}$ in size occur throughout all lithostratigraphic units and are mostly dispersed in nature (i.e., trace to $1 \%$ in abundance).

The sedimentology of Units I and II is consistent with levee deposition by low-density turbidity currents, whereas the facies associations in Unit III probably represent deposition in an environment influenced by periodic variations in contour current strength or saline density flows related to bottom water production, with turbidity currents having less influence than in the overlying units. The regular nature of the interbedding (i.e., beds $2-5 \mathrm{~m}$ thick) of the laminated and bioturbated facies within all three 
lithostratigraphic units suggests that the sedimentary record recovered from Site U1359 is cyclic in nature (Figs. F5, F6 in the "Site U1359" chapter). The diatombearing and diatom-rich silty clays (Facies 1 and 2) were probably deposited by hemipelagic sedimentation in a higher productivity environment relative to the other facies. The clays and silty clays (Facies 3-5) indicate high terrigenous sedimentation rates and/or lower biogenic productivity, perhaps related to the duration of seasonal sea ice cover regulating light availability in surface water or wind-regulated control of the mixed layer depth, which in turn controls productivity. The opposite scenario may apply tor the diatom-bearing to diatom-rich silty clay facies (Facies 1 and 2). An increase in terrigenous input may result from ice advance across the shelf or increase in sedimentation from bottom currents. The passage of cold saline density flows related to bottom water production at the Wilkes Land margin (e.g., high-salinity shelf water flowing from the shelf into the deep ocean to form AABW) should also be considered as a potentially important sediment transport mechanism. The depositional model for recovered sediments at Site U1359 may represent a continuum of all three processes, in addition to pelagic and icerafted components, as indicated by the presence of diatom remains and dispersed clasts throughout.

Combined micropaleontology assigns the recovered successions at Site U1359 to the late middle Miocene to late Pleistocene (Fig. F7 in the "Site U1359" chapter). Integrated diatom, radiolarian, foraminifer, and magnetostratigraphic data highlight a late Pliocene to early Pleistocene condensed interval (between $\sim 2.5$ and $1.5 \mathrm{Ma}$ ) and another one during the early late to mid-late Miocene (between $~ 9.8$ and $7 \mathrm{Ma}$ ).

Miocene diatom assemblages mainly include openwater taxa. In addition, a notable increase in the abundance of stephanopyxid specimens may be interpreted as either an indication of shallowing water depths or an increase in reworking of shallower water sediments. The lack of planktonic and benthic foraminifers suggests that bottom waters were corrosive during the late middle Miocene to calcareous foraminifers except for brief periods (e.g., around $\sim 10 \mathrm{Ma}$, when calcareous benthic foraminifers were preserved). Also during the Pliocene, open-water taxa and variable abundances of benthic, neritic, and sea ice-associated taxa dominated diatom assemblages. The dinocyst assemblages predominantly comprise heterotrophic taxa, indicating that the biosiliceous-rich sediments were deposited in a highproductivity and sea ice-influenced setting. High abundances of sporomorphs reworked from Paleogene, Mesozoic, and Paleozoic strata suggest continuous strong erosion in the hinterland. The general lack of planktonic and calcareous benthic foramini- fers suggests that Pliocene bottom waters were corrosive to the thin-shelled tests of planktonic foraminifers. Diatom and radiolarian Pleistocene assemblages at Site U1359 are dominated by typical Neogene Southern Ocean open-water taxa with variable abundances of benthic, neritic, and sea iceassociated diatom taxa. This indicates a pelagic, well-ventilated, nutrient-rich, sea ice-influenced setting, corroborated by the presence of heterotrophicdominated dinocyst assemblages. The preservation of planktonic foraminifers in the Pleistocene indicates that bottom waters were favorable to the preservation of calcium carbonate. Further, pervasive reworked sporomorphs of Paleogene, Mesozoic, and Paleozoic age again point to continuing strong erosion in the hinterland.

Paleomagnetic investigations at Site U1359 involved analysis of discrete samples from Holes U1359A, $\mathrm{U} 1359 \mathrm{~B}$, and U1359D and measurement of archive halves from all four holes. A composite polarity log was correlated to the GPTS of Gradstein et al. (2004), documenting a complete Pliocene section from the top of Chron C2An to the bottom of Chron C3An (Fig. F8 in the "Site U1359" chapter). A gap including Chron Cn2 and a period of extremely slow (and probably discontinuous) sediment accumulation from Chron C3Ar to the top of Chron C5n aligns with the biostratigraphic assessments.

Routine headspace gas analyses were carried out on samples from Holes U1359A-U1359D, and 71 samples were taken for analyses of weight percent carbonate, carbon, nitrogen, and sulfur content, as well as major and trace element analyses. Furthermore, 51 interstitial water samples were taken close to the microbiology samples from the top $20 \mathrm{~m}$ (0.120.1 mbsf) of the holes.

$\mathrm{CaCO}_{3}$ contents for most samples vary between $<1$ and $3.2 \mathrm{wt} \%$. A distinct carbonate-rich layer with a $\mathrm{CaCO}_{3}$ content of $39.7 \mathrm{wt} \%$ was found at 372.45 mbsf and corresponds to a minor lithology of diatom-bearing nannofossil ooze. On the basis of the distribution patterns of the major and trace elements, four broad intervals can be distinguished between 0 and $\sim 200, \sim 210$ and $\sim 310, \sim 310$ and 536, and 547.39 and 594.79 mbsf.

The interstitial water measurements reveal chemical gradients that are consistent with active diagenesis of buried organic matter within the sulfate reduction zone. Significant levels of sulfate at the bottom of the observed profile ( $23 \mathrm{mM}$ at $20.1 \mathrm{mbsf})$ imply that the sampled interval did not reach the carbon dioxide (methanic) reduction zone (see the "Site U1357" chapter for contrasting behavior).

Microbiological sampling was conducted in Hole $\mathrm{U} 1359 \mathrm{~B}$ and was supported with pore water sam- 
pling (Fig. F9 in the "Site U1359" chapter). A total of 52 ten-centimeter whole rounds were taken from the top $20 \mathrm{~m}$ and frozen at $-80^{\circ} \mathrm{C}$ for onshore phospholipid analyses and molecular 16S rRNA sequencing. Between 20 and $200 \mathrm{mbsf}$, seventeen $5 \mathrm{~cm}^{3}$ samples were taken and preserved for onshore molecular $16 \mathrm{~S}$ rRNA sequencing.

The physical property program for Site U1359 includes routine runs on the Whole-Round Multisensor Logger (WRMSL), which includes the GRA bulk density, magnetic susceptibility, and $P$-wave velocity logger (PWL) sensors, as well as NGR measurements. $P$-wave velocity was also analyzed, and samples were taken for moisture, density, and porosity measurements from Holes U1359A, U1359B, and U1359D. Thermal conductivity measurements were taken in cores from all holes. Cyclicities at several scales are observed in the intervals where the magnetic susceptibility ranges between 40 and 100 instrument units. Furthermore, the NGR data together with the magnetic susceptibility and GRA density data were used to correlate the four holes drilled at Site U1359 and to define a composite record (see "Stratigraphic correlation and composite section" in the "Site U1359" chapter). In addition, pronounced lower density values between 50 and 65 mbsf (50 and $65 \mathrm{~m}$ core composite depth below seafloor, method A [CCSF-A]), below the lithostratigraphic Unit I-II transition, suddenly drop at $\sim 99.5 \mathrm{mbsf}$ ( 101 m CCSF-A), which coincides with the lithologic change from diatom-bearing to diatom-rich silty clays (lithostratigraphic Subunit IIa-IIb transition), as well as a shift to slightly lower values at $\sim 248$ mbsf ( 264 m CCSF-A; lithostratigraphic Unit II/III boundary).

Downhole logging measurements in Hole U1359D were made after completion of RCB coring to a total depth of 602.2 mbsf (drilling depth below seafloor). Three tool strings were deployed in Hole U1359D, the triple combination (triple combo), Formation MicroScanner (FMS)-sonic, and Versatile Sonic Imager. Hole U1359D was divided into two logging units (100-260 and 260-606 mbsf) on the basis of the logs (Fig. F10 in the "Site U1359" chapter). The upper logging unit is characterized by high-amplitude swings in bulk density, NGR, and resistivity values. The transition to the unit below is gradual. Logging Unit 2 is characterized by generally lower amplitude bulk density and resistivity variations than the unit above, but the $2-5 \mathrm{~m}$ scale alternations are still clearly defined. NGR continues to show high variability, and several large drops in NGR values are observed between 350 and 450 mbsf. Near the base of the hole at 574-580 mbsf, a $6 \mathrm{~m}$ interval of higher bulk density and resistivity indicates a cemented bed or series of cemented beds. Heat flow at Site U1359 was estimated at $62.4 \mathrm{~mW} / \mathrm{m}^{2}$, a typical value for the ocean floor.

\section{Site U1360}

Site U1360 (proposed Site WLSHE-09B) is on the continental shelf off the Adélie Coast (Fig. F17) at 495 mbsl (Fig. F17; Table T1). The main objective at Site U1360 was to core across regional unconformity WL-U3 to determine the timing and nature of the first arrival of the ice sheet to the Wilkes Land Continental Margin. Site U1360 lies at the eastern edge of the Adélie Bank and receives drainage from the EAIS through the Wilkes subglacial basin. Glacier ice and the entrained debris draining through the basin and extending to the continental shelf would provide evidence for a large-scale ice sheet on Antarctica.

Regional unconformity WL-U3 was interpreted to record the first expansion of the EAIS across the shelf in this sector of the East Antarctic margin and therefore to separate preglacial strata below from glacial strata above (Eittreim et al., 1995; Escutia et al., 1997; De Santis et al., 2003). Drilling in Prydz Bay during Leg 188 (O'Brien, Cooper, Richter, et al., 2001) and results from Leg 28 Site 269 (Hayes, Frakes, et al., 1975), Leg 189 sites in the Tasman Gateway (Exon, Kennett, Malone, et al., 2001), and ODP Leg 182 Site 1128 in the Great Australian Bight (e.g., Mallinson et al., 2003), among others, led Escutia et al. (2005) to postulate an early Oligocene age (i.e., 33.5-30 Ma) for the development of unconformity WL-U3.

At Site U1360, unconformity WL-U3 was predicted to occur at $\sim 165 \mathrm{mbsf}(0.81 \mathrm{~s}$ TWT) (Fig. F21). Multichannel seismic reflection profiles crossing Site U1360 show gently dipping strata on the shelf truncated near the seafloor (Fig. F21). This provides a unique opportunity to sample across the unconformity with very shallow penetration. The proximal record from Site U1360 will complement the distal record of the first arrival of the EAIS to the Wilkes Land margin obtained at Site U1356.

Hole U1360A was drilled to a total depth of $70.8 \mathrm{mbsf}$ using the RCB system. Only $60 \mathrm{~cm}$ was recovered in the upper $14.3 \mathrm{mbsf}$, and sediments are unconsolidated and moderately to strongly disturbed by drilling (Core 318-U1360A-1R). Below 14.3 mbsf (Cores $2 \mathrm{R}$ through $6 \mathrm{R}$ ), the sediments are consolidated and most recovered intervals are only slightly disturbed by drilling. Based on visual core descriptions and smear slide analyses, cores from Hole U1360A are composed of diamictons, mudstones, sandstones, and diamictites that are placed into two lithostratigraphic units. Unit I (0-14.3 mbsf) consists of unconsolidated clast-rich sandy diamicton (Fig. F3 in the "Site U1360" chapter). The diamicton is slightly 
compacted but soft and crudely stratified and includes one lamination of yellowish clay-rich diatom ooze in interval 318-U1360A-1R-1, 18-20 cm. A trace of diatoms is present in the matrix of the diamictite. Rare shell fragments are also present in this unit. Clast percentages are as high as $25 \%$, and clasts are primarily composed of angular, indurated, olivegreen to olive-brown mudstone fragments, $2-8 \mathrm{~mm}$ in size. Crystalline rock clasts, including basalt and gneiss and as large as $7 \mathrm{~cm}$, have subrounded and faceted shapes. The unconsolidated diamictons were probably deposited from floating ice and most likely represent deposition from a floating glacier tongue or icebergs releasing debris over the site. The lamination of diatom ooze is indicative of a brief period of open-marine conditions with high productivity and low terrigenous sedimentation rates.

The top of Unit II (at $14.3 \mathrm{mbsf}$ ) marks a sharp change in lithology and induration of the cores, from unconsolidated diamicton above to carbonatecemented claystone below. An early Oligocene age is assigned to the interval below interval 318-U1360A$3 \mathrm{R}-1,8 \mathrm{~cm}$, whereas no age assignment is possible for Core 318-U1360A-2R (see "Biostratigraphy" in the "Site U1360" chapter). Five different lithofacies are recognized in a sequence from top to bottom in this unit:

1. Olive-green claystone with moderate bioturbation,

2. Dark green claystone with dispersed clasts,

3. Dark greenish gray sandy mudstone with dispersed clasts (Fig. F4 in the "Site U1360" chapter),

4. Olive-brown sandstone with dispersed clasts (Fig. F5 in the "Site U1360" chapter), and

5. Gray clast-rich sandy diamictite (Fig. F6 in the "Site U1360" chapter).

Overall, Unit II can be characterized as a finingupward sequence from diamictite at the base to claystone at the top. Bivalve shell fragments, some of which are pyritized, are common in the lower portion of Unit II. The lithofacies distribution is consistent with an ice-proximal to ice-distal glaciomarine depositional environment, similar to that described from the Oligocene and Miocene strata of the Victoria Land Basin, Ross Sea, Antarctica (Naish et al., 2001; Powell and Cooper, 2002). Five samples from Hole U1360A were prepared for X-ray diffraction analysis of the clay fraction. A mixture of all the major clay mineral groups characterizes the clay mineral assemblages in these samples. The dominant clay mineral components are smectite, illite, and chlorite, with a lesser contribution of kaolinite and pyrophyllite-talc (Fig. F7 in the "Site U1360" chapter). The cores assigned to the early Oligocene have clay mineral assemblages similar to those reported from lower Oligocene shelf strata around the Antarc- tic margin (e.g., Hambrey et al., 1991; Ehrmann et al., 2005). The abundance of illite and chlorite are consistent with a glacial-marine depositional setting for the claystone, mudstone, sandstone, and diamictite facies described within lithostratigraphic Unit II. The relatively large contribution of talc, however, is not typical of Paleogene sediments on the Antarctic shelf and may reflect the weathering of a low-grade metamorphic facies, derived from a basic or ultrabasic igneous protolith, locally on the Wilkes Land margin or within the Wilkes subglacial basin.

Dinocysts and diatoms provide age control for Hole U1360A. They suggest that Core 318-U1360A-1R (00.54 mbsf) comprises an uppermost Pleistocene matrix with intraclasts of upper Eocene to lower Oligocene material. An age could not be assigned to the strata between Section 318-U1360A-1R-CC and interval 318-U1360A-3R-1, $8 \mathrm{~cm}$ (0.54-23.38 mbsf), because of poor recovery. Samples 318-U1360A-3R-1, $8 \mathrm{~cm}$, to $6 \mathrm{R}-\mathrm{CC}(23.38-53.78 \mathrm{mbsf})$ are of early Oligocene $(<33.6 \mathrm{Ma})$ age.

Sediments within Core 318-U1360A-1R (0-0.54 mbsf) comprise an uppermost Pleistocene matrix with intraclasts of late Eocene to early Oligocene age. Diatoms indicate that during the latest Pleistocene, the shelf at Hole U1360A was not subjected to year-round ice cover but was influenced by seasonal sea ice either directly or indirectly. Combined microfossil analyses allow the interval below 318-U1360A-3R-1, $8 \mathrm{~cm}$ (23.38 mbsf), to be assigned to the early Oligocene $(<33.6 \mathrm{Ma})$ with confidence. Since these are derived from the same lithostratigraphic Unit II as strata between 14.3 and $23.38 \mathrm{mbsf}$, the entire Unit II is considered to be of early Oligocene. Early Oligocene microfossils indicate a shallow-water shelf environment with low salinities and high nutrient levels, likely driven by seasonal sea ice. Sporomorphs may represent reworking from older strata and/or contemporaneous vegetation in the hinterland.

Two samples from cores of Hole U1360A (Samples 318-U1360A-4R-1, $15 \mathrm{~cm}$, and 4R-2, $72 \mathrm{~cm}$ ) have reverse polarity, consistent with the age of Chron C12r as indicated by the biostratigraphy (see "Biostratigraphy" in the "Site U1360" chapter).

The fining-upward sequence from diamictites at the base (Core 318-U1360A-6R) to claystones at the top (Cores 2R through 3R) (see "Lithostratigraphy" in the "Site U1360" chapter) is also documented in the general decrease in magnetic susceptibility values from the bottom to the top of the hole. Variations in GRA density nicely reflect variations in lithology between clast-rich diamictite, sandy mudstone with dispersed clasts, and claystone. Calculated porosity ranges from $49 \%$ to $17 \%$ and generally decreases with depth. Grain densities range from 2.62 to $2.7 \mathrm{~g} / \mathrm{cm}^{3}$. 


\section{Site U1361}

Site U1361 (proposed Site WLRIS-05A) is located on the continental rise at $3454 \mathrm{mbsl}$ (Fig. F22; Table T1). Similar to Site U1359, the main objective at Site U1361 was to provide a history of climate and paleoceanographic variability record from the middle Miocene to the Pleistocene and to test the stability of the EAIS during extreme warm periods (e.g., Miocene climate optimum, early Pliocene, and Pleistocene marine isotope Stages 31 and 11). Drilling at this site targeted the timing and nature of deposition of the upper seismic units (i.e., above unconformity WLU6) defined on the Wilkes Land margin (De Santis et al., 2003; Donda et al., 2003) (Fig. F23). Within these units, a shift in sedimentary depocenters from the continental rise to the outer shelf possibly corresponds to the transition from a dynamic wet-based EAIS to a more persistent cold-based EAIS (Escutia et al., 2002; De Santis et al., 2003), which is inferred to occur during the late Miocene-Pliocene (Escutia et al., 2005; Rebesco et al., 2006). At Site U1361, unconformities WL-U6, WL-U7, and WL-U8 lie at approximately $5.13,5.03$, and $4.78 \mathrm{~s}$ TWT, respectively (approximately 385, 300, and $100 \mathrm{mbsf}$, respectively) (Fig. F23).

Site U1361 is located on the right (east) levee of the Jussieau submarine channel downstream from Site U1359 (Figs. F22, F23). The levee relief (measured from the channel thalweg to the top of the levee) at Site U1361 is $\sim 195 \mathrm{~m}$ (Fig. F23). The fine-grained components of the turbidity flows traveling through the channel and hemipelagic drape are inferred to be the dominant sedimentary processes building these levees (Escutia et al., 1997, 2000; Donda et al., 2003). Bottom currents can further influence sedimentation in this setting (Escutia et al., 2002; Donda et al., 2003). The record from Site U1361 should be complementary to the record from Site U1359. Similar depositional environments were cored during Leg 178 along the Antarctic Peninsula (Barker, Camerlenghi, Acton, et al., 1999) and Leg 188 in Prydz Bay (O'Brien, Cooper, Richter, et al., 2001).

Two holes were drilled at Site U1361. Hole U1361A reached a total depth of $388.0 \mathrm{mbsf}$. The APC system was used to refusal at $151.5 \mathrm{mbsf}$, followed by XCB drilling to the bottom of the hole at $388.0 \mathrm{mbsf}$. Hole U1361B reached 12.1 mbsf using the APC system. Five lithofacies (designated A-E) were identified at Site U1361, and based on their distribution in Hole U1361A, two lithostratigraphic units are defined (Fig. F3 in the "Site U1361" chapter). Facies A and B consist of clays and silty clays with common diatoms and foraminifer and rare decimeter-scale sets of millimeter- to centimeter-scale silt and clay laminations. These facies are restricted to the inter- val between 0.0 and 34.9 mbsf (lithostratigraphic Unit I). Facies A and B were deposited in hemipelagic depositional environments, with isolated sets of silt and clay laminations indicating occasional sedimentation from low-density turbidity currents or saline density flows in a distal levee setting (Escutia et al., 2008). Facies $C$ and D are strongly bioturbated silty clays and diatom/nannofossil oozes with intervals containing dispersed clasts. Facies E consists of laminated clays. Facies C-E are present between 34.9 and 386.3 mbsf (lithostratigraphic Unit II) and are typical of contourite facies associations, although downslope currents possibly contributed sediment as well. Samples 318-U1361A-1H-CC through 41X-CC (1.5386.31 mbsf) were analyzed for microfossils. Diatoms and radiolarians provide good age control for Hole U1361A, resolving an uppermost middle Miocene through uppermost Pleistocene sedimentary succession with no major breaks in sedimentation (Fig. F4 in the "Site U1361" chapter).

Miocene diatom assemblages at Site U1361 are indicative of productive, seasonally variable open-marine conditions. Fluctuations in the abundance of marine benthic and tychopelagic taxa such as Cocconeis spp., Diploneis spp., Paralia sulcata, stephanopyxids, and Trinacria excavata may indicate pulses of shelfal material to the drill site. The presence of well-preserved benthic foraminifers in Sample 318-U1361A-34X-CC (321.07 mbsf) suggests that depositional settings were favorable for calcite preservation (i.e., not corrosive) for brief intervals in the Miocene. The persistent presence of reworked Mesozoic-Paleozoic sporomorphs within the palynological associations suggests ongoing erosion in the hinterland.

Late Neogene diatom assemblages from sediments drilled at Site U1361 are typical Southern Ocean open-water taxa with variable abundances of benthic, neritic, and sea ice-associated diatoms, indicating a high-nutrient, high-productivity sea ice-influenced setting throughout the late Neogene. High abundances of reworked sporomorphs within the palynological associations indicate strong erosion in the hinterland. Dinocysts are absent in this interval. The preservation of planktonic foraminifers in the Pleistocene indicates that bottom waters were favorable to the preservation of calcium carbonate.

Paleomagnetic investigations at Site U1361 document a complete section from the top of Chron C2n to the top of Chron C3n. Below Chron C2n, the recovered core was disturbed, and no complete analysis of the discrete samples is obtainable as of yet. The lower portion of Hole U1361A can plausibly be correlated to the bottom of Chron C5n to Chron C5An.

Forty samples from Hole U1361A were taken for analyses of carbonate, carbon, nitrogen, and sulfur 
content, as well as major and trace elements. As a result of technical problems with the inductively coupled plasma-atomic emission spectrometer, no major and trace element analyses could be obtained. $\mathrm{CaCO}_{3}$ contents for most samples are well below detection limit $(<1 \quad w t \%)$. Between 313.96 and 342.04 mbsf, however, carbonate contents increase to $12.1-24.8 \mathrm{wt} \%$. This matches the recognition of nannofossil-bearing clays constituting one of three major facies below 313.2 mbsf (lithostratigraphic Subunit IIb; see "Lithostratigraphy" in the "Site U1361" chapter). Carbon, nitrogen, and sulfur contents were measured on 15 selected samples covering the full range of $\mathrm{CaCO}_{3}$ contents (0-24.8 wt\%). All concentration levels are very low (i.e., $\mathrm{C}<0.5 \mathrm{wt} \%$, $\mathrm{N}<0.03 \mathrm{wt} \%$, and $\mathrm{S}<0.02 \mathrm{wt} \%$ ) except for the four samples with high calcium carbonate contents. Taken together with the $\mathrm{CaCO}_{3}$ measurements, these samples yield total organic carbon concentrations $<0.3 \mathrm{wt} \%$, which is within the error for the respective measurements.

The physical property program at Site U1361 included routine runs on the WRMSL, which includes the GRA) density, magnetic susceptibility, and PWL sensors, as well as NGR measurements. $P$-wave velocity measurements were also taken, and samples were taken and analyzed for moisture, density, and porosity. Thermal conductivity measurements were made in one section of all cores. The magnetic susceptibility data exhibit relatively high amplitude variations, and this apparent cyclicity at several scales occurs especially in the upper $165 \mathrm{mbsf}$ and between $305 \mathrm{mbsf}$ and the bottom of the hole. There are two intervals with recurring, relatively lower magnetic susceptibility units between 165 and 185 mbsf and between 265 and 305 mbsf. The variations in GRA density reflect the regular fluctuations in lithology and porosity. The relative moisture content varies between 63 and $22 \mathrm{wt} \%$, and porosity varies from $82 \%$ to $42 \%$ with a gradual decrease with increasing depth and overburden pressure. A common feature of density, porosity, and water content records of Site U1361 is a slight change to higher gradients below 330 mbsf that occurs within lithostratigraphic Subunit IIb.

Downhole logging operations started after a successful reentry of Hole U1361A, which had been left temporarily to allow an iceberg to pass. Both the triple combo and FMS-sonic tool strings logged from $\sim 100$ mbsf to the base of Hole U1361A. The downhole logs in Hole U1361A have high-amplitude 1$5 \mathrm{~m}$ scale variability superimposed on a downhole compaction trend. The character of the logs changes gradually downhole, with no major steps in the base levels, so the entire logged interval was assigned to one logging unit. It is likely that Milankovitch band variability at eccentricity and possibly obliquity periods is recorded at Site U1361. The downhole measurements at Site U1361 included four advanced piston corer temperature tool (APCT-3) deployments in Hole U1361A. Thermal resistance was calculated over the intervals overlying the APCT-3 measurements, and the resulting linear fit of the temperature gives a heat flow value of $58.2 \mathrm{~mW} / \mathrm{m}^{2}$.

\section{Preliminary scientific assessment}

The overall objective of Expedition 318 was to obtain long-term record of Antarctic glaciation and its relationships with global paleoclimate and paleoceanographic and eustatic sea level changes by drilling the Antarctic margin along an inshoreoffshore transect. Of particular interest was testing the sensitivity of the EAIS to episodes of global warming and detailed analysis of critical periods in Earth's climate history (i.e., the Eocene-Oligocene and Oligocene-Miocene glaciations, late Miocene, Pliocene, and the last deglaciation) during which the Antarctic cryosphere evolved in a step-wise fashion to ultimately assume its present-day configuration, characterized by a relatively stable EAIS. These records were obtained by coring and analyzing sedimentary records along the inshore-offshore transect to constrain the age, nature, and environments of deposition, until now only inferred from seismic surveys of the Wilkes Land continental shelf, rise, and abyssal plain.

The principal goals were

1. To obtain the timing, nature, and consequences of the first major phase of EAIS growth and arrival of ice at the Wilkes Land margin (onset of glaciation) inferred to have occurred during the earliest Oligocene. In marine records elsewhere, this event is thought to correlate to a steep increase in oceanic $\delta^{18} \mathrm{O}$ values widely referred to as Oi-1 (Miller et al., 1985);

2. To obtain the nature and ages of the changes in the geometries of the progradational wedges interpreted to correspond with large fluctuations in the extent of the EAIS and possibly coinciding with the transition from a wet-based to a coldbased glacial regime;

3. To obtain a high-resolution record of Antarctic climate variability during the Oligocene, Neogene, and Quaternary; and

4. To obtain an unprecedented ultrahigh resolution (i.e., seasonal to decadal) Holocene record of climate variability.

Expedition 318, January-March 2010 (Wellington to Hobart), occupied seven sites (Fig. F6) that produced 
$\sim 2000 \mathrm{~m}$ of high-quality upper Eocene-Quaternary sediments (Fig. F24). Sites U1355, U1356, U1359, and U1361 are on the Wilkes Land rise and Sites U1358, U1360, and U1357 are on the Wilkes Land shelf at water depths between $\sim 400$ and 4000 mbsl. Together, the cores represent $\sim 53 \mathrm{~m}$.y. of Antarctic history (Figs. F24, F25). The cores reveal the history of the Wilkes Land Antarctic margin from an ice-free "greenhouse Antarctica," to the first cooling, to the onset and erosional consequences of the first glaciation and the subsequent dynamics of the waxing and waning ice sheets, all the way to thick, unprecedented "tree ring style" records with seasonal resolution of the last deglaciation that began $\sim 10,000 \mathrm{y}$ ago (Fig. F26). They also reveal details of the tectonic history of the so called Australo-Antarctic Gulf (at $53 \mathrm{Ma}$ ), the onset of the second phase of rifting between Australia and Antarctica (Colwell et al., 2006; Close et al., 2009), ever-subsiding margins and deepening, all the way to the present ocean/continent configuration. Tectonic and climatic change turned the initially shallow, broad subtropical Antarctic Wilkes Land offshore shelf into a deeply subsided basin with a narrow ice-infested margin (Fig. F26). Thick Oligocene and notably Neogene deposits, including turbidites, contourites, and larger and smaller scaled debris mass flows, witness the erosional power of the waxing and waning ice sheets and deep-ocean currents. The recovered clays, silts, and sands and their microfossils also reveal the transition of subtropical ecosystems and a vegetated Antarctica into sea ice-dominated ecosystems bordered by calving glaciers (Fig. F26).

\section{"Preglacial" regional unconformity WL-U3 and the timing, nature, and consequences of the first major phase of EAIS growth}

Strata above and below unconformity WL-U3, interpreted precruise to separate preglacial strata from glacial-influenced deposits, was drilled and dated at continental rise Site U1356 (Figs. F24, F25, F27). We confirmed that this surface represents major erosion related to the onset of glaciation at $\sim 34$ Ma (early Oligocene), with immediately overlying deposits dated as 33.3 Ma. We sampled strata overlying the unconformity at the inshore shelf Site U1360 and dated it as early Oligocene ( 33.6 Ma) (Fig. F25). Below unconformity WL-U3, we recovered a late early to early middle Eocene record from peak greenhouse conditions, likely including some of the early Eocene hyperthermals, at Site U1356 (Figs. F25, F27). Subtropical shallow-water depositional environments are indicated by dinocysts and the chemical index of alteration, among other indicators (i.e., clay mineralogy; see "Site U1356") (Fig. F27). A hiatus spanning
2 m.y. separates the lower Eocene from the middle Eocene record at Site U1356 according to dinocyst and magnetostratigraphic evidence. This hiatus may be related to tectonic activity related to the commencement of rapid seafloor spreading in the $\mathrm{AAB}$, reported to initiate around the same time ( $\sim 50 \mathrm{Ma})$ (Colwell et al., 2006; Close et al., 2009). Combined Site U1356 and Leg 189 dinocyst distribution patterns suggest earliest through-flow of South Pacific Antarctic waters through the Tasmanian Gateway to also be coeval with this tectonic phase (Fig. F28). Sedimentological and microfossil information from this interval from Hole U1356A also suggest progressive deepening during the early middle Eocene.

The upper middle Eocene to the basal Oligocene is conspicuously missing in a $\sim 19$ m.y. hiatus at $\sim 890$ mbsf ( 47.9-33.6 Ma) based on dinocyst and paleomagnetic evidence in sediments below regional unconformity WL-U3 (Figs. F25, F27). Despite ongoing tectonic reorganizations, it appears likely that the erosive nature of unconformity WL-U3 is notably related to the early stages of EAIS formation. The combination of concomitant internal dynamics, sea level response, ice sheet growth, and potentially related erosion is proposed as the principal mechanism underlying the formation of regional unconformity WL-U3. This is supported by the abrupt steep increase in oceanic $\delta^{18} \mathrm{O}$ values (Oi-1) and coeval sea level change globally recorded in marine successions (Oi-1; Miller et al., 1985). Nevertheless, progressive subsidence, the large accommodation space created by erosion in the margin (300-600 $\mathrm{m}$ of missing strata) (Eittreim et al., 1995), and partial eustatic recovery allowed sediments of early Oligocene age to accumulate above unconformity WL-U3.

Microfossil contents, sedimentology, and geochemistry of the Oligocene sediments from Site U1356, at present occupying a distal setting (i.e., lowermost riseabyssal plain) and immediately above unconformity WL-U3, unequivocally reflect icehouse environments with evidence of iceberg activity (dropstones) and at least seasonal sea ice cover (Figs. F26, F27). The sediments, dominated by hemipelagic sedimentation with bottom current and gravity flow influence, as well as biota, indicate deeper water settings relative to the underlying middle Eocene environments. These findings imply significant crustal stretching, subsidence of the margin, and deepening of the Tasman Rise and the Adélie Rift Block between 47.9 and 33.6 Ma (Figs. F26, F28). Furthermore, combined paleoenvironmental data indicate significantly cooler, high-productivity, and sea ice-influenced surface waters, with only occasional incursions of warmer conditions. We surmise that as AntarcticAustralian separation progressed and deepening took 
place, influence from the warmer waters of the Proto-Leeuwin Current gradually diminished, whereas Antarctic Counter Current flow and deepwater formation along the Wilkes Land margin strengthened (Fig. F28).

\section{Record of EAIS variability and the nature and ages of the changes in the geometries of progradational wedges}

Drilling at continental rise Site U1356 also recovered a thick section of Oligocene to upper Miocene sediments (Figs. F24, F25) indicative of a relatively deep water, sea ice-influenced setting (Fig. F26). Oligocene to upper Miocene (Figs. F24, F25) sediments are indicative of episodically reduced oxygen conditions either at the seafloor or within the upper sediments prior to $\sim 17 \mathrm{Ma}$. From the late early Miocene $(\sim 17 \mathrm{Ma})$ onward, progressive deepening and possible intensification of deep water flow and circulation lead to a transition from a poorly oxygenated lowsilica system (present from the early to early middle Eocene to late early Miocene) to a well-ventilated silica-enriched system akin to the modern Southern Ocean. This change coincides with one of the major regional unconformities in the Wilkes Land margin, unconformity WL-U5, which represents a $\sim 3$ m.y. latest Oligocene-early Miocene hiatus (Figs. F24, F25, F27). This unconformity marks a change in the dominant sedimentary processes at this site, which are dominated by mass transport processes below the unconformity and by hemipelagic, turbidity flow, and bottom-current deposition above. Further studies are needed to determine to what extent the observed changes are related to relevant steps in the evolution of the EAIS, changes in the continental shelf morphology (i.e., shelf overdeepening), or both.

A complete record with good recovery of late Miocene to Pleistocene deposits was achieved at continental rise Sites U1359 and U1361 (Figs. F24, F25), drilled on levee deposits bounding turbidity channels. We successfully dated the seismic units between unconformities WL-U6 and WL-U8, and the sedimentological, logging, and magnetic susceptibility data exhibit relatively high amplitude variations, indicating strong potential for shore-based analysis revealing EAIS dynamics down to orbital timescales (100 and 40 k.y. cyclicity). This cyclicity likely documents the successive advances and retreats of the ice sheet and sea ice cover, as well as the varying intensity of cold saline density flows related to bottom water production at the Wilkes Land margin (e.g., high-salinity shelf water flowing from the shelf into the deep ocean to form AABW). In general, typical Southern Ocean open cold-water taxa, with variable abundances of sea ice-associated diatoms, indicate a high-nutrient, high-productivity sea ice-influenced setting throughout the Neogene. Combined sedimentological and microfossil information indicates the ever-increasing influence of typical Antarctic Counter Current surface waters and intensifying AABW flow (Figs. F26, F28). Furthermore, the preservation of calcareous microfossils in several intervals indicates times when bottom waters were favorable to the preservation of calcium carbonate. These observations point to a very dynamic ice sheet/sea ice regime during the late Miocene through the Pleistocene. Detailed postcruise studies in sediments from the late Neogene will provide a history of glacialinterglacial climate and paleoceanographic variability, including a history of AABW production, that can be linked to sea ice variations in this margin.

Continental shelf Site U1358 (Figs. F24, F25) recovered a record from the early Pliocene to Pleistocene (with a small hiatus at $\sim 2.5 \mathrm{Ma}$ ). Although targeted unconformity WL-U8 was not reached, glacial and glacial-marine sediments recovered at this site are dated early early Pliocene. Therefore, the change in the geometries of the progradational wedge from low-angle progradational strata above to very steep foresets is older than $4.5 \mathrm{Ma}$. In addition, the record from Site U1358 in combination with those from Sites U1359 and U1361 will provide the link between ice sheet behavior on the continental shelf, including times of ice sheet instability (e.g., early Pliocene warmth) and the history of sea ice and paleoceanographic changes recorded at Sites U1359 and U1361.

\section{Ultrahigh resolution (seasonal to decadal) Holocene record of climate variability}

Coring at Site U1357 yielded a 186 m section of continuously laminated diatom ooze as well as a portion of the underlying Last Glacial Maximum diamict. Based on much shorter piston cores recovered from adjacent basins and banks, the onset of marine sedimentation during the deglacial interval began between 10,400 and 11,000 y ago. The site was triple cored, providing overlapping sequences that will aid in the construction of a composite stratigraphy spanning at least the last 10,000 y. The Site U1357 sediments are unusual for Antarctic shelf deposits because of their high accumulation rate $(2 \mathrm{~cm} / \mathrm{y})$, lack of bioturbation, and excellent preservation of organic matter as well as calcareous, opaline, phosphatic, and organic fossils. The sediments are profoundly anoxic, with levels of $\mathrm{H}_{2} \mathrm{~S}$ as high as $42,000 \mathrm{ppm}$ at 20 mbsf. Larger burrowing organisms are completely excluded from this ecosystem, yet the regular occurrence of benthic foraminifers suggests that some oxygen is present at the sediment/water interface. The mineral struvite, a hydrous ammonium 
phosphate phase, forms in nitrogen-rich pore waters and has never before been reported in Antarctic sediment. These sediments provide an excellent sample set for geomicrobiology and sedimentary geochemistry studies. In fact, the upper $20 \mathrm{~m}$ of one of the three holes was completely consumed for pore water and sediment studies.

The greatest achievement from a paleoclimatic standpoint was the retrieval of a continuously layered deposit (Fig. F29). Spot checks of laminae from top to bottom of the split Hole U1357A sections suggests that paired light-dark laminae sets range in thickness from $\sim 1$ to $3 \mathrm{~cm}$. Based on radiocarbon dating of a piston core taken earlier from this site (Costa et al., 2007), our own preliminary secular paleomagnetic findings, and the thickness of the deposit combined with the expected age at its base, it is very likely each laminae pair represents $1 \mathrm{y}$. If supported by our shore-based research, this will be the first varved sedimentary sequence extending through the Holocene recovered from the Southern Ocean. Analysis at the annual timescale will permit us to examine decadal to subdecadal variability in sea ice, temperature, and wind linked to the SAM, Pacific Decadal Variability, and possibly ENSO. We will also be able to address questions regarding rates of change during the Hypsithermal Holocene neoglacial events and the time immediately following the first lift-off and pull-back of ice at the end of the last glacial interval. In addition, we now have an excellent opportunity for ultrahigh resolution correlation to the nearby Law Dome Ice Core, one of the most important Holocene ice cores in Antarctica.

Microscopic analyses of smear slides, micropaleontological slides, and palynological preparations reveal the presence of an unusually well preserved and diverse assemblage of both soft and hard biotic remains, including abundant fish, copepods, and euphausiids. In fact, these sediments may well have captured the most complete record of any ancient ecosystem structure and its variability through the Holocene yet recovered from the Southern Ocean.

\section{References}

Anderson, J.B., 1999. Antarctic Marine Geology: Cambridge (Cambridge Univ. Press).

Anderson, J.B., Kurtz, D.D., Domack, E.W., and Balshaw, K.M., 1980. Glacial and glacial marine sediments of the Antarctic continental shelf. J. Geol., 88(4):399-414. doi:10.1086/628524

Armand, L.K., Crosta, X., Romero, O., and Pichon, J.-J., 2005. The biogeography of major diatom taxa in Southern Ocean sediments: 1 . Sea ice related species. Palaeogeogr., Palaeoclimatol., Palaeoecol., 223(1-2):93-126. doi:10.1016/j.palaeo.2005.02.015
Baker, P.A., Seltzer, G.O., Fritz, S.C., Dunbar, R.B., Grove, M.J., Tapia, P.M., Cross, S.L., Rowe, H.D., and Broda, J.P., 2001. The history of South American tropical climate for the past 25,000 years. Science, 291(5504):640-643. doi:10.1126/science.291.5504.640

Barker, P.F., Camerlenghi, A., Acton, G.D., et al., 1999. Proc. ODP, Init. Repts., 178: College Station, TX (Ocean Drilling Program). doi:10.2973/odp.proc.ir.178.1999

Barker, P.F., and Thomas, E., 2004. Origin, signature and palaeoclimatic influence of the Antarctic Circumpolar Current. Earth-Sci. Rev., 66(1-2):143-162. doi:10.1016/ j.earscirev.2003.10.003

Barnes, P.W., 1987. Morphologic studies of the Wilkes Land continental shelf, Antarctica-glacial and iceberg effects. In Eittreim, S.L., and Hampton, M.A. (Eds.), The Antarctic Continental Margin: Geology and Geophysics of Offshore Wilkes Land: Circum-Pacific Council for Energy and Mineral Resources (Houston, TX), CPCEMR Earth Sci. Ser., 5A:175-194.

Barrett, P.J., 2009. Cenozoic climate and sea level history from glacimarine strata off the Victoria Land coast, Cape Roberts Project, Antarctica. In Hambrey, M.J., Christoffersen, P., Glasser, N.F., and Hubbard, B. (Eds.), Glacial Sedimentary Processes and Products: Spec. Publ. Int. Assoc. Sedimentol., 39.

Brancolini, G., Harris, P., Armand, L., Brown, B., Busetti, M., Childs, J.R., Deen, T., Giorgetti, G., Hislop, A., Hill, A., King, A., Miller, K., Pelos, C., Presti, M., Robertson, L., Rosenberg, M., Sormani, L., Sullivan, P., Trincardi, F., Vidmar, R., Weber, P., Wilcox, S., and Woon, S., 2000. Post cruise report AGSO Survey 217: joint Italian/Australian marine geoscience expedition aboard the R.V. Tangaroa to the George Vth Land region of East Antarctica during February-March 2000. Rec. Austral. Geol. Surv. Org., 2000.

Brinkhuis, H., Munsterman, D.K., Sengers, S., Sluijs, A., Warnaar, J., and Williams, G.L., 2003a. Late EoceneQuaternary dinoflagellate cysts from ODP Site 1168, off western Tasmania. In Exon, N.F., Kennett, J.P., and Malone, M.J., Proc. ODP, Sci. Results, 189: College Station, TX (Ocean Drilling Program), 1-36. doi:10.2973/ odp.proc.sr.189.105.2003

Brinkhuis, H., Sengers, S., Sluijs, A., Warnaar, J., and Williams, G.L., 2003b. Latest Cretaceous-earliest Oligocene and Quaternary dinoflagellate cysts, ODP Site 1172, East Tasman Plateau. In Exon, N.F., Kennett, J.P., and Malone, M.J., Proc. ODP, Sci. Res., 189: College Station, TX (Ocean Drilling Program), 1-36. doi:10.2973/ odp.proc.sr.189.106.2003

Cande, S.C., and Mutter, J.C., 1982. A revised identification of the oldest sea-floor spreading anomalies between Australia and Antarctica. Earth Planet. Sci. Lett., 58(2):151-160. doi:10.1016/0012-821X(82)90190-X

Close, D.I., Watts, A.B., and Stagg, H.M.J., 2009. A marine geophysical study of the Wilkes Land rifted continental margin, Antarctica. Geophys. J. Int., 177(2):430-450. doi:10.1111/j.1365-246X.2008.04066.X

Colwell, J.B., Stagg, H.M.J., and Direen, N.G., 2006. Geology of deep-water margin of East Antarctica between Queen Mary and George V Lands. In Futterer, D.K. (Ed.), 
Terra Nostra: Proceedings of the Ninth International Symposium of Antarctic Earth Science.

Colwell, J.B., Stagg, H.M.J., Direen, N.G., Bernander, G., Borisova, I., 2006b. The structure of the continental margin off Wilkes Land and Terre Adelie Coast, East Antarctica. In: Futterer, Damaslie, Kleinschmidt, Miller, Tessensohn (eds) Antarctica contributions to global earth sciences. Springer-Verlag. Berlin Heidelberg New York pp 327-340.

Cooper, A.K., Brancolini, G., Escutia, C., Kristoffersen, Y., Larter, R., Leitchenkov, G., O'Brien P., and Jokat, W., 2009. Cenozoic climate history from seismic reflection and drilling studies on the Antarctic continental margin. In Florindo, F., and Siegert, M. (Eds.), Developments in Earth and Environmental Sciences (Vol. 8): Antarctic Climate Evolution: Amsterdam (Elsevier), 115-228.

Cooper, A.K., O’Brien, P.E., and Richter, C. (Eds.), 2004. Proc. ODP, Sci. Results, 188: College Station, TX (Ocean Drilling Program). doi:10.2973/odp.proc.sr.188.2004

Costa, E., Dunbar, R.B., Kryc, K.A., Mucciarone, D.A., Brachfeld, S., Roark, E.B., Manley, P.L., Murray, R.W., and Leventer, A., 2007. Solar forcing and El NiñoSouthern Oscillation (ENSO) influences on productivity cycles interpreted from a late Holocene high-resolution marine sediment record, Adélie Drift, East Antarctic margin. In Cooper, A.K., and Raymond, C.R., et al. (Eds.), Antarctica: A Keystone in a Changing World. USGS Open-File Rep., 2007-1047:1-6. doi:10.3133/of20071047.srp036

Coxall, H.K., Wilson, P.A., Pälike, H., Lear, C.H., and Backman, J., 2005. Rapid stepwise onset of Antarctic glaciation and deeper calcite compensation in the Pacific Ocean. Nature (London, U. K.), 433(7021):53-57. doi:10.1038/nature03135

Crosta, X., Crespin, J., Billy, I., and Ther, O., 2005. Major factors controlling Holocene $\delta^{13} \mathrm{C}_{\text {org }}$ changes in a seasonal sea-ice environment, Adélie Land, East Antarctica. Global Biogeochem. Cycles, 19(4):GB4029. doi:10.1029/ 2004GB002426

Cunningham, W.L., Leventer, A., Andrews, J.T., Jennings, A.E., and Licht, K.J., 1999. Late Pleistocene-Holocene marine conditions in the Ross Sea, Antarctica: evidence from the diatom record. Holocene, 9(2):129-139. doi:10.1191/095968399675624796

DeConto, R.M., and Pollard, D., 2003a. A coupled climateice sheet modeling approach to the early Cenozoic history of the Antarctic ice sheet. Palaeogeogr., Palaeoclimatol., Palaeoecol., 198(1-2):39-52. doi:10.1016/S00310182(03)00393-6

DeConto, R.M., and Pollard, D., 2003b. Rapid Cenozoic glaciation of Antarctica induced by declining atmospheric $\mathrm{CO}_{2}$. Nature (London, U. K.), 421(6920):245-249. doi:10.1038/nature01290

DeConto, R., Pollard, D., and Harwood, D., 2007. Sea ice feedback and Cenozoic evolution of Antarctic climate and ice sheets. Palaeoceanography, 22(3):PA3214. doi:10.1029/2006PA001350

Denis, D., Crosta, X., Zaragosi, S., Romero, O., Martin, B., and Mas, V., 2006. Seasonal and subseasonal climate changes in laminated diatom ooze sediments, Adélie
Land, East Antarctica. Holocene, 16(8):1137-1147. doi:10.1177/0959683606069414

De Santis, L., Brancolini, G., and Donda, F., 2003. Seismostratigraphic analysis of the Wilkes Land Continental Margin (East Antarctica): influence of glacially driven processes on the Cenozoic deposition. Deep-Sea Res., Part II, 50(8-9):1563-1594. doi:10.1016/S09670645(03)00079-1

De Santis, L., Brancolini, G., Donda, F., and O'Brien, P., 2010. Cenozoic deformation in the George V Land continental margin (East Antarctica). Mar. Geol., 269(12):1-17. doi:10.1016/j.margeo.2009.12.001

De Santis, Domack, E., Duran, D., Leventer, A., Ishman, S., Doane, S., McCallum, S., Amblas, D., Ring, J., Gilbert, R., and Prentice, M., 2005. Stability of the Larsen B ice shelf on the Antarctic Peninsula during the Holocene epoch. Nature (London, U. K.), 436(7051):681-685. doi:10.1038/nature03908

Domack, E., Leventer, A., Dunbar, R., Taylor, F., Brachfeld, S., and Sjunneskog, C., 2001. Chronology of the Palmer Deep Site, Antarctic Peninsula: a Holocene paleoenvironmental reference for the circum-Antarctic. Holocene, 11(1):1-9. doi:10.1191/095968301673881493

Domack, E.W., 1982. Sedimentology of glacial and glacial marine deposits on the George V-Adelie continental shelf, East Antarctica. Boreas, 11(1):79-97.

Domack, E.W., Fairchild, W.W., and Anderson, J.B., 1980. Lower Cretaceous sediment from the East Antarctic continental shelf. Nature (London, U. K.), 287(5783):625626. doi:10.1038/287625a0

Domack, E.W., Jacobson, E.A., Shipp, S., and Anderson, J.B., 1999. Late Pleistocene-Holocene retreat of the West Antarctic ice-sheet system on the Ross Sea, Part 2. Sedimentological and stratigraphic signature. Geol. Soc. Am. Bull., 111(10):1517-1536. doi:10.1130/ 0016-7606(1999)111<1517:LPHROT>2.3.CO;2

Domack, E.W., Leventer, A., Root, S., Ring, J., Williams, E., Carlson, D., Hirshorn, E., Wright, W., Gilbert, R., and Burr, G., 2003. Marine sedimentary record of natural environmental variability and recent warming in the Antarctic Peninsula. In Domack, E., Leventer, A., Adam, B., Bindschadler, R., Convey, P., and Kirby, M. (Eds.), Antarctic Peninsula Climate Variability: Historical and Paleoenvironmental Perspectives. Antarct. Res. Ser., 79:205-224.

Domack, E.W., Mashiotta, T.A., Burkley, L.A., and Ishman, S.E., 1993. 300-year cyclicity in organic matter preservation in Antarctic fjord sediments. In Kennett, J.P., and Warnke, D.A. (Eds.), The Antarctic Paleoenvironment: A Perspective on Global Change, Pt. 2. Antarct. Res. Ser., 60:265-272.

Domack, E.W., and Mayewski, P.A., 1999. Bi-polar ocean linkages: evidence from late-Holocene Antarctic marine and Greenland ice-core records. Holocene, 9(2):247-251. doi:10.1191/095968399675385468

Donda, F., Brancolini, G., De Santis, L., and Trincardi, F., 2003. Seismic facies and sedimentary processes on the continental rise off Wilkes Land (East Antarctica): evidence of bottom current activity. Deep-Sea Res., Part II, 
50(8-9):1509-1527. doi:10.1016/S09670645(03)00075-4

Drewry, D.J., 1983. The record of late Cenozoic glacial events in East Antarctica $\left(60^{\circ}-171^{\circ} \mathrm{E}\right)$. In Hambrey, M.J., and Harland, W.B. (Eds.), Earth's Pre-Pleistocene Glacial Record: Cambridge (Cambridge Univ. Press), 212-216.

Drewry, D.J., and Cooper, A.P.R., 1981. Processes and models of Antarctic glaciomarine sedimentation. Ann. Glaciol., 2:117-122.

Dunbar, R.B., Anderson, J.B., Domack, E.W., and Jacobs, S.S., 1985. Oceanographic influences on sedimentation along the Antarctic continental shelf. In Jacobs, S.S. (Ed.), Oceanology of the Antarctic Continental Shelf. Antarctic Res. Ser., 43:291-312.

Eittreim, S.L., 1994. Transition from continental to oceanic crust on the Wilkes-Adelie margin of Antarctica. J. Geophys. Res., 99(B12):24189-24205. doi:10.1029/ 94JB01903

Eittreim, S.L., Cooper, A.K., and Wannesson, J., 1995. Seismic stratigraphic evidence of ice-sheet advances on the Wilkes Land margin of Antarctica. Sediment. Geol., 96(12):131-156. doi:10.1016/0037-0738(94)00130-M

Eittreim, S.L., and Hampton, M.A. (Eds.), 1987. The Antarctic continental margin: geology and geophysics of offshore Wilkes Land. Earth Sci. Ser. (N. Y.), 5A.

Eittreim, S.L., and Smith, G.L., 1987. Seismic sequences and their distribution on the Wilkes Land margin. In Eittreim, S.L., and Hampton, M.A. (Eds.), The Antarctic Continental Margin: Geology and Geophysics of Offshore Wilkes Land. Earth Sci. Ser. (N. Y.), 5A:15-43.

Ehrmann, W., Setti, M., and Marinoni, L., 2005. Clay minerals in Cenozoic sediments off Cape Roberts (McMurdo Sound, Antarctica) reveal palaeoclimatic history. Palaeogeogr., Palaeoclimatol., Palaeoecol., 229(3):187-211. doi:10.1016/j.palaeo.2005.06.022

Escutia, C., Bárcena, M.A., Lucchi, R., Romero, O., and Ballegeer, A.M., 2007. Early Pliocene circum-Antarctic warming events between 3.5 and 3.7 Ma recorded in sediments from ODP Sites 1165 (Prydz Bay) and 1095 and 1096 (Antarctic Peninsula). In Cooper, A., and Raymond, C., and the 10th ISAES Editorial Team (Eds.), Antarctica: A Keystone in a Changing World: Online Proceedings for the Tenth International Symposium on Antarctic Earth Sciences. USGS Open-File Rep., 2007-1047:104. (Abstract)

Escutia, C., Brinkhuis, H., and Klaus, A., 2008. Cenozoic East Antarctic ice sheet evolution from Wilkes Land margin sediments. IODP Sci. Prosp., 318. doi:10.2204/ iodp.sp.318.2008

Escutia C., De Santis, L., Donda, F., Dunbar, R.B., Cooper, A.K., Brancolini, G., and Eittreim, S.L., 2005. Cenozoic ice sheet history from East Antarctic Wilkes Land Continental Margin sediments. Global Planet. Change, 45(13):51-81. doi:10.1016/j.gloplacha.2004.09.010

Escutia, C., Eittreim, S.L., and Cooper, A.K., 1997. Cenozoic sedimentation on the Wilkes Land continental rise, Antarctica. In Ricci, C.A. (Ed.), The Antarctic Region: Geological Evolution and Processes. Proc. Int. Symp. Antarct. Earth Sci., 7:791-795.
Escutia, C., Eittreim, S.L., Cooper, A.K., and Nelson, C.H., 2000. Morphology and acoustic character of the Antarctic Wilkes Land turbidite systems: ice-sheet-sourced versus river-sourced fans. J. Sediment. Res., 70(1):84-93. doi:10.1306/2DC40900-0E47-11D78643000102C1865D

Escutia, C., Nelson, C.H., Acton, G.D., Eittreim, S.L., Cooper, A.K., Warnke, D.A., and Jaramillo, J.M., 2002. Current controlled deposition on the Wilkes Land continental rise, Antarctica. In Stow, D.A.V., Pudsey, C.J., Howe, J.A., Faugeres, J.-C., and Viana, A.R. (Eds.), Deep-Water Contourite Systems: Modern Drifts and Ancient Series, Seismic and Sedimentary Characteristics. Mem.Geol. Soc. London, 22(1):373-384. doi:10.1144/ GSL.MEM.2002.022.01.26

Escutia, C., Warnke, D., Acton, G.D., Barcena, A., Burckle, L., Canals, M., and Frazee, C.S., 2003. Sediment distribution and sedimentary processes across the Antarctic Wilkes Land margin during the Quaternary. Deep-Sea Res., Part II, 50(8-9):1481-1508. doi:10.1016/S09670645(03)00073-0

Exon, N.F., Kennett, J.P., Malone, M.J., et al., 2001. Proc. ODP, Init. Repts., 189: College Station, TX (Ocean Drilling Program). doi:10.2973/odp.proc.ir.189.2001

Exon et al., 2004. p. 7. from Leg 189 Synthesis. Exon, Kennett, and Malone. Sci. Results.

Ferraccioli, F., Coren, F., Bozzo, E., Zanolla, C., Gandolfi, S., Tabacco, I., and Frezzotti, M., 2001. Rifted(?) crust at the East Antarctic Craton margin: gravity and magnetic interpretation along a traverse across the Wilkes subglacial basin region. Earth Planet. Sci. Lett., 192(3):407-421. doi:10.1016/S0012-821X(01)00459-9

Ferraccioli, F., Jordan, T., Armadillo, E., Bozzo, E., Corr, H., Caneva, G., Robinson, C., and Tabacco, I., 2007. Exploring under the East Antarctic Ice Sheet with new aerogeophysical surveys over the Wilkes subglacial basin, the Trasantarctic Mountains and Dome C. In Cooper, A., Raymond, C., and the ISAES Editorial Team (Eds.), Antarctica: A Keystone in a Changing World-Online Proceedings for the Tenth International Symposium on Antarctic Earth Sciences. USGS Open-File Rep. 2007-1047:074. (Abstract)

Ferraccioli, F., Armadillo, E., Jordan, T., Bozzo, E., and Corr, H., 2009. Aeromagnetic exploration over the East Antarctic Ice Sheet: a new view of the Wilkes Subglacial Basin. Tectonophysics, 478(1-2):62-77. doi:10.1016/ j.tecto.2009.03.013

Florindo, F., Wilson, G.S., Roberts, A.P., Sagnotti, L., Verosub, K.L., 2005. Magnetostratigraphic chronology of a late Eocene to early Miocene glacimarine succession from Victoria Land Basin, Ross Sea, Antarctica. Global Planet. Change, 45(1-3):207-236. doi:10.1016/j.gloplacha.2004.09.009

Flower, B.P., and Kennett, J.P., 1994. The middle Miocene climatic transition: East Antarctic ice sheet development, deep ocean circulation, and global carbon cycling. Palaeogeogr., Palaeoclimatol., Palaeoecol., 108(34):537-555. doi:10.1016/0031-0182(94)90251-8

Gilli, A., Ariztegui, D., Anselmetti, F.S., McKenzie, J.A., Markgraf, V., Hajdas, I., and McCulloch, R.D., 2005. 
Mid-Holocene strengthening of the Southern Westerlies in South America-sedimentological evidences from Lago Cardiel, Argentina ( $\left.49^{\circ} \mathrm{S}\right)$. Global Planet. Change, 49(1-2):75-93. doi:10.1016/j.gloplacha.2005.05.004

Gradstein, F.M., Ogg, J.G., and Smith, A. (Eds.), 2004. A Geologic Time Scale 2004: Cambridge (Cambridge Univ. Press). http://cambridge.org/uk/catalogue/catalogue. asp? isbn=9780521781428

Grützner, J., Hillenbrand, C.-D., and Rebesco, M., 2005. Terrigenous flux and biogenic silica deposition at the Antarctic continental rise during the late Miocene to early Pliocene: implications for ice sheet stability and sea ice coverage. Global Planet. Change, 45(1-3):131149. doi:10.1016/j.gloplacha.2004.09.004

Hambrey, M.J., and McKelvey, B., 2000a. Major Neogene fluctuations of the East Antarctic ice sheet: stratigraphic evidence from the Lambert Glacier region. Geology, 28(10):887-890. doi:10.1130/ 0091-7613(2000) 28<887:MNFOTE $>2.0 . C O ; 2$

Hambrey, M.J., and McKelvey, B., 2000b. Neogene fjordal sedimentation on the western margin of the Lambert Graben, East Antarctica. Sedimentology, 47(4):577-607. doi:10.1046/j.1365-3091.2000.00308.x

Hambrey, M.J., Ehrmann, W.U., and Larsen, B., 1991. Cenozoic glacial record of the Prydz Bay continental shelf, East Antarctica. In Barron, J., Larsen, B., et al., Proc. ODP, Sci. Results, 119: College Station, TX (Ocean Drilling Program), 77-132. doi:10.2973/ odp.proc.sr.119.200.1991

Hambrey, M.J., Webb, P.-N., Harwood, D.M., and Krissek, L.A., 2003. Neogene glacial record from the Sirius Group of the Shackleton Glacier region, central Transantarctic Mountains, Antarctica. Geol. Soc. Am. Bull., 115(8):994-1015. doi:10.1130/B25183.1

Hampton, M.A., Eittreim, S.L., and Richmond, B.M., 1987. Post-breakup sedimentation on the Wilkes Land margin, Antarctica. In Eittreim, S.L., and Hampton, M.A. (Eds.), The Antarctic Continental Margin: Geology and Geophysics of Offshore Wilkes Land. Earth Sci. Ser. (N. Y.), 5A:75-87.

Harwood, D.M., and Webb, P.N., 1998. Glacial transport of diatoms in the Antarctic Sirius Group: Pliocene refrigerator. GSA Today, 8(4):1-8.

Hayes, D.E., Frakes, L.A., et al., 1975. Init. Repts. DSDP, 28: Washington, DC (U.S. Govt. Printing Office). doi:10.2973/dsdp.proc.28.1975

Hearty, P.J., Kindler, P., Cheng, H., and Edwards, R.L., 1999. $\mathrm{A}+20 \mathrm{~m}$ middle Pleistocene sea- level highstand (Bermuda and the Bahamas) due to partial collapse of Antarctic ice. Geology, 27(4):375-378. doi:10.1130/00917613(1999)027<0375:AMMPSL>2.3.CO;2

Hillenbrand, C.-D., and Ehrmann, W., 2005. Late Neogene to Quaternary environmental changes in the Antarctic Peninsula region: evidence from drift sediments. Global Planet. Change, 45(1-3):165-191. doi:10.1016/j.gloplacha.2004.09.006

Huber, M., Brinkhuis, H., Stickley, C.E., Döös, K., Sluijs, A., Warnaar, J., Schellenberg, S.A., and Williams, G.L., 2004. Eocene circulation of the Southern Ocean: was Antarctica kept warm by subtropical waters? Paleoceanography, 19(4):PA4026. doi:10.1029/2004PA001014
Huybrechts, P., 1993. Glaciological modelling of the Late Cenozoic East Antarctic Ice Sheet: stability or dynamism? Geograf. Ann., 75(4):221-238. doi:10.2307/ 521202

Ishihara, T., Tanahashi, M., Sato, M., and Okuda, Y., 1996. Preliminary report of geophysical and geological surveys of the west Wilkes Land margin. Proc. NIPR Symp. Antarct. Geosci., 9:91-108.

Kemp, E.M., Frakes, L.A., and Hayes, D.A., 1975. Paleoclimatic significance of diachronous biogenic facies, Leg 28, Deep Sea Drilling Project. In Hayes, D.E., Frakes, L.A., et al., Init. Repts. DSDP, 28: Washington, DC (U.S. Govt. Printing Office), 909-917. doi:10.2973/ dsdp.proc.28.135.1975

Kennett, J.P., 1977. Cenozoic evolution of Antarctic glaciation, the circum-Antarctic Ocean, and their impact on global paleoceanography. J. Geophys. Res., 82(27):38433860. doi:10.1029/JC082i027p03843

Kennett, J.P., and Hodell, D.A., 1993. Evidence for relative climate stability of Antarctica during the early Pliocene: a marine perspective. Geogr. Ann., 75A(4):205-220. doi:10.2307/521201

Kennett, J.P., and Hodell, D.A., 1995. Stability or instability of Antarctic ice sheets during warm climates of the Pliocene? GSA Today, 5(1):1-22.

Korte, M., and Constable, C.G., 2005. The geomagnetic dipole moment over the last 7000 years-new results from a global model. Earth Planet. Sci. Lett., 236(12):348-358. doi:10.1016/j.epsl.2004.12.031

Lamy, F., Hebbeln, D., Röhl, U., and Wefer, G., 2001. Holocene rainfall variability in southern Chile: a marine record of latitudinal shifts of the southern westerlies. Earth Planet. Sci. Lett., 185(3-4):369-382. doi:10.1016/ S0012-821X(00)00381-2

Leitchenkov, G.L., Guseva, Y.B., and Gandyukhin, V.V., 2007. Cenozoic environmental changes along the East Antarctic continental margin inferred from regional seismic stratigraphy. In Cooper, A., Raymond, C., and the ISAES Editorial Team (Eds.), Antarctica: A Keystone in a Changing World-Online Proceedings for the Tenth International Symposium on Antarctic Earth Sciences. USGS Open-File Rep., 2007-1047:005. doi:10.3133/of20071047.srp005

Leventer, A., Domack, E., Barkoukis, A., McAndrews, B., and Murray, J., 2002. Laminations from the Palmer Deep: a diatom-based interpretation. Paleoceanography, 17(3):8002. doi:10.1029/2001PA000624

Leventer, A., Domack, E., Dunbar, R., Pike, J., Stickley, C., Maddison, E., Brachfeld, S., Manley, P., and McClennen, C., 2006. Marine sediment record from the East Antarctic margin reveals dynamics of ice sheet recession. GSA Today, 16(12):4-10. doi:10.1130/GSAT01612A.1

Leventer, A., Domack, E.W., Ishman, S.E., Brachfeld, S., McClennen, C.E., and Manley, P., 1996. Productivity cycles of 200-300 years in the Antarctic Peninsula region: understanding linkages among the sun, atmosphere, oceans, sea ice, and biota. Geol. Soc. Am. Bull., 108(12):1626-1644. doi:10.1130/ 0016-7606(1996)108<1626:PCOYIT>2.3.CO;2 
Leventer, A., and Dunbar, R.B., 1988. Recent diatom record of McMurdo Sound, Antarctica: implications for history of sea ice extent. Paleoceanography, 3(3):259-274. doi:10.1029/PA003i003p00259

Leventer, A., Dunbar, R.B., and DeMaster, D.J., 1993. Diatom evidence for late Holocene climatic events in Granite Harbor, Antarctica. Paleoceanography, 8(3):373-386. doi:10.1029/93PA00561

Leventer, A., McClennen, C., and Shipboard Scientific Party, 2001. Coring Holocene Antarctic Ocean Sediments. NBP1-1 Postcruise Rep., U.S. Antarct. Prog.

Lewis, A.R., Marchant, D.R., Ashworth, A.C., Hemming S.R., and Machlus M.L., 2007. Major middle Miocene global climate change: evidence from East Antarctica and the Transantarctic Mountains. Geol. Soc. Am. Bull., 119(11):1449-1461. doi:10.1130/0016-

7606(2007)119[1449:MMMGCC]2.0.CO;2

Lisiecki, L.E., and Raymo, M.E., 2005. A Pliocene-Pleistocene stack of 57 globally distributed benthic $\delta^{18} \mathrm{O}$ records. Paleoceanography, 20(1):PA1003. doi:10.1029/ 2004PA001071

Lindstrom, D., and Tyler, D., 1984. Preliminary results of Pine Island and Thwaites glaciers study. Antarct. J. U. S., 19:53-55.

MacDonald, T.R., Ferrigno, J.G., Williams, R.S., Jr., and Luchitta, B.K., 1989. Velocities of Antarctic outlet glaciers determined from sequential Landsat images. Antarct. J. U. S., 24(5):105-106.

Macphail, M.K., and Truswell, E.M., 2004. Palynology of Site 1166, Prydz Bay, East Antarctica. In Cooper, A.K., O'Brien, P.E., and Richter, C. (Eds.), Proc. ODP, Sci. Results, 188: College Station, TX (Ocean Drilling Program), 1-43. doi:10.2973/odp.proc.sr.188.013.2004

Maddison, E.J., Pike, J., Leventer, A., Dunbar, R., Brachfeld, S., Domack, E.W., Manley, P., and McClennen, C., 2006. Post-glacial seasonal diatom record of the Mertz Glacier Polynya, East Antarctic. Mar. Micropaleontol., 60(1):6688. doi:10.1016/j.marmicro.2006.03.001

Mallinson, D.J., Flower, B., Hine, A., Brooks, G., and Molina Garza, R., 2003. Paleoclimate implications of high latitude precession-scale mineralogic fluctuations during early Oligocene Antarctic glaciation: the Great Australian Bight record. Glob. Planet. Change 39(34):257-269. doi:10.1016/S0921-8181(03)00119-X

Marsland, S.J., Bindoff, N.L., Williams, G.D., and Budd, W.F., 2004. Modeling water mass formation in the Mertz Glacier Polynya and Adélie depression, East Antarctica. J. Geophys. Res., 109(C11):C11003. doi:10.1029/ 2004JC002441

Massom, R.A., Hill, K.L., Lytle, V.I., Worby, A.P., Paget, M.J., and Allison, I., 2001. Effects of regional fast-ice and iceberg distributions on the behavior of the Mertz Glacier Polynya, East Antarctica. Ann. Glaciol., 33(1):391-398. doi:10.3189/172756401781818518

Massom, R.A., Jacka, K., Pook, M.J., Fowler, C., Adams, N., and Bindoff, N., 2003. An anomalous late-season change in the regional sea ice regime in the vicinity of the Mertz Glacier Polynya, East Antarctica. J. Geophys. Res., 109(C7):3212, doi:10.1029/2002JC001354
Mawson, D., 1940. Sedimentary rocks. Australas. Antarct. Exp. 1911-14, Ser. A, 4:347-367.

Mawson, D., 1942. Geographical narrative and cartography. Australas. Antarct. Exp. 1911-14, Ser. A, 1:1-364.

Michel, E., Crosta, X., and Shipboard Scientific Party, 2006. Les rapport de campagne à la mer à bord du Marion Dufresne-MD130/MD131 (IMAGES X). Institut Polaire Francais Paul-Émile Victor (IPEV).

Miller, K.G., Aubry, M.-P., Kahn, M.J., Melillo, A.J., Kent, D.V., and Berggren, W.A., 1985. Oligocene-Miocene biostratigraphy, magnetostratigraphy, and isotopic stratigraphy of the western North Atlantic. Geology,

13(4):257-261. doi:10.1130/

0091-7613(1985)13<257:OBMAIS>2.0.CO;2

Naish, T.R., Woolfe, K.J., Barrett, P.J., Wilson, G.S., Atkins, C., Bohaty, S.M., Bücker, C.J., Claps, M., Davey, F.J., Dunbar, G.B., Dunn, A.G., Fielding, C.R., Florindo, F., Hannah, M.J., Harwood, D.M., Henrys, S.A., Krissek, L.A., Lavelle, M., van der Meer, J., McIntosh, W.C., Niessen, F., Passchier, S., Powell, R.D., Roberts, A.P., Sagnotti, L., Scherer, R.P., Strong, C.P., Talarico, F., Verosub, K.L., Villa, G., Watkins, D.K., Webb, P.-N., and Wonik, T., 2001. Orbitally induced oscillations in the East Antarctic ice sheet at the Oligocene/Miocene boundary. Nature (London, U. K.), 413:719-723. doi:10.1038/35099534

Naish, T., Powell, R., Levy, R., Wilson, G., Scherer, R., Talarico, F., Krissek, L., Niessen, F., Pompilio, M., Wilson, T., Carter, L., DeConto, R., Huybers, P., McKay, R., Pollard, D., Ross, J., Winder, D., Barrett, P., Browne, G., Cowan, E., Crampton, J., Dunbar, G., Dunbar, N., Florindo, F., Gebhardt, C., Graham, I., Hannah, M., Hansaraj, D., Harwood, D., Helling, D., Henrys, S., Hinnov, L., Kuhn, G., Kyle, P., Läufer, A., Maffioli, P., Magens, D., Mandernack, K., McIntosh, W., Millan, C., Morin, R., Ohneiser, C., Paulsen, T., Persico, D., Raine, I., Reed, J., Riesselman, C., Sagnotti, L., Schmitt, D., Sjunneskog, C., Strong, P., Taviani, M., Vogel, S., Wilch, T., and Williams, T., 2009. Obliquity-paced Pliocene West Antarctic ice sheet oscillations. Nature (London, U. K.), 458:322328. doi:10.1038/nature07867

Nesbitt, H.W., and Young, G.M., 1982. Early Proterozoic climates and plate motions inferred from major element chemistry of lutites. Nature (London, U.K.), 299(5885):715-717. doi:10.1038/299715a0

O'Brien, P.E., Cooper, A.K., Richter, C., et al., 2001. Proc. ODP, Init. Repts., 188: College Station, TX (Ocean Drilling Program). doi:10.2973/odp.proc.ir.188.2001

O'Brien, P.E., and Stagg, H.M.J., 2007. Tectonic elements of the continental margin of East Antarctica, $38^{\circ}-164^{\circ} \mathrm{E}$. In Cooper, A., Raymond, C., and the ISAES Editorial Team (Eds.), Antarctica: A Keystone in a Changing World: Online Proceedings for the Tenth International Symposium on Antarctic Earth Sciences. USGS Open-File Rep., 20071047:085.

Pagani, M., Zachos, J.C., Freeman, K.H., Tipple, B., and Bohaty, S., 2005. Marked decline in atmospheric carbon dioxide concentrations during the Paleogene. Science, 309(5734):600-603. doi:10.1126/science.1110063

Pälike, H., Norris, R.D., Herrle, J.O., Wilson, P.A., Coxall, H.K., Lear, C.H., Shackleton, N.J., Tripati, A.K., and 
Wade, B.S., 2006. The heartbeat of the Oligocene climate system. Science, 314(5807):1894-1898.

doi:10.1126/science.1133822

Passchier, S., O’Brien, P.E., Damuth, J.E., Januszczak, N., Handwerger, D.A., and Whitehead, J.M., 2003. Pliocene-Pleistocene glaciomarine sedimentation in eastern Prydz Bay and development of the Prydz trough-mouth fan, ODP Sites 1166 and 1167, East Antarctica. Mar. Geol.,199(3-4):279-305. doi:10.1016/S00253227(03)00160-9

Passchier, S., and Krissek, L.A., 2008. Oligocene-Miocene Antarctic continental weathering record and paleoclimatic implications, Cape Roberts drilling Project, Ross Sea, Antarctica. Palaeogeogr., Palaeoclimatol., Palaeoecol., 260(1-2):30-40. doi:10.1016/j.palaeo.2007.08.012

Payne, R.R., and Conolly, J.R., 1972. Turbidite sedimentation off the Antarctic continent. Antarct. Res. Ser., 19:349-364.

Piper, D.J.W., and Brisco, C.B., 1975. Deep-water continental-margin sedimentation, DSDP Leg 28, Antarctica. In Hayes, D.E., Frakes, L.A., et al., Init. Repts. DSDP, 28: Washington, DC (U.S. Govt. Printing Office), 727-755. doi:10.2973/dsdp.proc.28.121.1975

Pollard, D., and DeConto, R.M., 2009. Modelling West Antarctic ice sheet growth and collapse through the past five million years. Nature (London, U. K.), 458(7236):329-332. doi:10.1038/nature07809

Powell, R.D., and Cooper, J.M., 2002. A sequence stratigraphic model for temperate, glaciated continental shelves. In Dowdeswell, J.A., and Ó Cofaigh, C. (Eds.), Glacier-Influenced Sedimentation on High Latitude Continental Margins: Ancient and Modern. Spec. Publ.- Geol. Soc. London, 203:215-244.

Rebesco, M., Camerlenghi, A., Geletti, R., and Canals, M., 2006. Margin architecture reveals the transition to the modern Antarctic ice sheet (AIS) ca. 3 Ma. Geology, 34(4):301-304. doi:10.1130/G22000.1

Rintoul, S., 1998. On the origin and influence of Adélie Land Bottom Water. In Jacobs, S.S., and Weiss, R.F. (Eds.), Ocean, Ice and Atmosphere: Interactions at the Antarctic Continental Margin. Antarct. Res. Ser., 75:151-172.

Sato, S., Asakura, N., Saki, T., Oikawa, N., and Kaneda, Y., 1984. Preliminary results of geological and geophysical surveys in the Ross Sea and in the Dumont d'Urville Sea, off Antarctica. Mem.-Natl. Inst. Polar Res., 33:6692.

Sayers, J., Symonds, P.A., Direen, N.G., and Bernardel, G., 2001. Nature of the continent-ocean transition on the non-volcanic rifted margin of the central Great Australian Bight. In Wilson, R.C.L., Whitmarsh, R.B., Taylor, B., and Froitzheim, N. (Eds.), Non-volcanic Rifting of Continental Margins: A Comparison of Evidence from Land and Sea. Geol. Soc. Spec. Publ., 187(1):51-76. doi:10.1144/ GSL.SP.2001.187.01.04

Shevenell, A., Domack, E.W., and Kernan, G.M., 1996. Record of Holocene paleoclimate change along the Antarctic Peninsula: evidence from glacial marine sediments, Lallemand Fjord. Pap.-Proc. R. Soc. Tas, 130:5564.
Shevenell, A.E., and Kennett, J.P., 2002. Antarctic Holocene climate change: a benthic foraminiferal stable isotope record from Palmer Deep. Paleoceanography, 17(2):8000. doi:10.1029/2000PA000596

Siegert, M.J., Barrett, P., DeConto, R., Dunbar, R., Cofaigh, C.O., Passchier, S., and Naish, T., 2008. Recent advances in understanding Antarctic climate evolution. Antarct. Sci., 20(4):313-325. doi:10.1017/S0954102008000941

Stagg, H.M.J., Colwell, J.B., Direen, N.G., O’Brien, P.E., Brown, B.J., Bernardel, G., Borissova, I., Carson, L., and Close, D.B., 2004. Geological Framework of the Continental Margin in the Region of the Australian Antarctic Territory: Canberra (Geosci. Australia)

Stickley, C.E., Brinkhuis, H., Schellenberg, S.A., Sluijs, A., Röhl, U., Fuller, M., Grauert, M., Huber, M., Warnaar, J., and Williams, G.L., 2004. Timing and nature of the deepening of the Tasmanian Gateway. Palaeoceanography, 19:PA4027. doi:10.1029/2004PA001022

Stickley, C.E., Pike, J., Leventer, A., Dunbar, R., Domack, E.W., Brachfeld, S., Manley, P., and McClennan, C., 2005. Deglacial ocean and climate seasonality in laminated diatom sediments, Mac.Robertson Shelf, Antarctica. Palaeogeogr., Palaeoclimatol., Palaeoecol., 227(4): 290-310. doi:10.1016/j.palaeo.2005.05.021

Stroeven, A.P., Burckle, L.H., Kleman, J., and Prentice, M.L., 1998. Atmospheric transport of diatoms in the Antarctic Sirius Group: Pliocene deep freeze. GSA Today, 8(4):1-5.

Tanahashi, M., Eittreim, S., and Wannesson, J., 1994. Seismic stratigraphic sequences of the Wilkes Land margin. Terra Antart., 1(2):391-393.

Tanahashi, M., Ishihara, T., Yuasa, M., Murakami, F., and Nishimura, A., 1997. Preliminary report of the TH95 geological and geophysical survey results in the Ross Sea and the Dumont d'Urville Sea. Proc. NIPR Symp. Antarct. Geosci., 10:36-58.

Ten Brink, U.S., and Cooper, A.K., 1992. Modeling the bathymetry of Antarctic continental margins. In Yoshida, Y., Kaminuma, K., and Shiraishi, K. (Eds.), Recent Progress in Antarctic Earth Science: Tokyo (Terra Publ.), 763-772.

Theissen, K.M., Dunbar, R.B., Rowe, H.D., and Mucciarone, D.A., 2008. Multidecadal- to century-scale arid episodes on the northern Altiplano during the middle Holocene. Palaeogeogr., Palaeoclimatol., Palaeoecol., 257(4):361-376. doi:10.1016/j.palaeo.2007.09.011

Tsumuraya, Y., Tanahashi, M., Saki, T., Machihara, T., and Asakura, N., 1985. Preliminary report of the marine geophysical and geological surveys off Wilkes Land, Antarctica in 1983-1984. Mem. Natl. Inst. Polar Res., Spec. Issue (Jpn.), 37:48-62.

Turner, J., Comiso, J.C., Marshall, G.J., Lachlan-Cope, T.A., Bracegirdle, T., Maksym, T., Meredith, M.P., Wang, Z., and Orr, A., 2009. Non-annular atmospheric circulation change induced by stratospheric ozone depletion and its role in the recent increase of Antarctic sea ice extent. Geophys. Res. Lett., 36(8):L08502. doi:10.1029/ 2009GL037524

Van Simaeys, S., Brinkhuis, H., Pross, J., Williams, G.L., and Zachos, J.C., 2005. Arctic dinoflagellate migrations 
mark the strongest Oligocene glaciations. Geology, 33(9):709-712. doi:10.1130/G21634.1

Veevers, J.J., 1987. The conjugate continental margins of Antarctica and Australia. In Eittreim, S.L., and Hampton, M.A. (Eds.), The Antarctic Continental Margin: Geology and Geophysics of Offshore Wilkes Land. Earth Sci. Ser. (N. Y.), 5A:45-73.

Wade, B.S., and Pälike, H., 2004. Oligocene climate dynamics. Paleoceanography, 19(4)PA4019. doi:10.1029/ 2004PA001042

Wannesson, J., 1990. Geology and petroleum potential of the Adelie Coast margin, East Antarctica. In St. John, B. (Ed.), Antarctica as an Exploration Frontier: Hydrocarbon Potential, Geology, and Hazards. AAPG Stud. Geol., 31:77-87.

Wannesson, J., Pelras, M., Petitperrin, B., Perret, M., and Segoufin, J., 1985. A geophysical transect of the Adélie Margin, East Antarctica. Mar. Pet. Geol., 2(3):192-200. doi:10.1016/0264-8172(85)90009-1

Webb, P.-N., Harwood, D.M., Mabin, M.G.C., and McKelvey, B.C., 1996. A marine and terrestrial Sirius Group succession, middle Beardmore Glacier-Queen Alexandra Range, Transantarctic Mountains, Antarctica. Mar. Micropaleontol., 27(1-4):273-297. doi:10.1016/03778398(95)00066-6

Whitehead, J.M., and Bohaty, S.M., 2003. Pliocene summer sea surface temperature reconstruction using silicoflagellates from Southern Ocean ODP Site 1165. Paleoceanography, 18(3):1075. doi:10.1029/2002PA000829

Whitehead, J.M., Harwood, D.M., McKelvey, B.C., Hambrey, M.J., and McMinn, A., 2004. Diatom biostratigraphy of the Cenozoic glaciomarine Pagodroma Group, northern Prince Charles Mountains, East Antarctica.
Aust. J. Earth Sci., 51(4):521-547. doi:10.1111/j.14000952.2004.01072.x

Whitehead, J.M., Harwood, D.M., and McMinn, A., 2003. Ice-distal upper Miocene marine strata from inland Antarctica. Sedimentology, 50(3):531-552. doi:10.1046/ j.1365-3091.2003.00563.x

Williams, G.D., Bindoff, N.L., Marsland, S.J., and Rintoul, S.R., 2008. Formation and export of dense shelf water from the Adélie Depression, East Antarctica. J. Geophys. Res., 113(C4):C04039. doi:10.1029/2007JC004346

Wise, S.W., Jr., Breza, J.R., Harwood, D.M., and Wei, W., 1991. Paleogene glacial history of Antarctica. In Müller, D.W., McKenzie, J.A., and Weissert, H. (Eds.), Controversies in Modern Geology: Evolution of Geological Theories in Sedimentology, Earth History and Tectonics: Cambridge (Cambridge Univ. Press), 133-171.

Zachos, J.C., Dickens, G.R., and Zeebe, R.E., 2008. An early Cenozoic perspective on greenhouse warming and carbon-cycle dynamics. Nature (London, U. K.), 451(7176):279-283. doi:10.1038/nature06588

Zachos, J.C., Flower, B.P., and Paul, H., 1997. Orbitally paced climate oscillations across the Oligocene/Miocene boundary. Nature (London, U. K.), 388(6642):567570. doi:10.1038/41528

Zachos, J., Pagani, M., Sloan, L., Thomas, E., and Billups, K., 2001. Trends, rhythms, and aberrations in global climate $65 \mathrm{Ma}$ to present. Science, 292(5517):686-693. doi:10.1126/science.1059412

Zhang, J., 2007. Increasing Antarctic sea ice under warming atmospheric and oceanic conditions. J. Clim., 20(11):2515-2529. doi:10.1175/JCLI4136.1

Publication: 2 July 2011 MS 318-101 
Figure F1. Updated Cenozoic $\mathrm{pCO}_{2}$ and stacked deep-sea benthic foraminifer oxygen isotope curve for 0 to $65 \mathrm{Ma}$. Updated from Zachos et al. (2008) and converted to the Gradstein timescale (Gradstein et al., 2004). Mi-1 = Miocene isotope Event 1, Oi-1 = Oligocene isotope Event 1, ETM2 = Eocene Thermal Maximum 2, PETM = Paleocene/Eocene Thermal Maximum, ETM1 = Eocene Thermal Maximum 1.
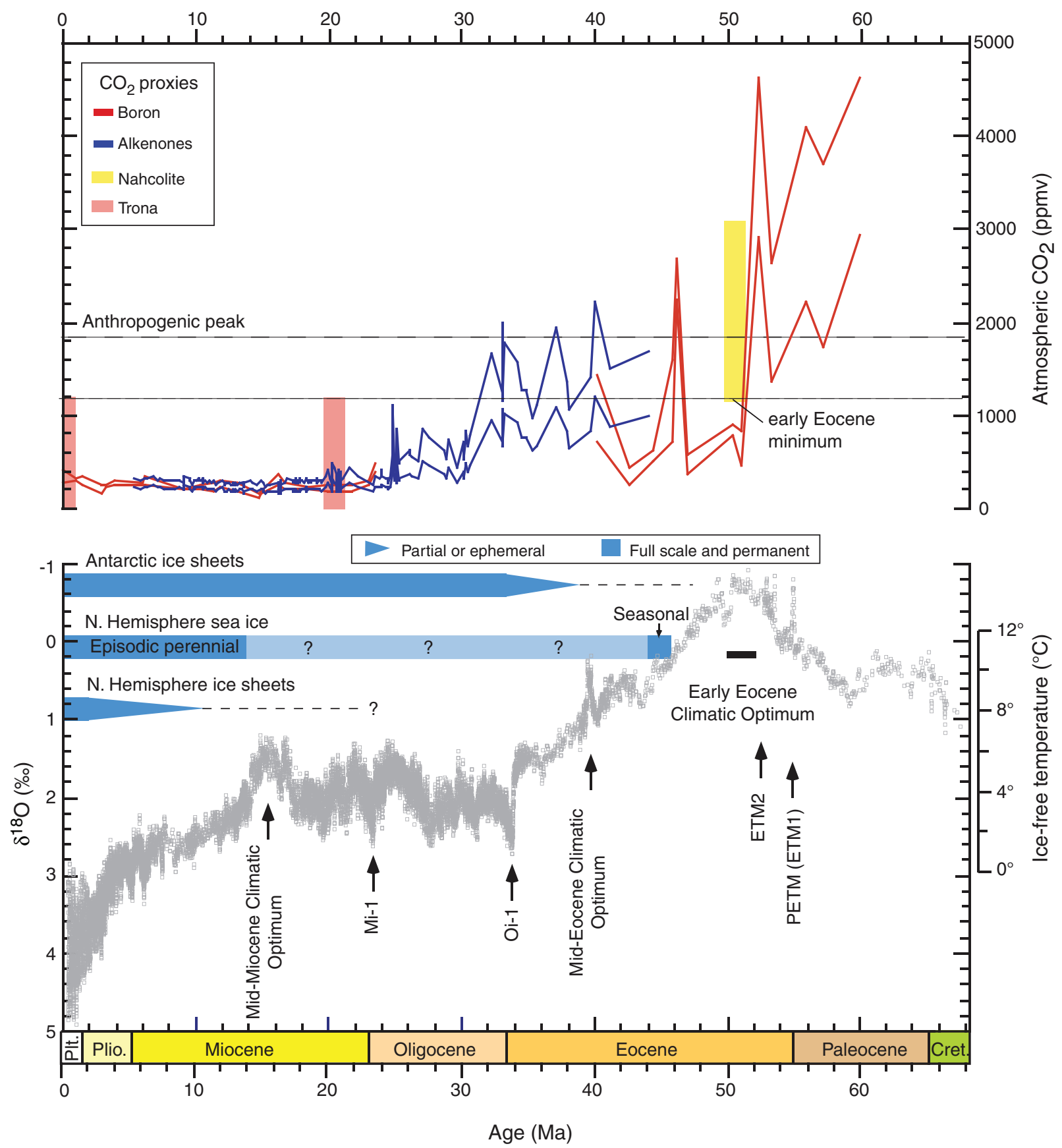
Figure F2. Simulated initiation of East Antarctic glaciation in the earliest Oligocene using a coupled GCM-ice sheet model (from DeConto and Pollard, 2003a). These results are principally forced by gradual lowering of atmospheric levels of $\mathrm{CO}_{2}$ concentration in the simulated atmosphere. Note that the glaciation takes place in a "two-step" fashion reminiscent of the two-step $\delta^{18} \mathrm{O}$ increase recorded in benthic foraminiferal carbonates across the Eocene-Oligocene transition (e.g., Coxall et al., 2005). The first step results in glaciation in the Antarctic continental interior, discharging mainly through the Lambert Graben (LG) to Prydz Bay (PB). The second step results in the initial connection and subsequent rapid expansion of the ice sheet, reaching sea level in the Wilkes Land $(\mathrm{WL})$ at a later stage. PAL = Preinustrial Atmospheric Level.

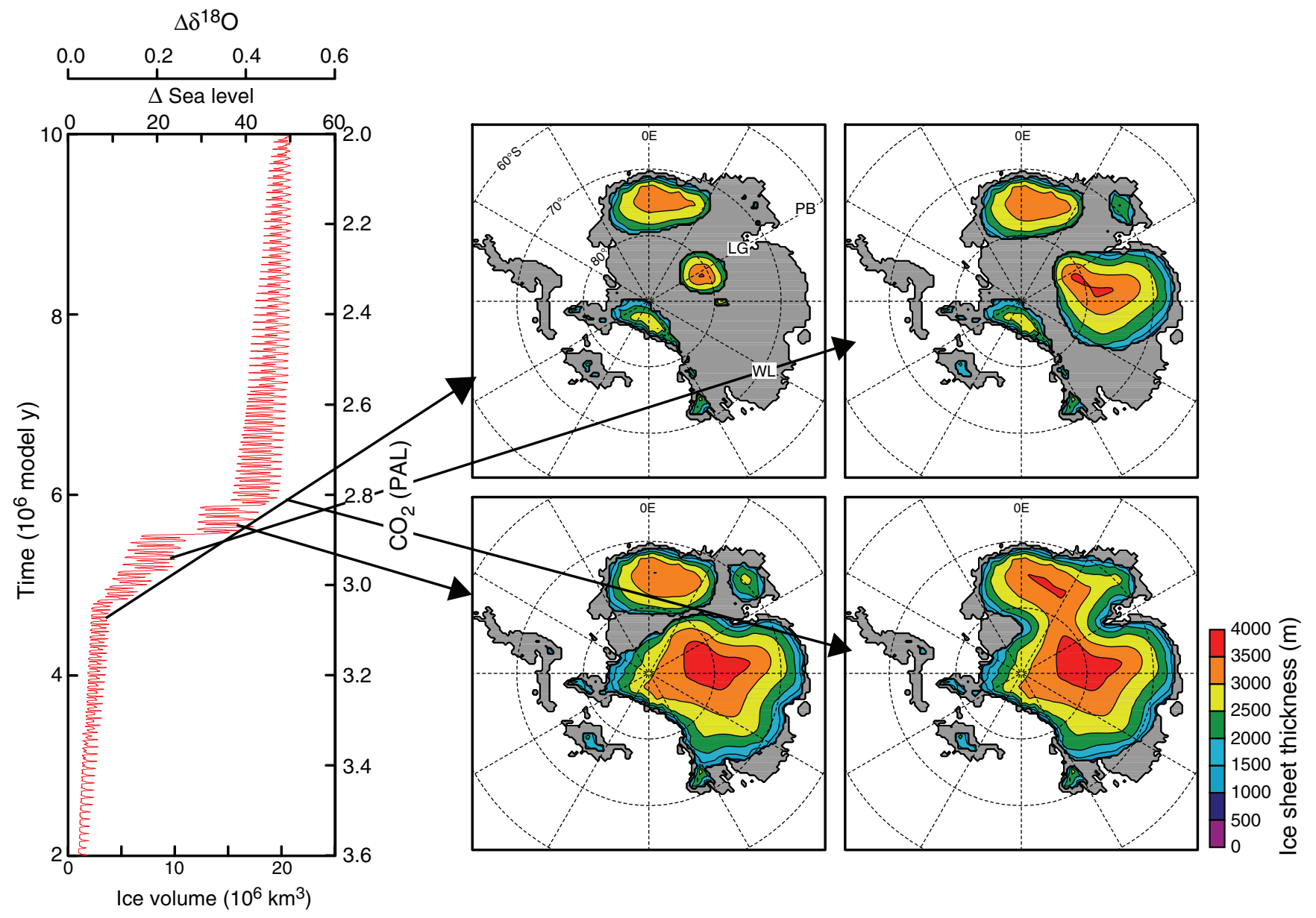


Figure F3. Earth's temperature variability during the last 80 m.y. based on reconstructions from deep-marine oxygen isotope records. Future atmospheric temperature scenarios, based on Intergovernmental Panel on Climate Change (2007, www.ipcc.ch/) greenhouse trace gas forecasts, are shown at top of diagram.

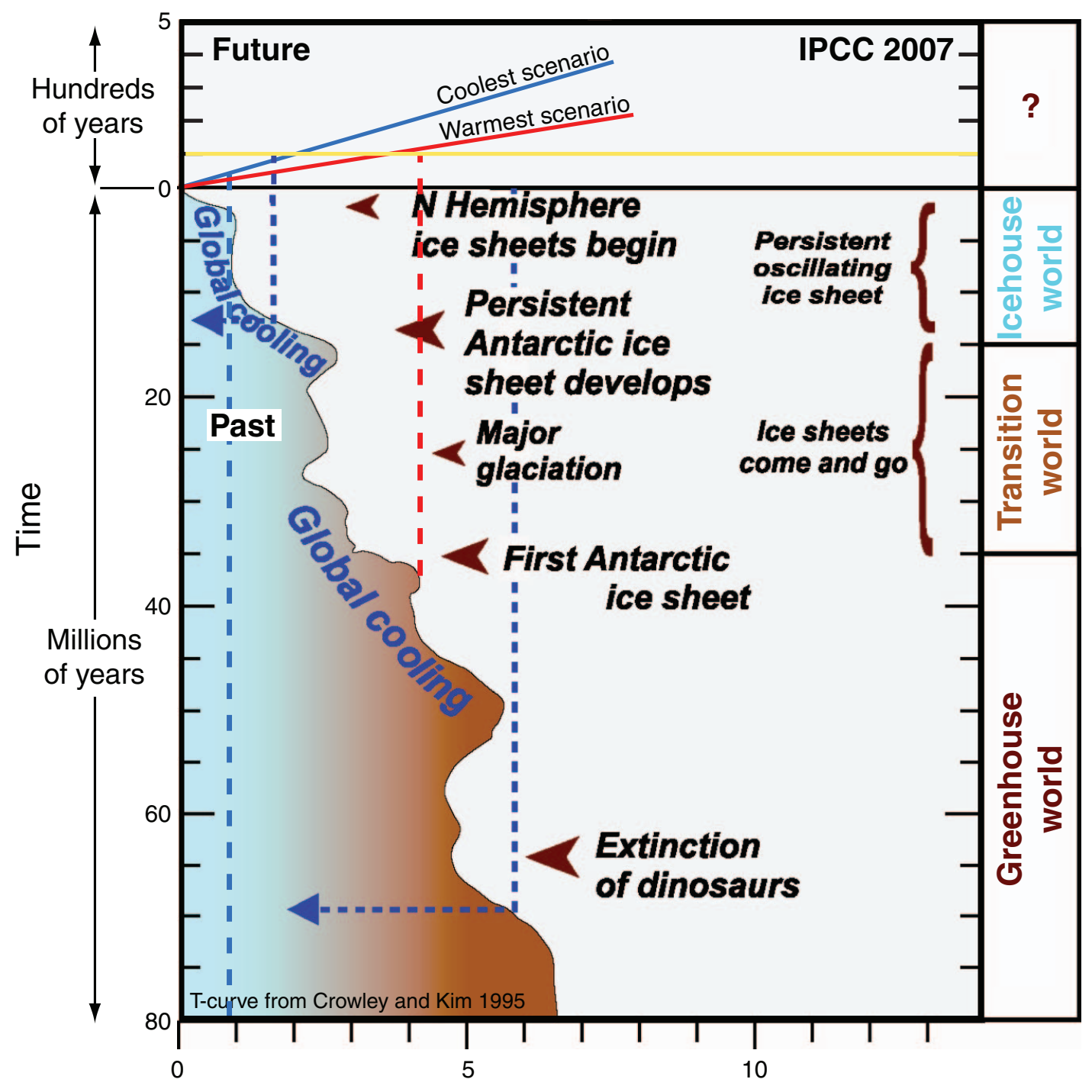

Change in global temperature from present $\left({ }^{\circ} \mathrm{C}\right)$ 
Figure F4. Antarctic drainage patterns of the West Antarctic Ice Sheet (WAIS) and the East Antarctic Ice Sheet (EAIS) from the interior to the coast. Red = areas of fast flowing ice streams. Also shown is the Expedition 318 drilling area, which partly drains the Wilkes subglacial basin, where the EAIS is partly grounded below sea level.

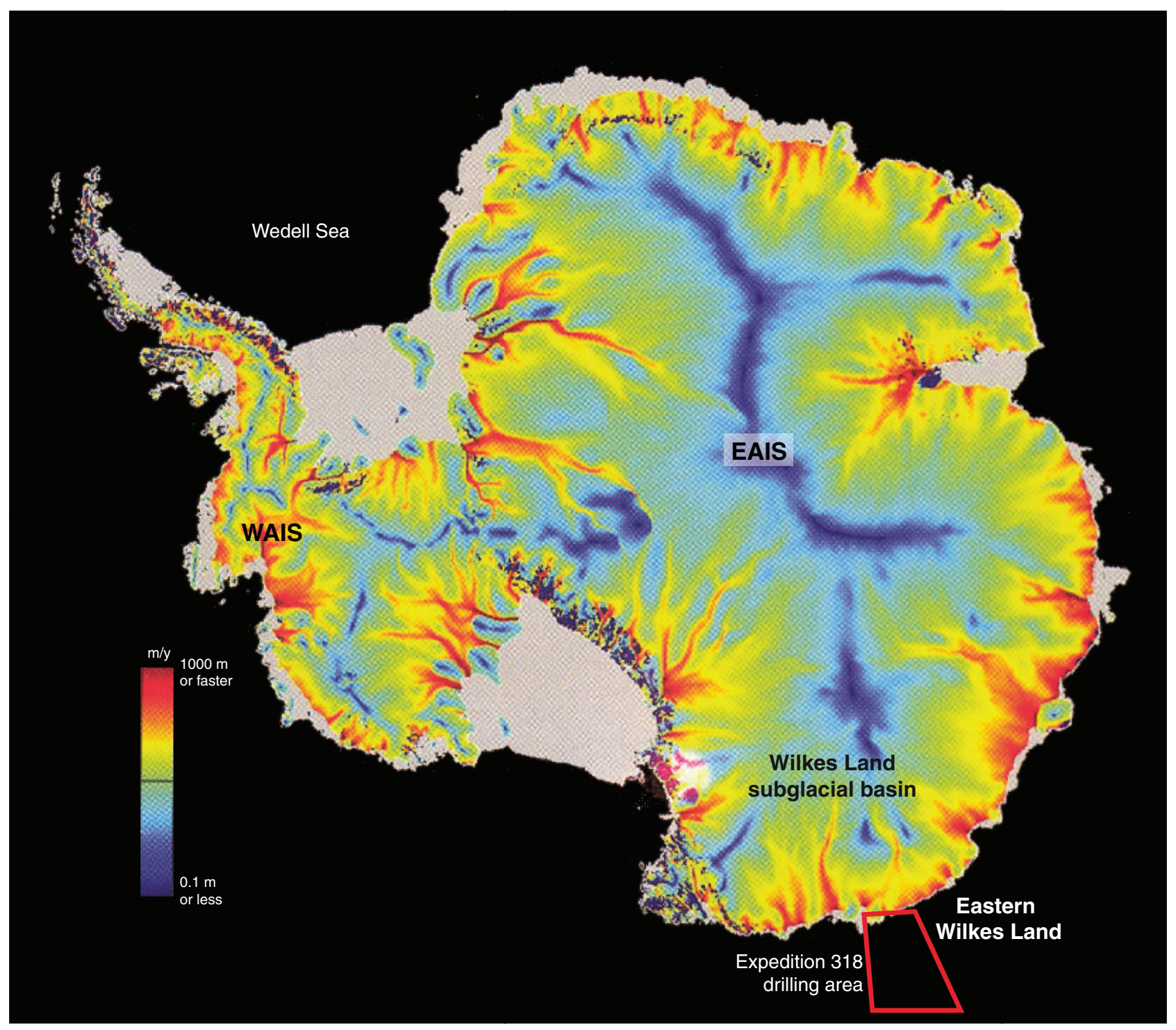


Figure F5. Aeromagnetic interpretation in the Wilkes subglacial basin. New subglacial topography map for the Wilkes subglacial basin and adjacent Trans Antarctic Mountains derived from airborne radar data is displayed over a new bedrock topography map obtained by combining the new data with previous airborne radar data compiled within BEDMAP (Ferraccioli et al., 2009).

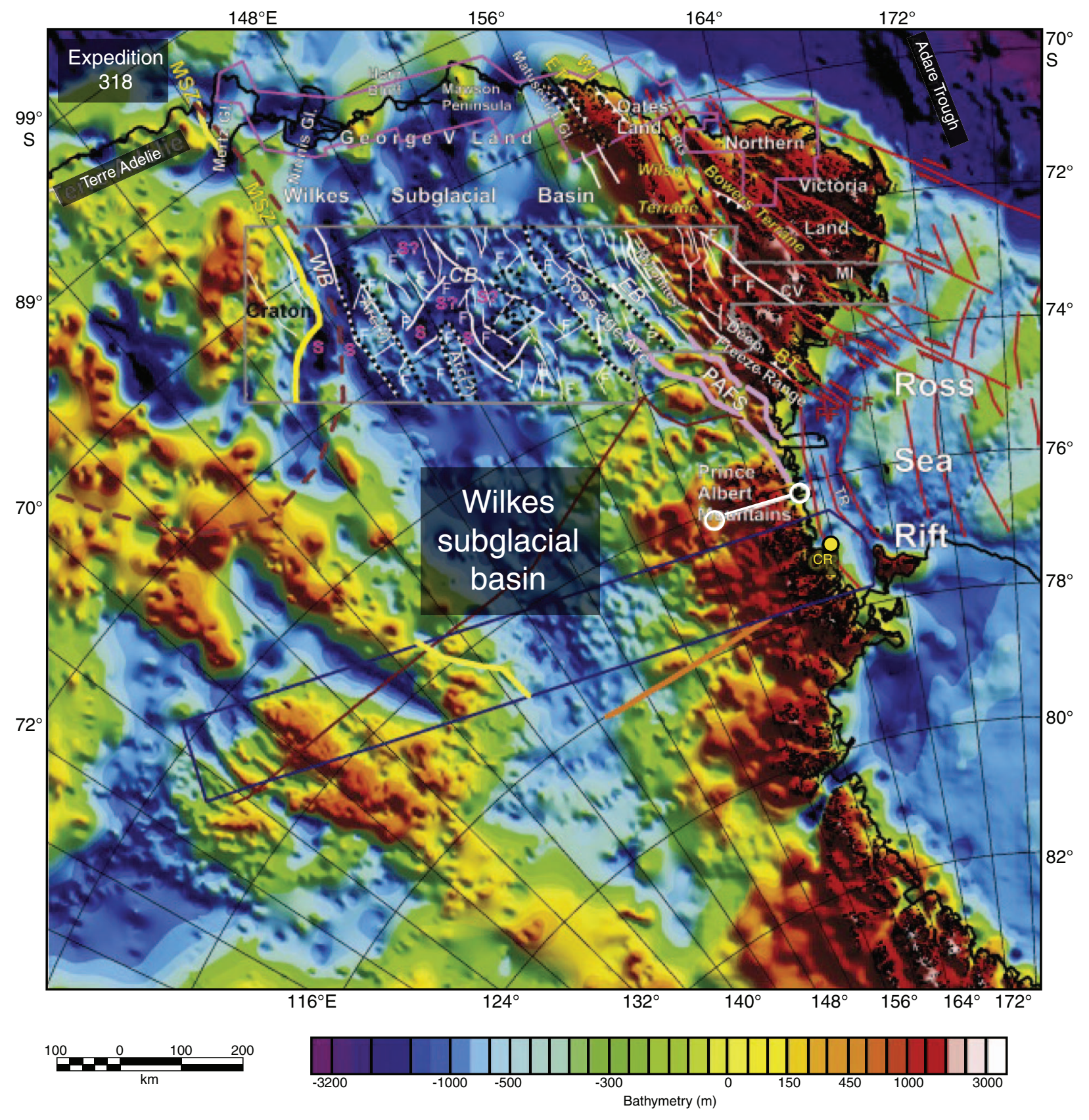


Figure F6. Detailed bathymetry of most of area drilled during Expedition 318. The irregular morphology of the continental shelf is characterized by several $>1000 \mathrm{~m}$ deep inner-shelf basins (Site U1357), erosional troughs extending from these basins to the shelf edge (Site U1358), and shallow banks adjacent to the troughs (Site U1360). The slope is incised by numerous canyons that in the continental rise evolve to channel-levee complexes (Sites U1356, U1359, and U1361).

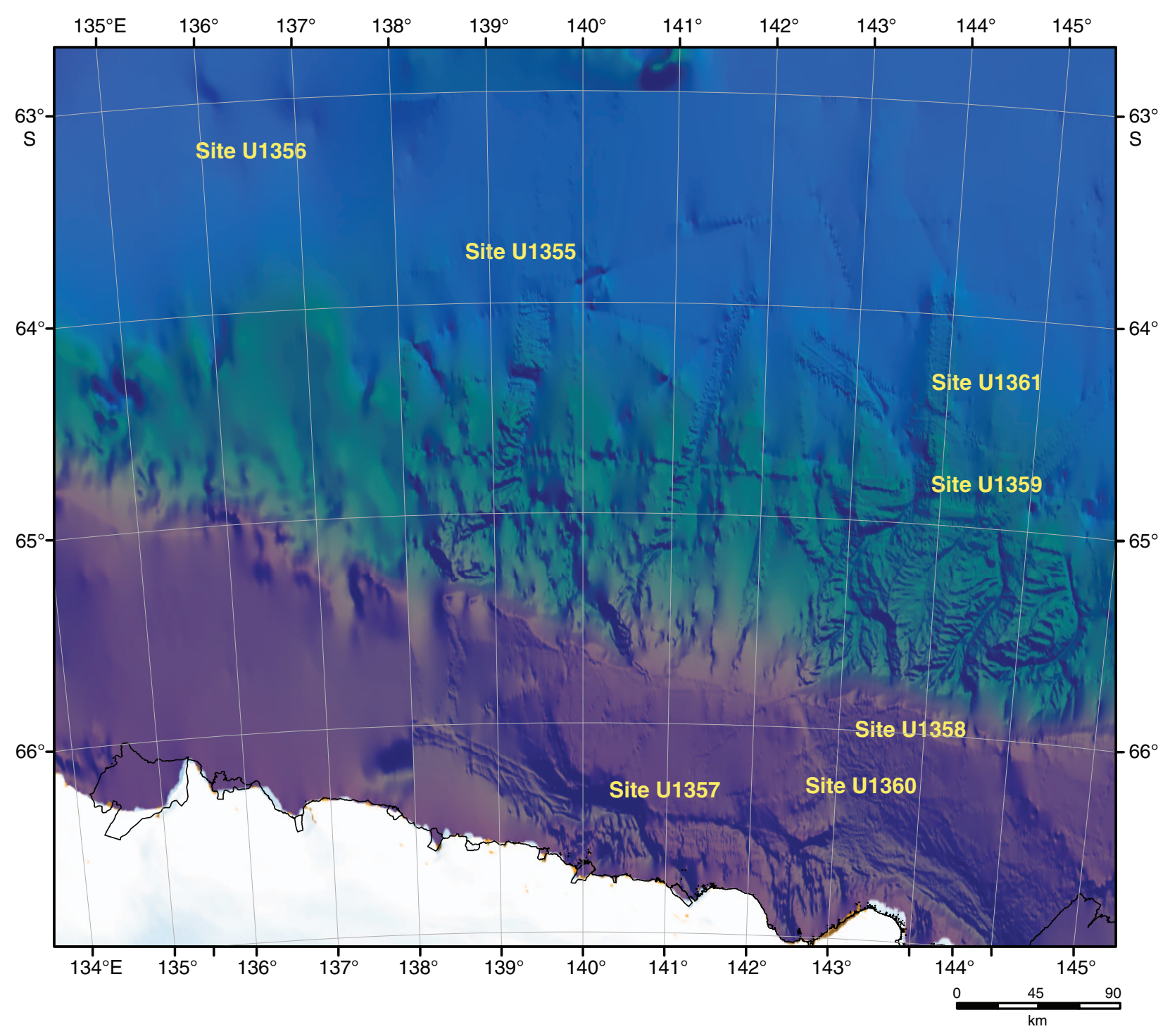


Figure F7. Uninterpreted and interpreted multichannel seismic reflection Profile IFP-107 across the Wilkes Land shelf and continental slope and base of slope. Topset strata form the banks that are adjacent to the troughs filled with foreset strata. The two main regional erosional unconformities in this margin are shown in the interpreted profile. Unconformity WL-U3 is interpreted to separate preglacial strata below from glacial strata above. Unconformity WL-U8 is interpreted to mark a change in the glacier regime possibly coinciding with the transition from wet-based to a cold-based more persistent ice sheet.
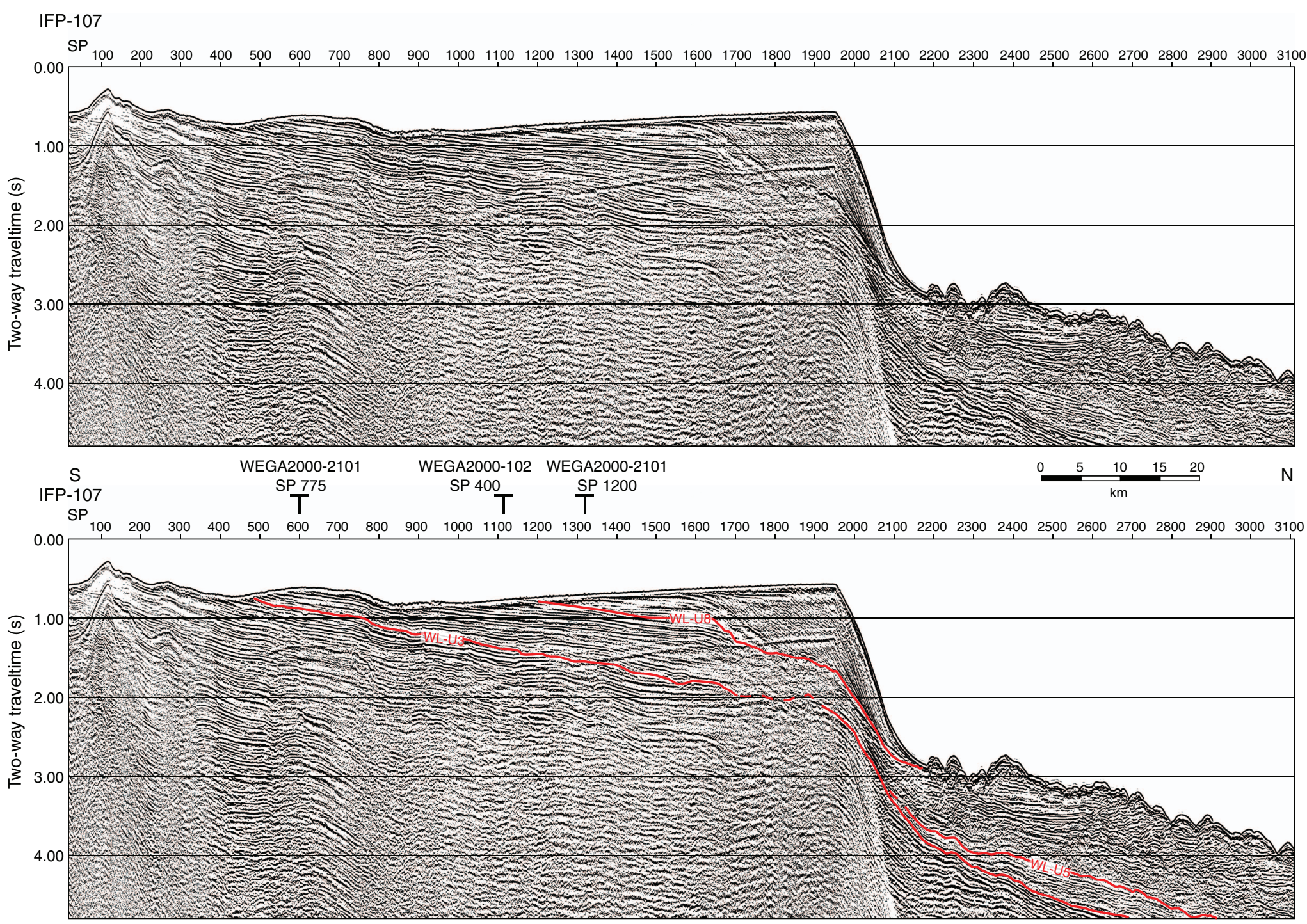
Figure F8. Interpreted and uninterpreted high-resolution multichannel seismic Profile WEGA W30 across the continental rise. Interpretation after Donda et al. (2003). This profile shows the upsection increase in the energy of the depositional environment above unconformity WL-U3 as a response to margin progradation. Note that the high-volume of sediment supply to the continental rise takes place between unconformities WLU5 and WL-U7. Above unconformity WL-U7, a decrease in the sediment supply to the continental rise corresponding with a shift in depocenters to the base of the slope is apparent.

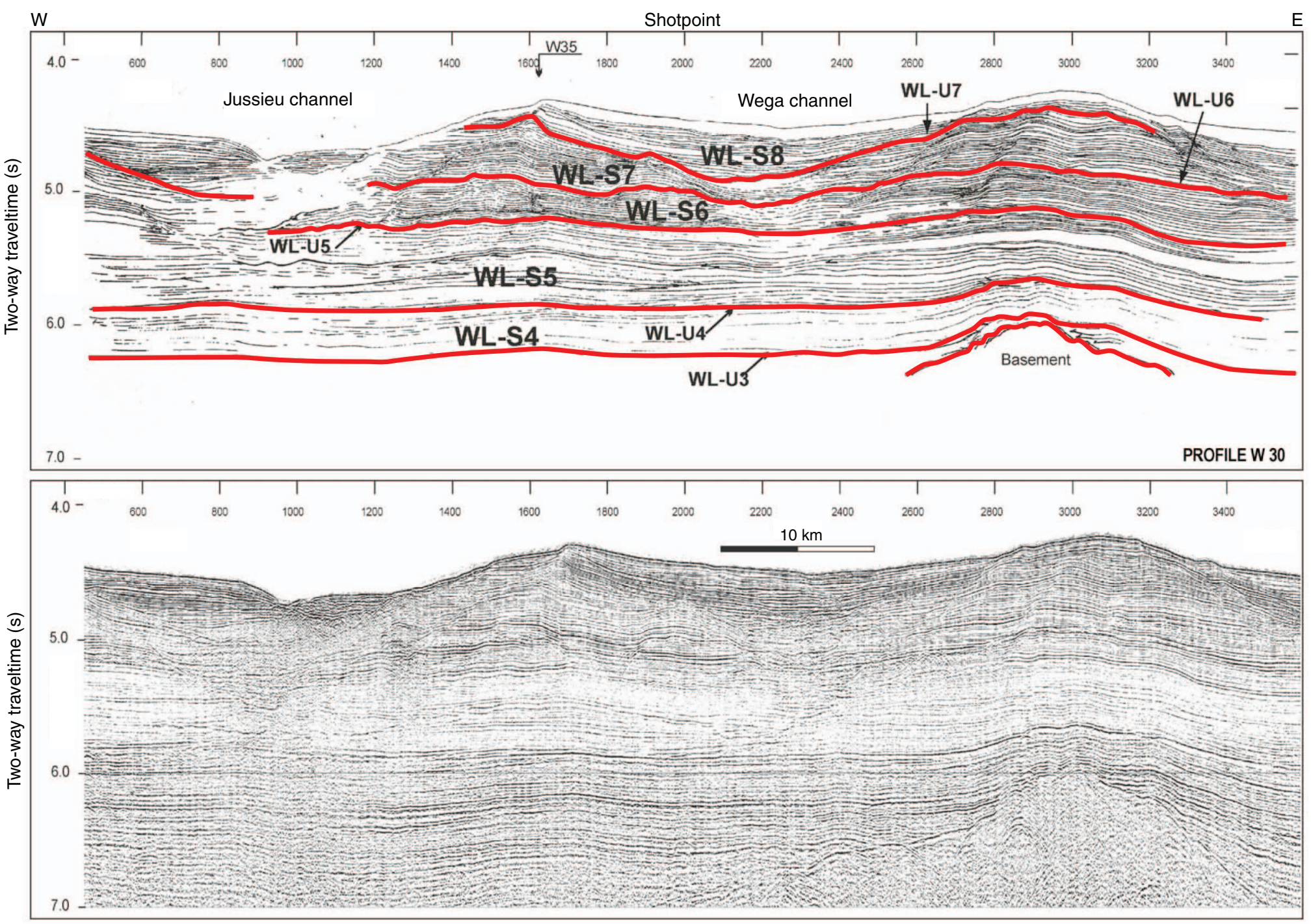


Figure F9. A. Bathymetric map of eastern Wilkes Land margin showing the location of Site U1357 and other Expedition 318 drill sites. Contour interval $=250 \mathrm{~m}$. Box $=$ approximate area of B. B. Bathymetric map of eastern Wilkes Land margin showing location of Site U1357 (black circle) and areas north and west of Adélie Basin.
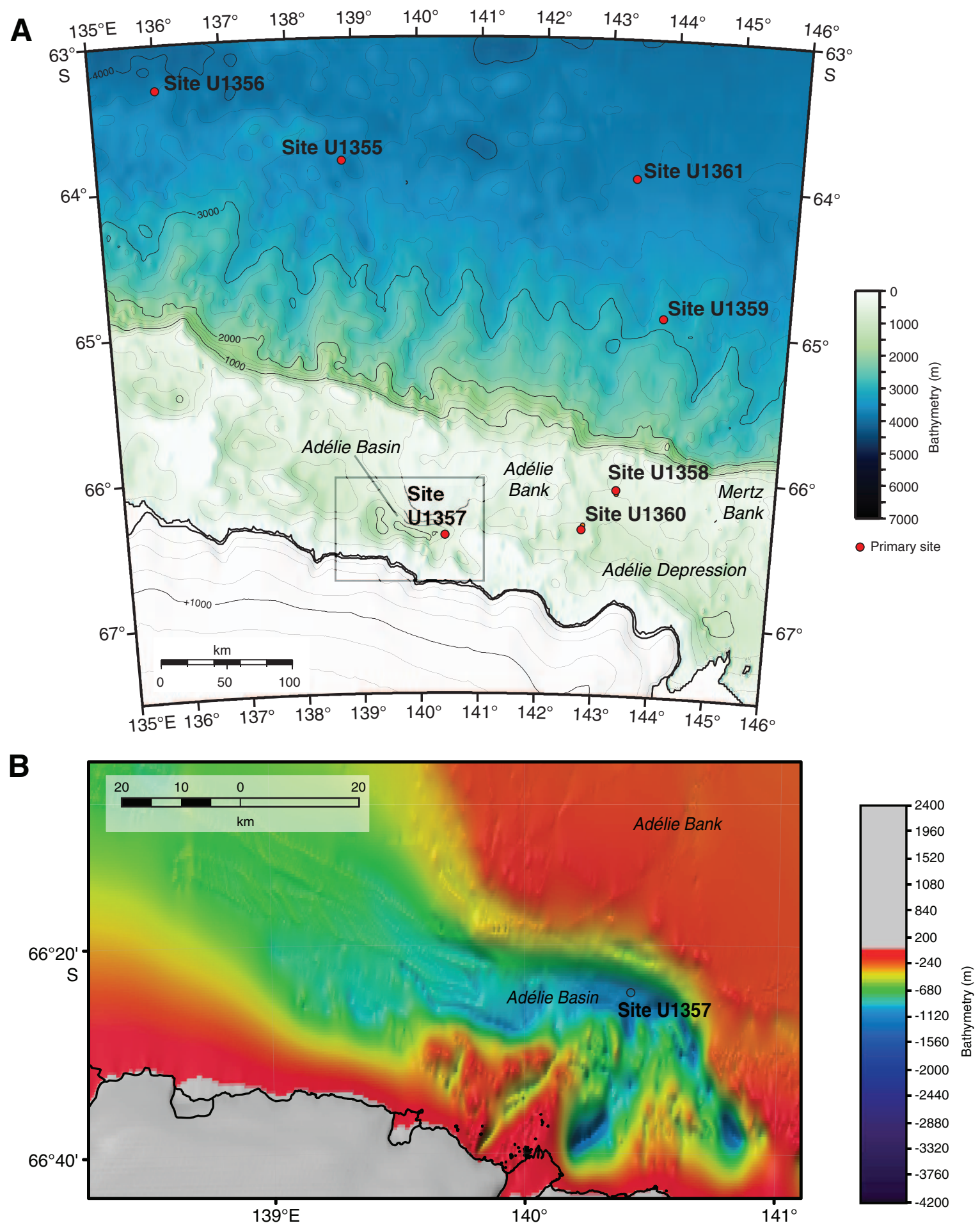
Figure F10. Swath bathymetry map of Adélie Basin in the vicinity of Site U1357. Circle = location of Site U1357. Bold black line = location of ODEC 2000 single-channel seismic line shown in Figure F11. Contour interval = $50 \mathrm{~m}$.

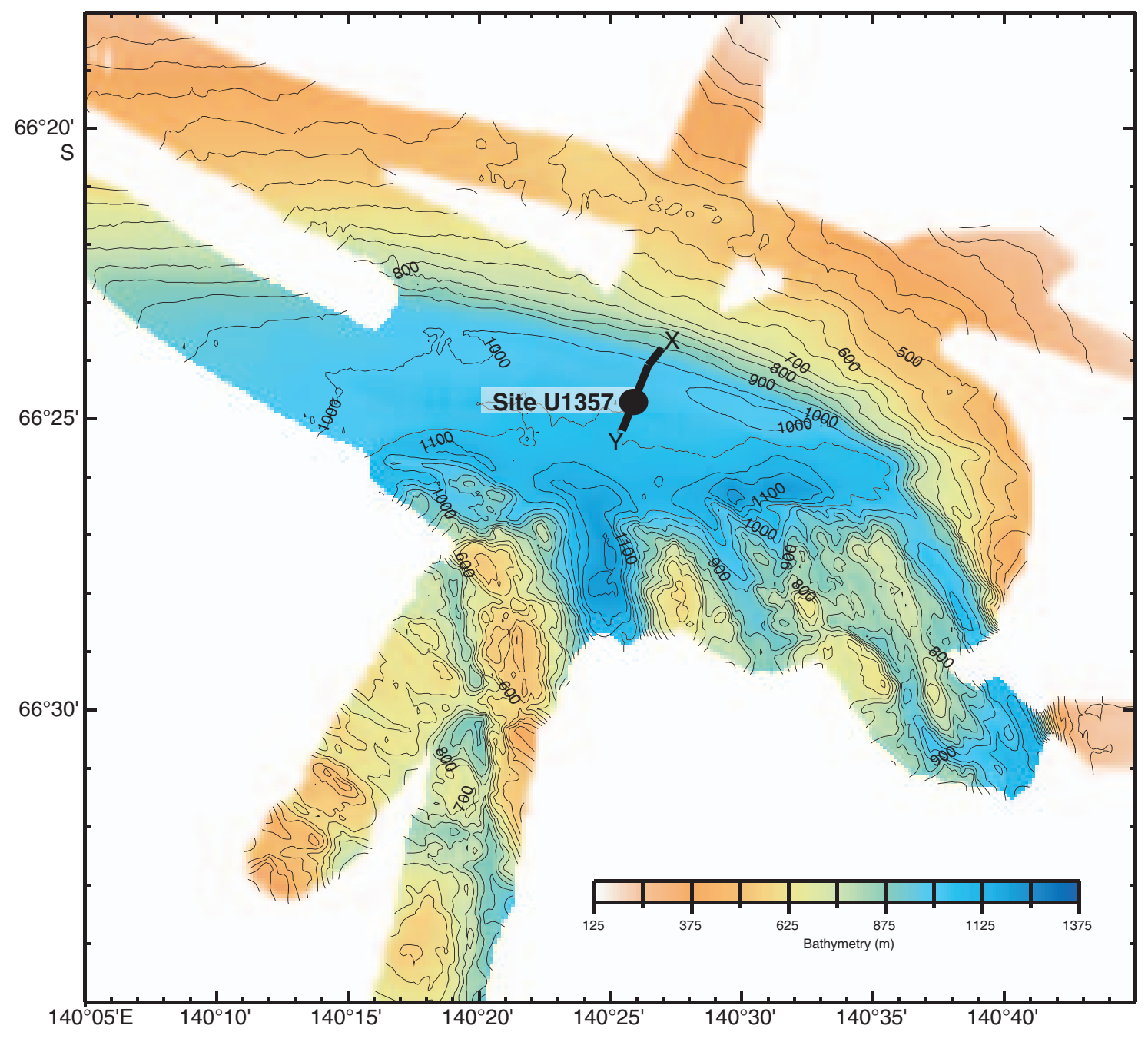


Figure F11. ODEC 2000 single-channel seismic line collected from northeast (X) to southwest (Y) across Site U1357. Red bar = approximate section cored in Holes U1357A-U1357C. Location of seismic profile is shown in Figure F10.

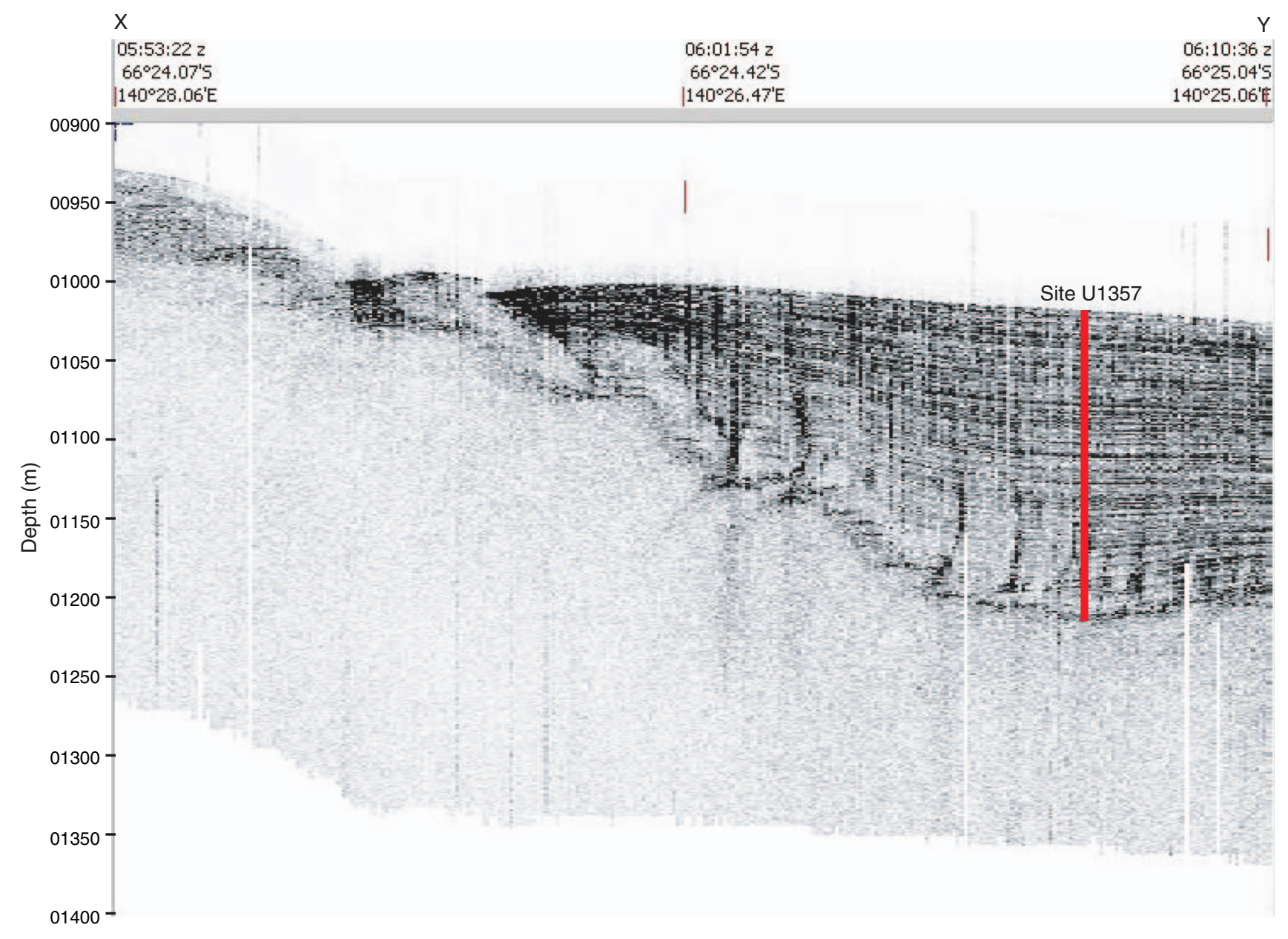


Figure F12. East Antarctic Ice Sheet evolution in the Wilkes Land margin and timing of events (modified from Escutia et al., 2005) inferred from continental shelf and rise stratigraphy (i.e., seismic regional unconformities and units).

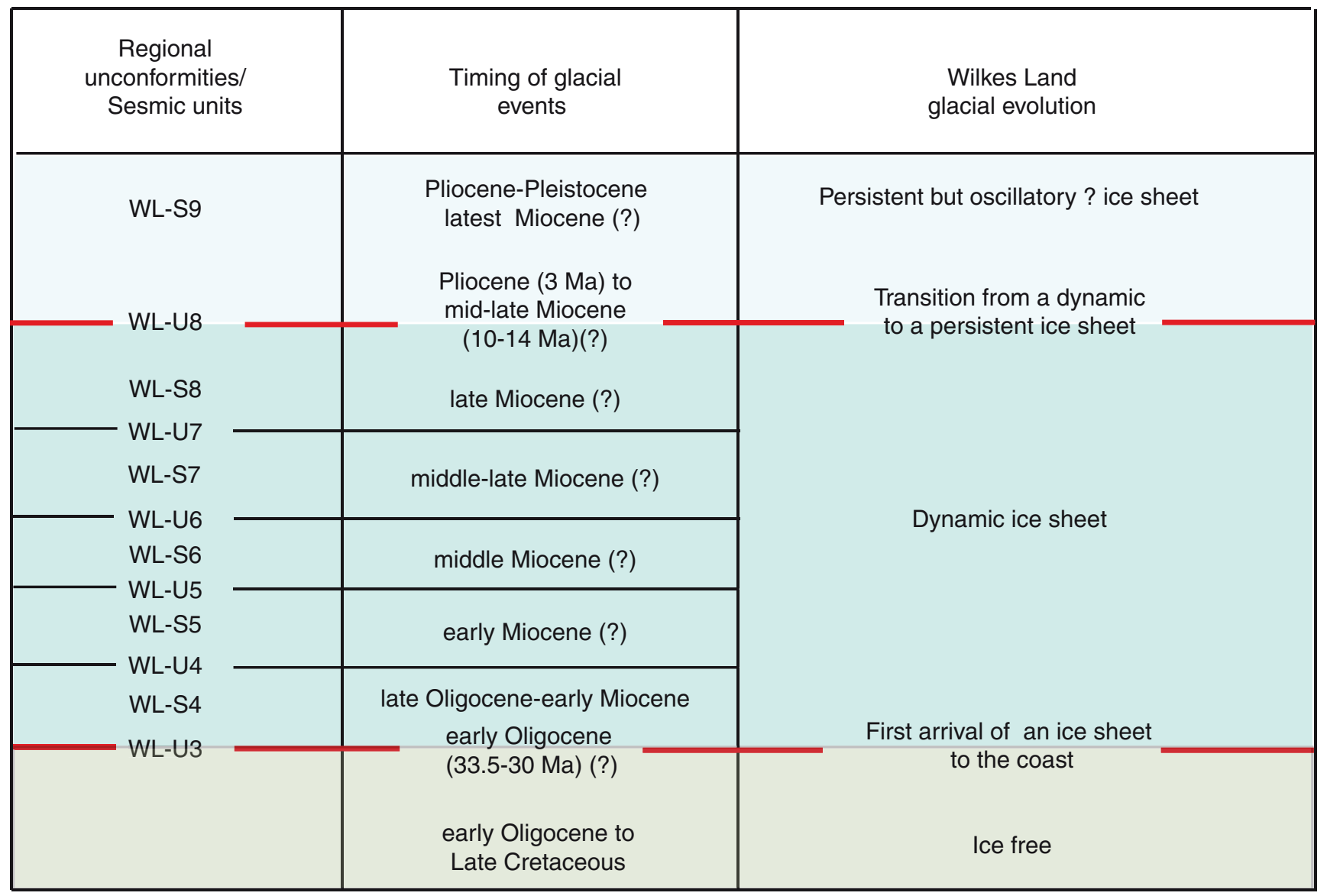


Figure F13. A. Bathymetric map of eastern Wilkes Land margin showing the location of Site U1355 and other Expedition 318 drill sites. Contour interval $=250 \mathrm{~m}$. Box $=$ approximate area of B. B. Navigation map of seismic reflection profiles across and in the vicinity of Site U1355. Bold lines $=$ multichannel seismic reflection profiles shown in Figure F14.

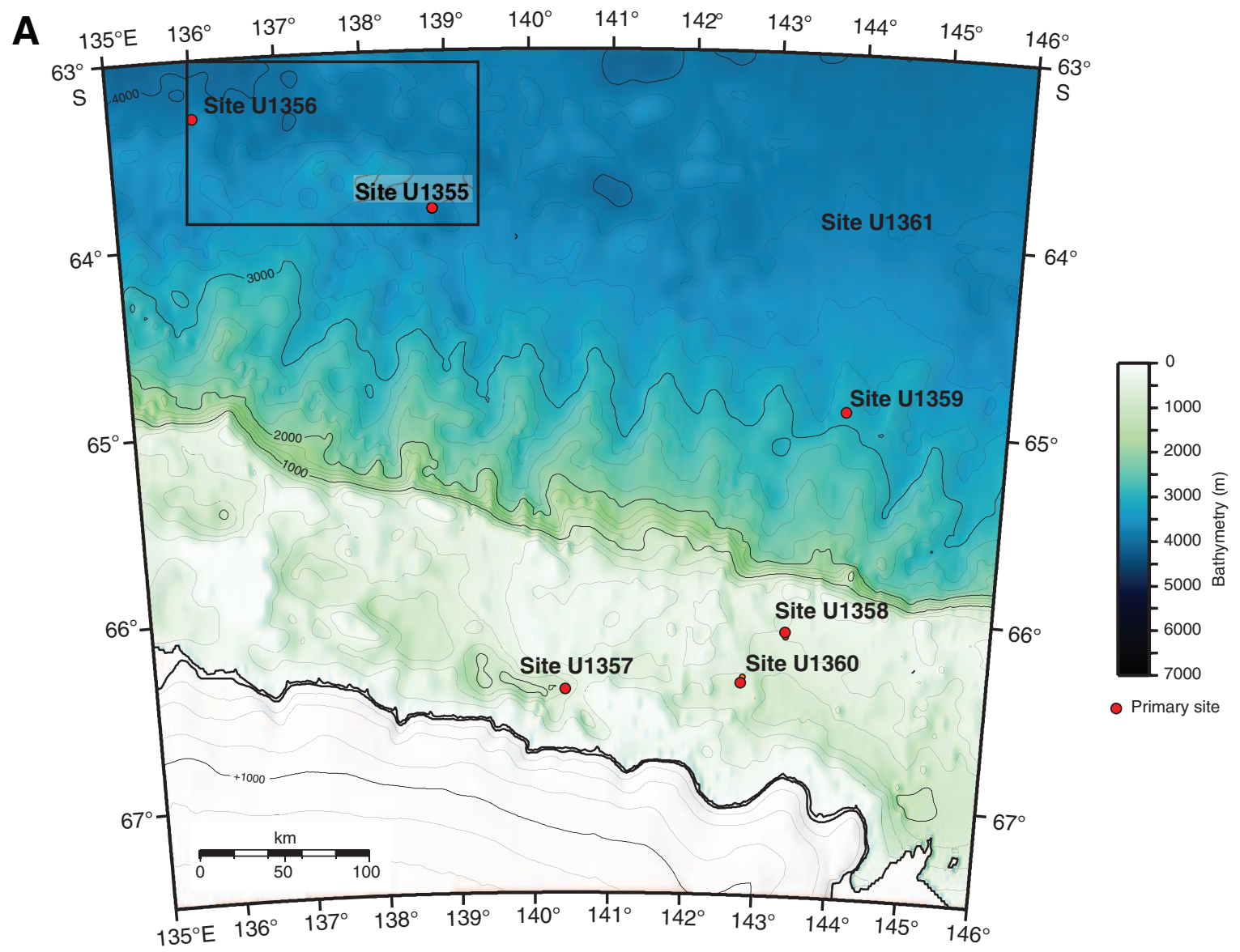

B

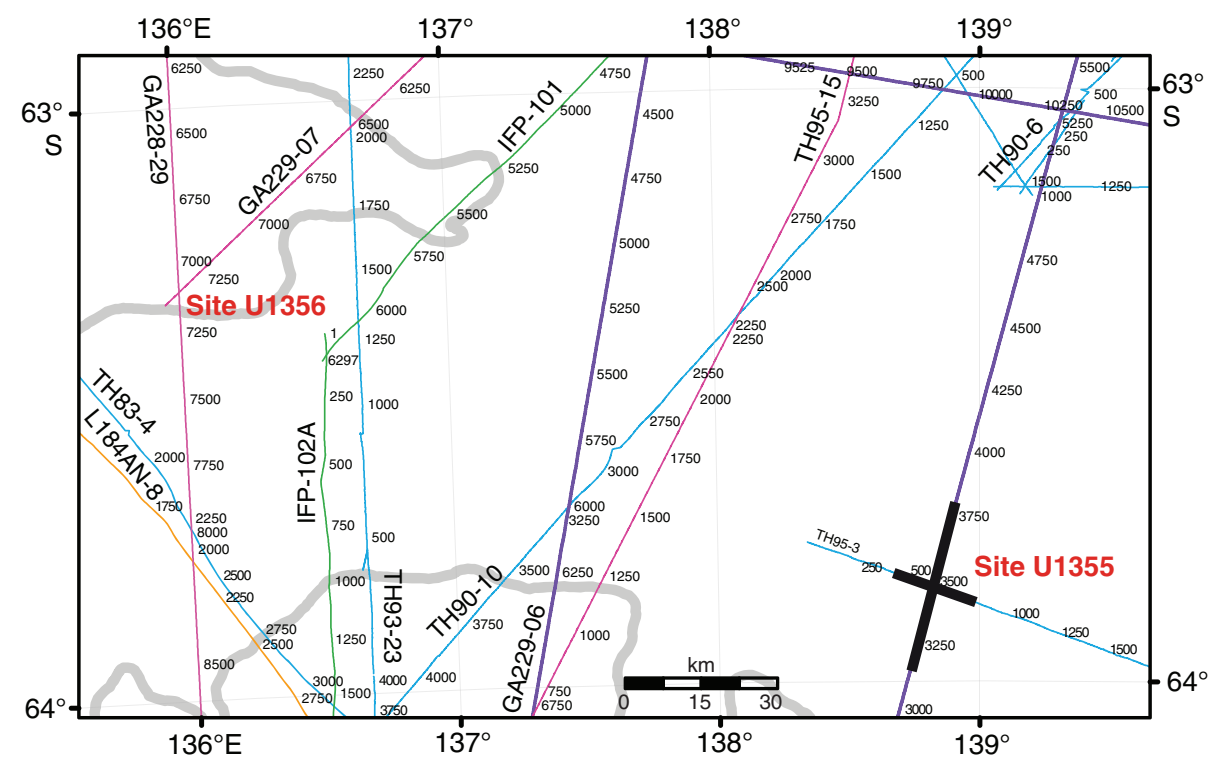


Figure F14. Seismic reflection profiles across Site U1355 showing regional unconformities WL-U3, WL-U4, and WL-U5. Filled red rectangle indicates approximate, very shallow penetration achieved at Site U1355 as compared to the target penetration depth (open rectangle). Location of seismic profiles is shown in Figure F13.
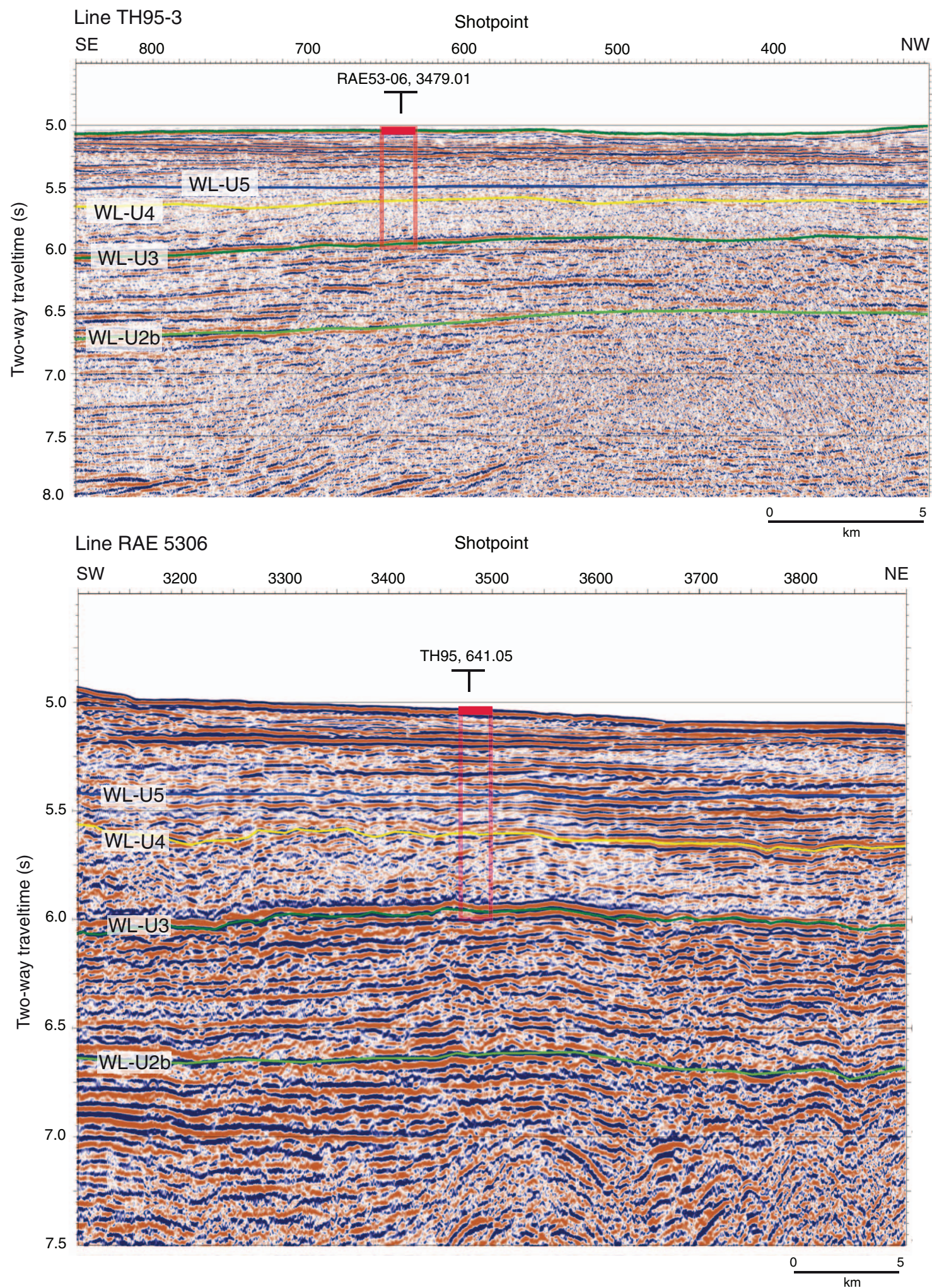
Figure F15. A. Bathymetric map of eastern Wilkes Land margin showing the location of Site U1356 and other Expedition 318 drill sites. Contour interval $=250 \mathrm{~m}$. Box $=$ approximate area of B. B. Navigation map of seismic reflection profiles across and in the vicinity of Site U1356. Bold line $=$ multichannel seismic reflection profile shown in Figure F16.

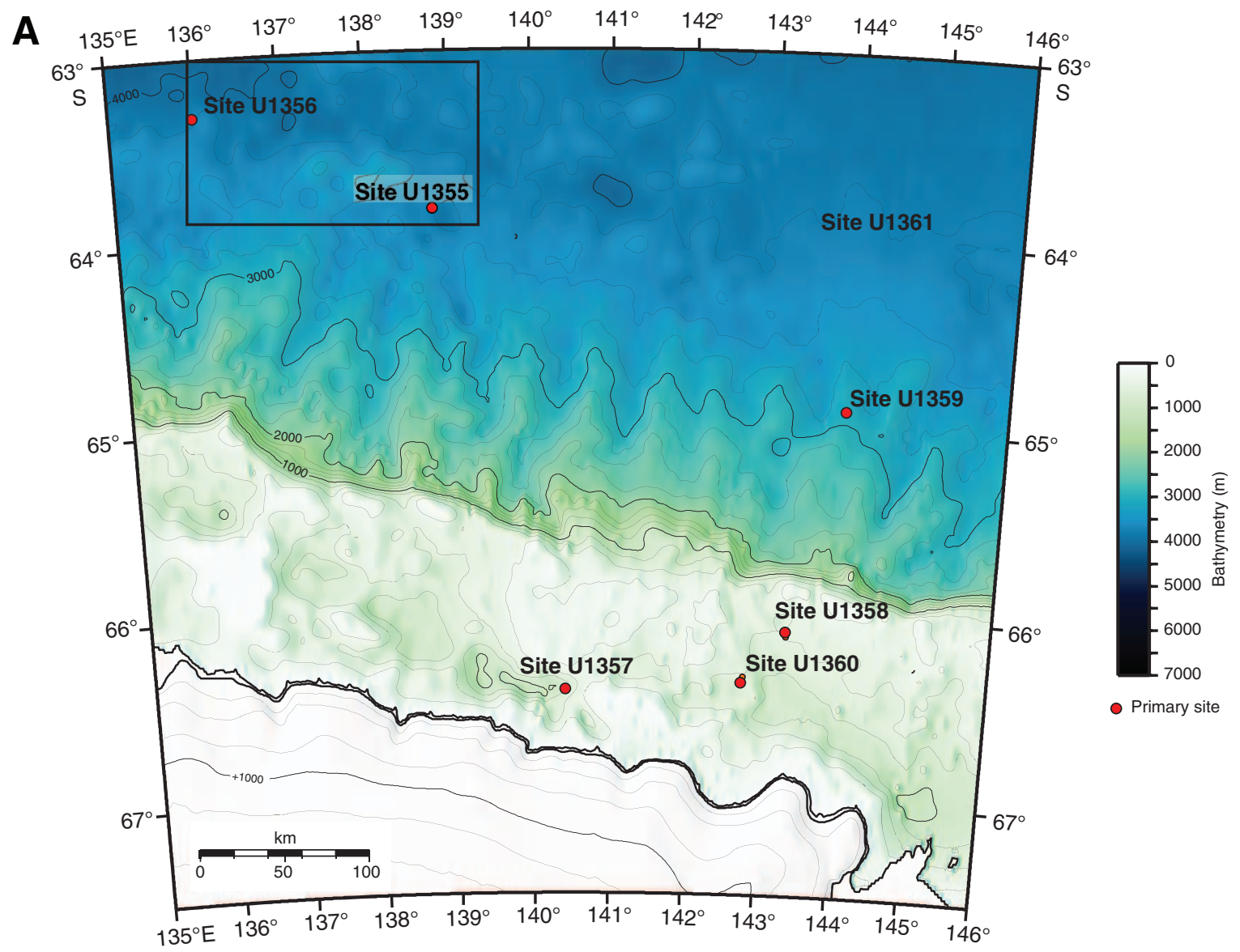

B

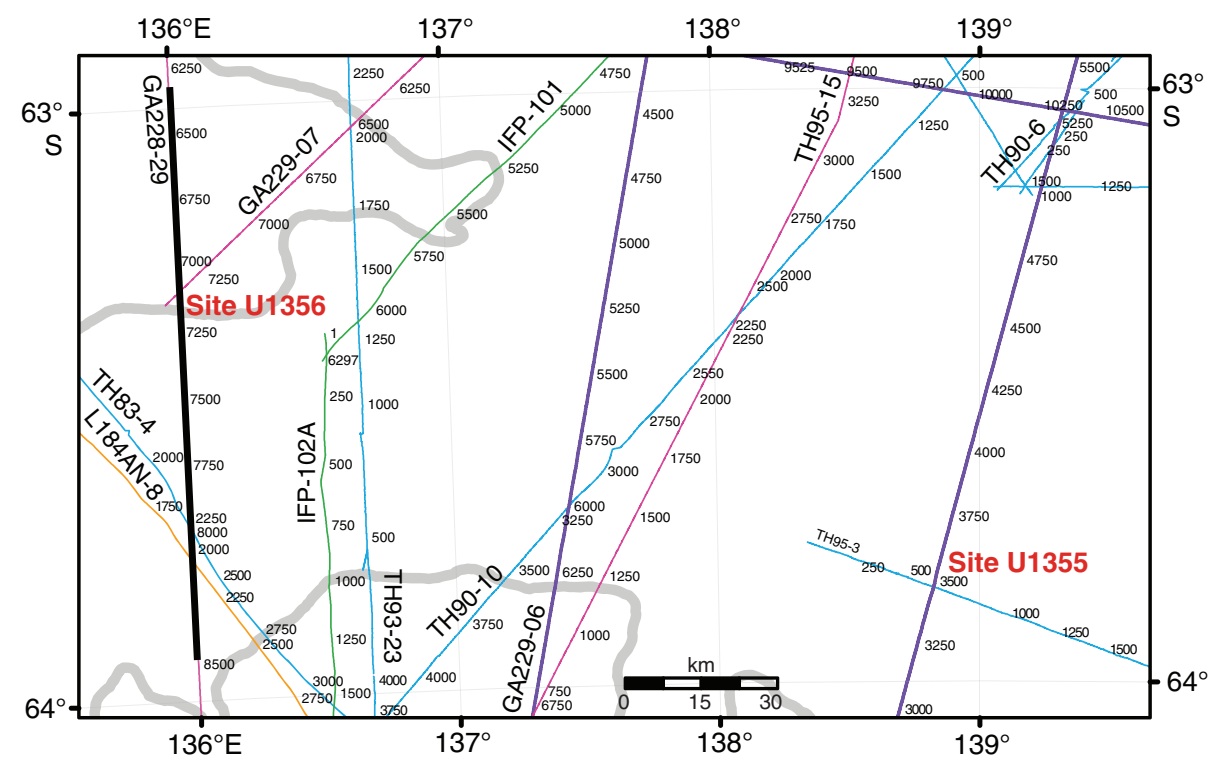


Figure F16. Multichannel seismic reflection profile across Site U1356 showing regional unconformities WL-U3, WL-U4, and WL-U5. Red rectangle $=$ approximate penetration achieved at Site U1356. Location of seismic profile is shown in Figure F15.

Shotpoint

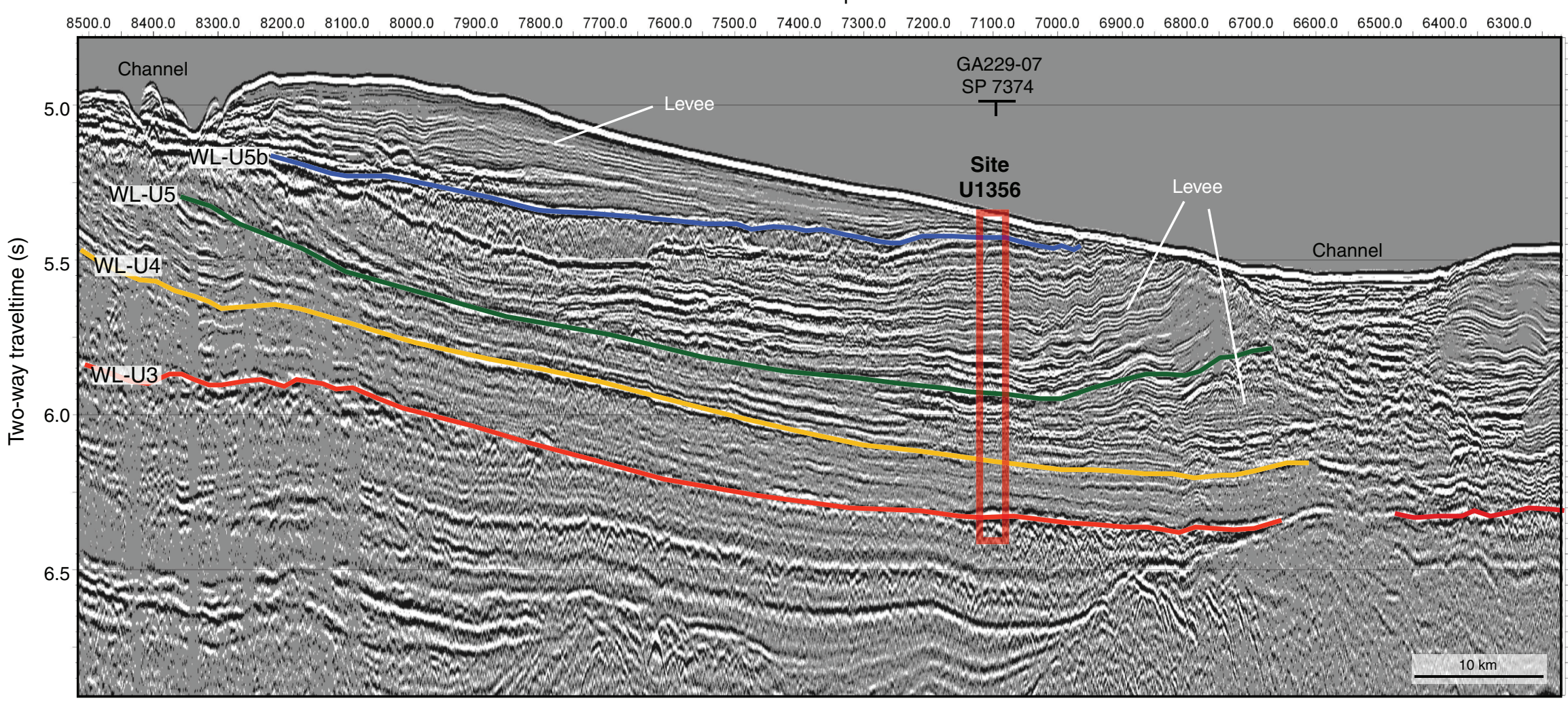


Figure F17. Bathymetric map of eastern Wilkes Land continental shelf showing the location of Sites U1357, U1358, and U1360. Bold black line = multichannel seismic reflection Profile IFP 107 shown in Figures F18 and F21.

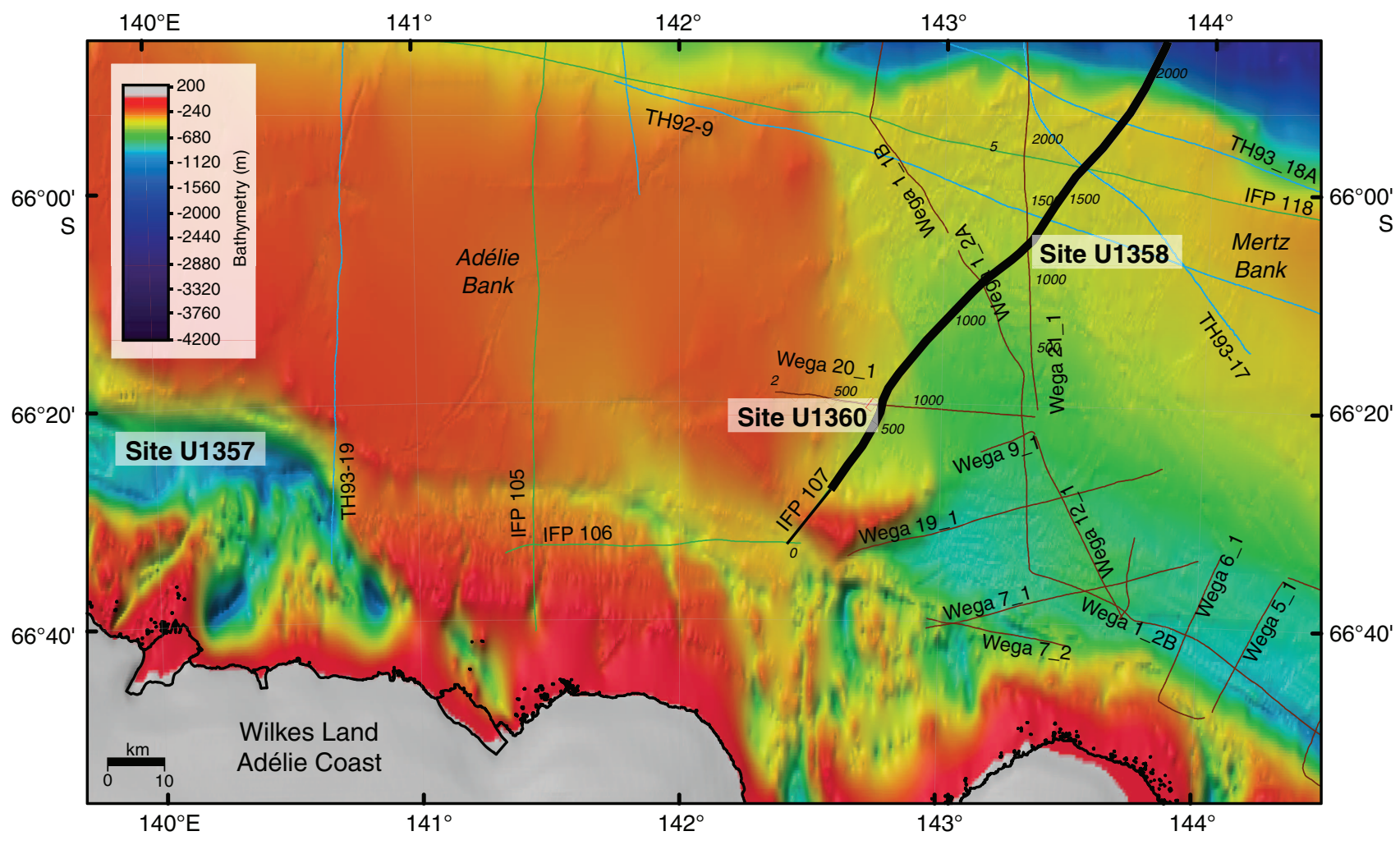


Figure F18. Multichannel seismic reflection Profile IFP 107 across Site U1358. Profile shows main regional unconformities defined in the Wilkes Land continental shelf. Drilling at Site U1358 targeted unconformity WL-U8. Red rectangle = approximate penetration achieved at Site U1358. Location of seismic profile is shown in Figure F17.

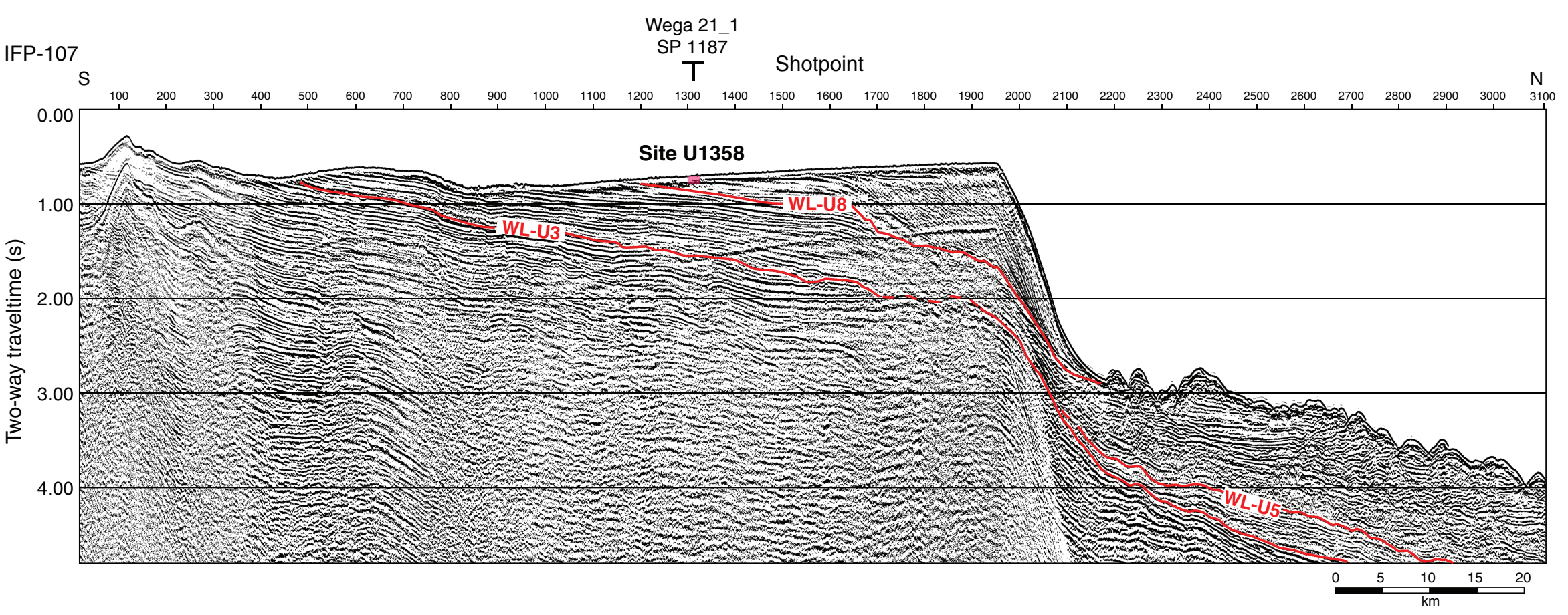


Figure F19. Bathymetric map of eastern Wilkes Land margin showing the location of Site U1358, U1359, and U1361. Contour interval $=250 \mathrm{~m}$. Bold line $=$ multichannel seismic reflection profile shown in Figure F20.

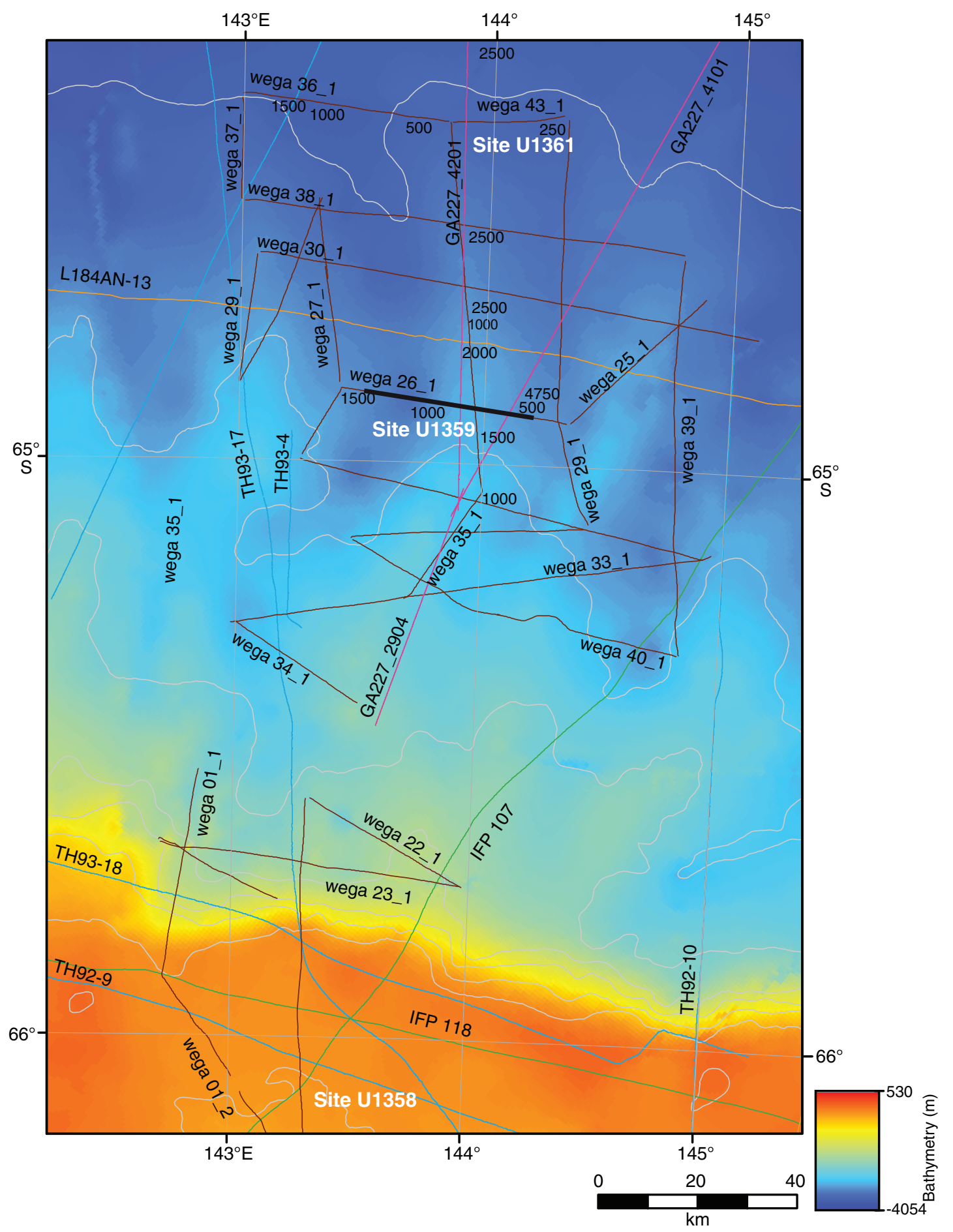


Figure F20. Multichannel seismic reflection profile across Site U1359 showing regional unconformities WL-U3, WL-U4, and WL-U5 targeted by drilling. Red rectangle = approximate penetration achieved at Site U1359. Location of seismic profiles is shown in Figure F19.

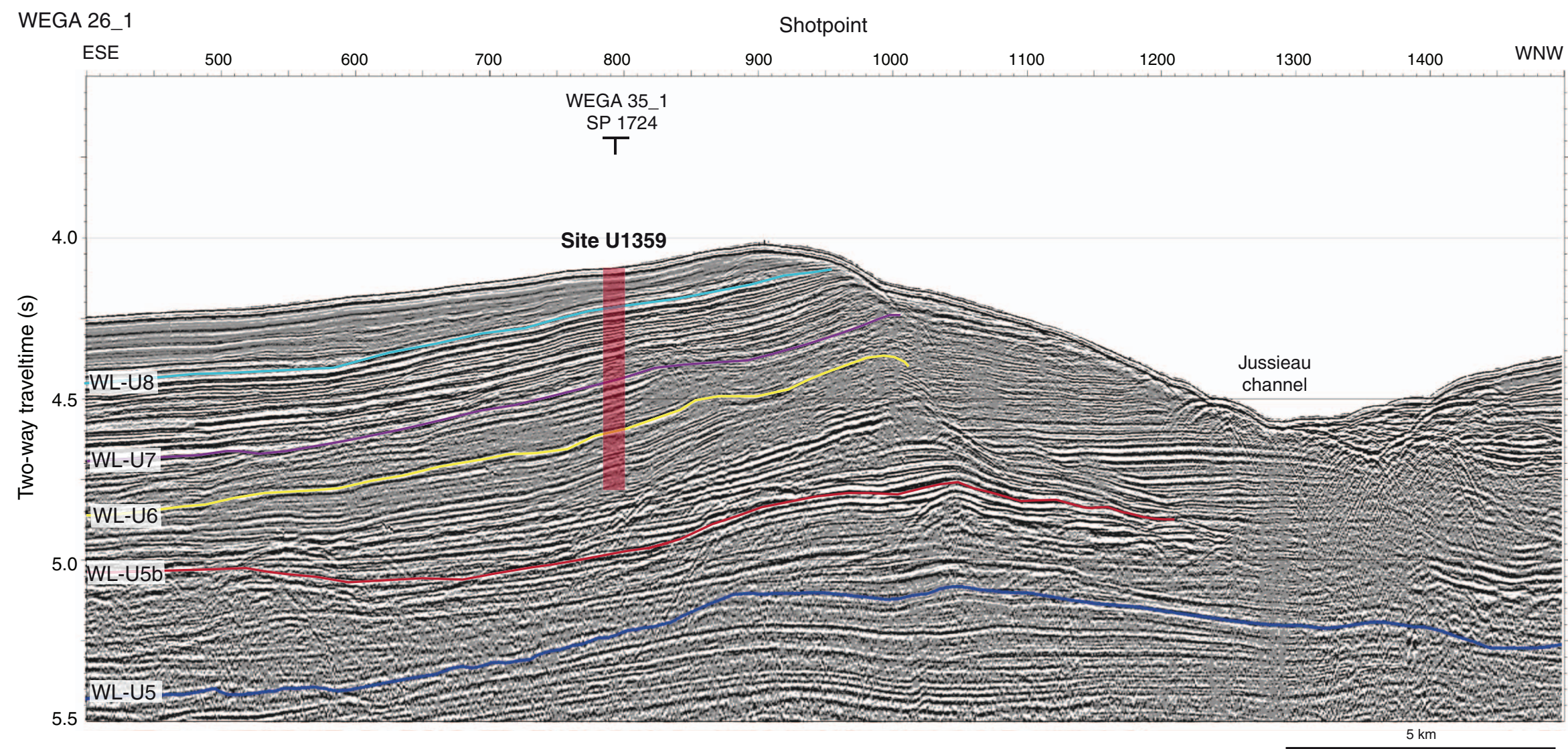


Figure F21. Multichannel seismic reflection Profile IFP 107 across Site U1360. Profile shows the main regional unconformities defined in the Wilkes Land continental shelf. Drilling at Site U1360 targeted unconformity WL-U3. Red rectangle = approximate penetration achieved at Site U1360. Location of seismic profile is shown in Figure F17.

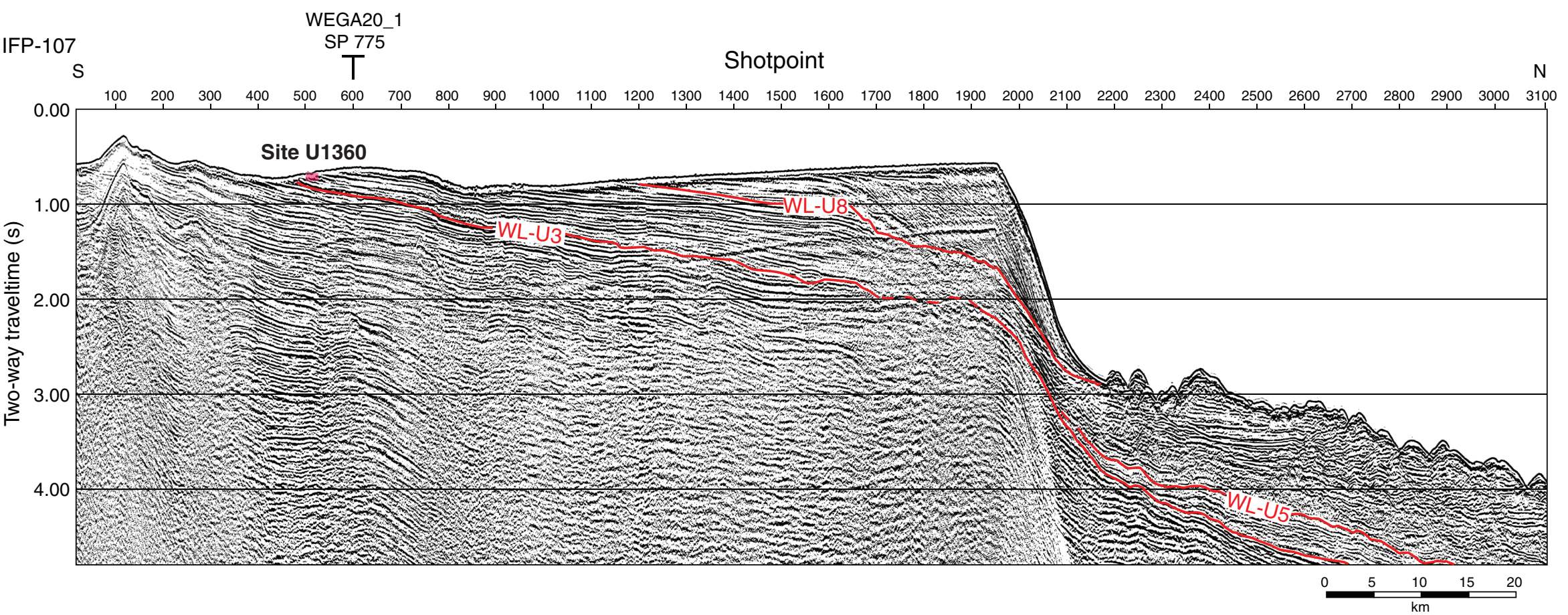


Figure F22. Bathymetric map of eastern Wilkes Land margin showing the location of Site U1361. Bold line = multichannel seismic reflection profile shown in Figure F23.

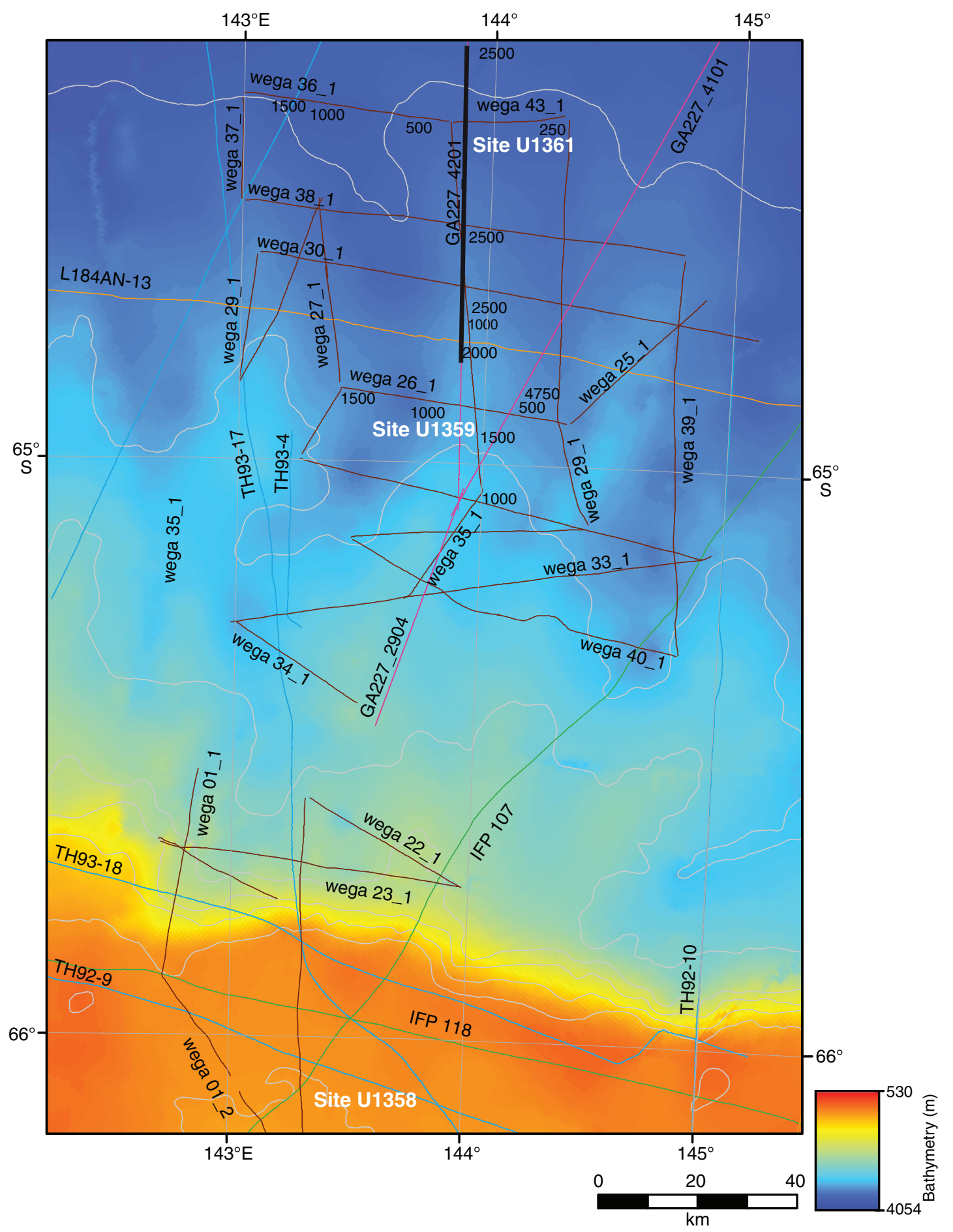


Figure F23. Multichannel seismic reflection profile across Site U1361 showing regional unconformities WLU5-WLU8 targeted by drilling. Red rectangle $=$ approximate penetration achieved at Site U1361. Location of seismic profiles is shown in F22.

GA227 4201

SE

1800

1900

2000

Shotpoint

2200

2100

2400

2500

2600

NW

WEGA 43_01

SP 829

4.5

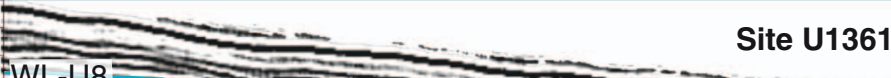

$\mathrm{WL}-\mathrm{U} 8 \cong \mathrm{NON}=$

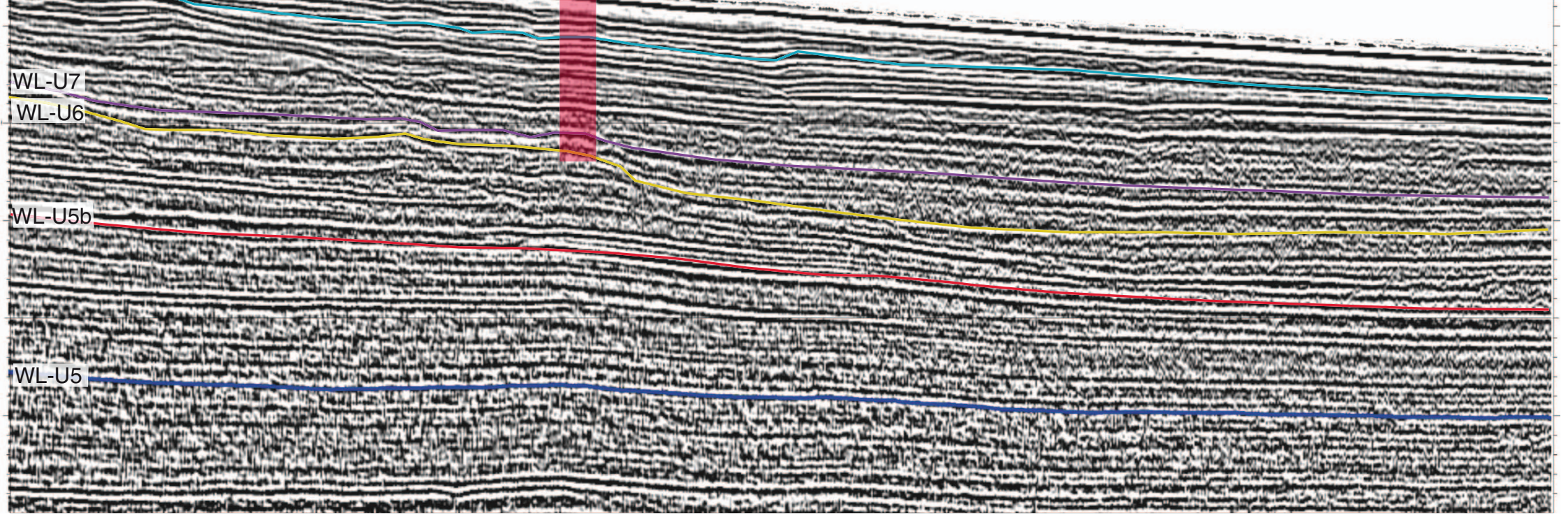


Figure F24. Stacked deep-sea benthic foraminifer oxygen isotope curve for 0-65 Ma (updated from Zachos et al., 2008) converted into Gradstein timescale (Gradstein et al., 2004), and combined with chronostratigraphy of the sites drilled during Expedition 318. ETM2 = Eocene Thermal Maximum 2, PETM = Paleocene/Eocene Thermal Maximum, ETM1 = Eocene Thermal Maximum 1.

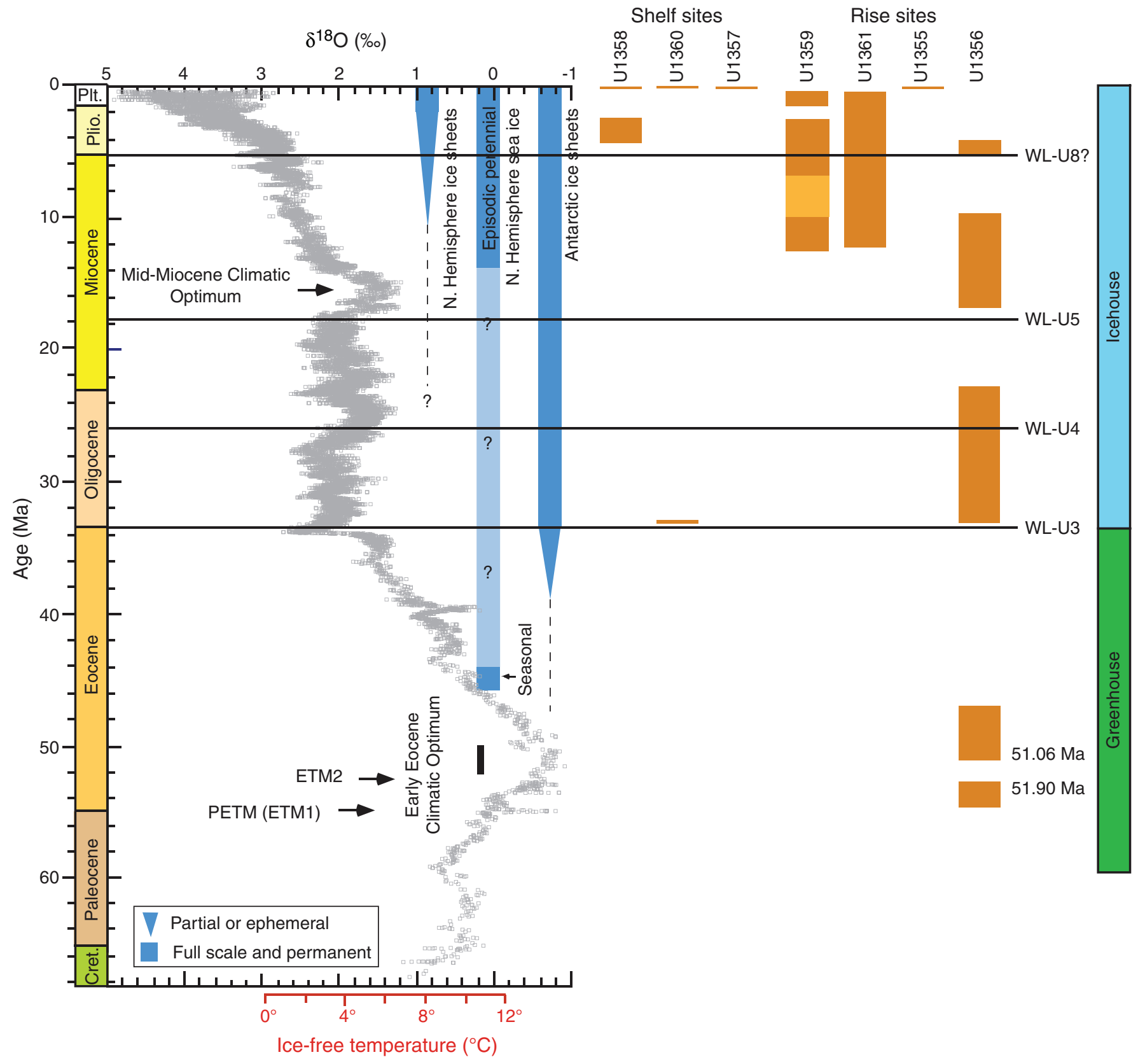


Figure F25. Chronostratigraphic framework for sites drilled during Expedition 318. Timescales are those of Gradstein et al. (2004).
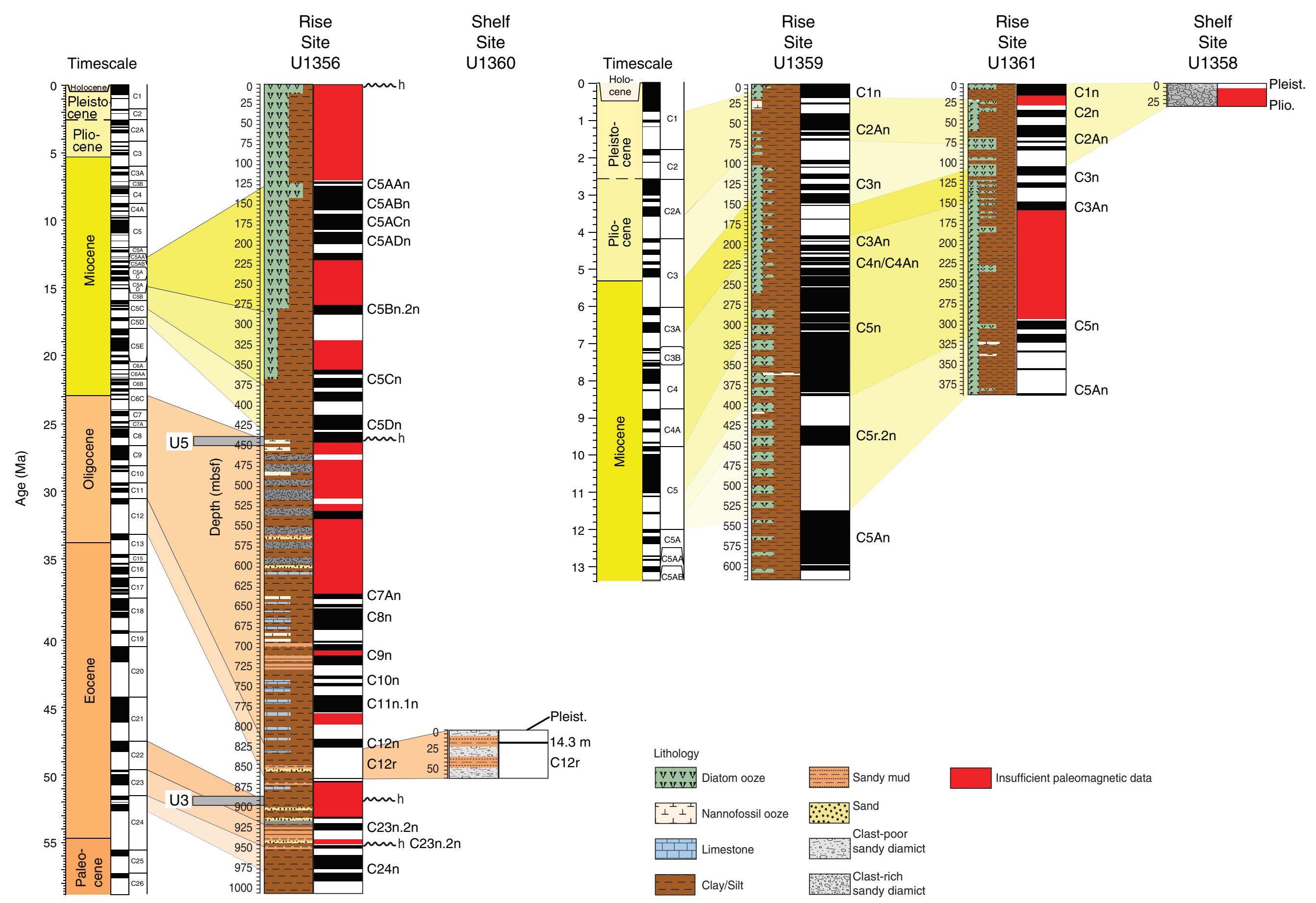
Sandy mud
Fand
Limestone $\quad$ Castroor

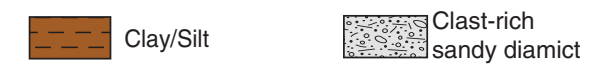


Figure F26. Conceptual illustration of tectonic, geological, sedimentological, and climatic evolution of the Wilkes Land margin since the middle early Eocene ( 54 Ma). U3, U4, and U5 refer to seismic unconformities WL-U3, WL-U4, and WL-U5. Oi-1 = Oligocene isotope Event 1, CPDW = Circumpolar Deep Water, ACSC = Antarctic Circumpolar Surface Water, UCPDW = Upper Circumpolar Deep Water, LCPDW = Lower Circumpolar Deep Water, AABW = Antarctic Bottom Water. MTD = mass transport debris flows.

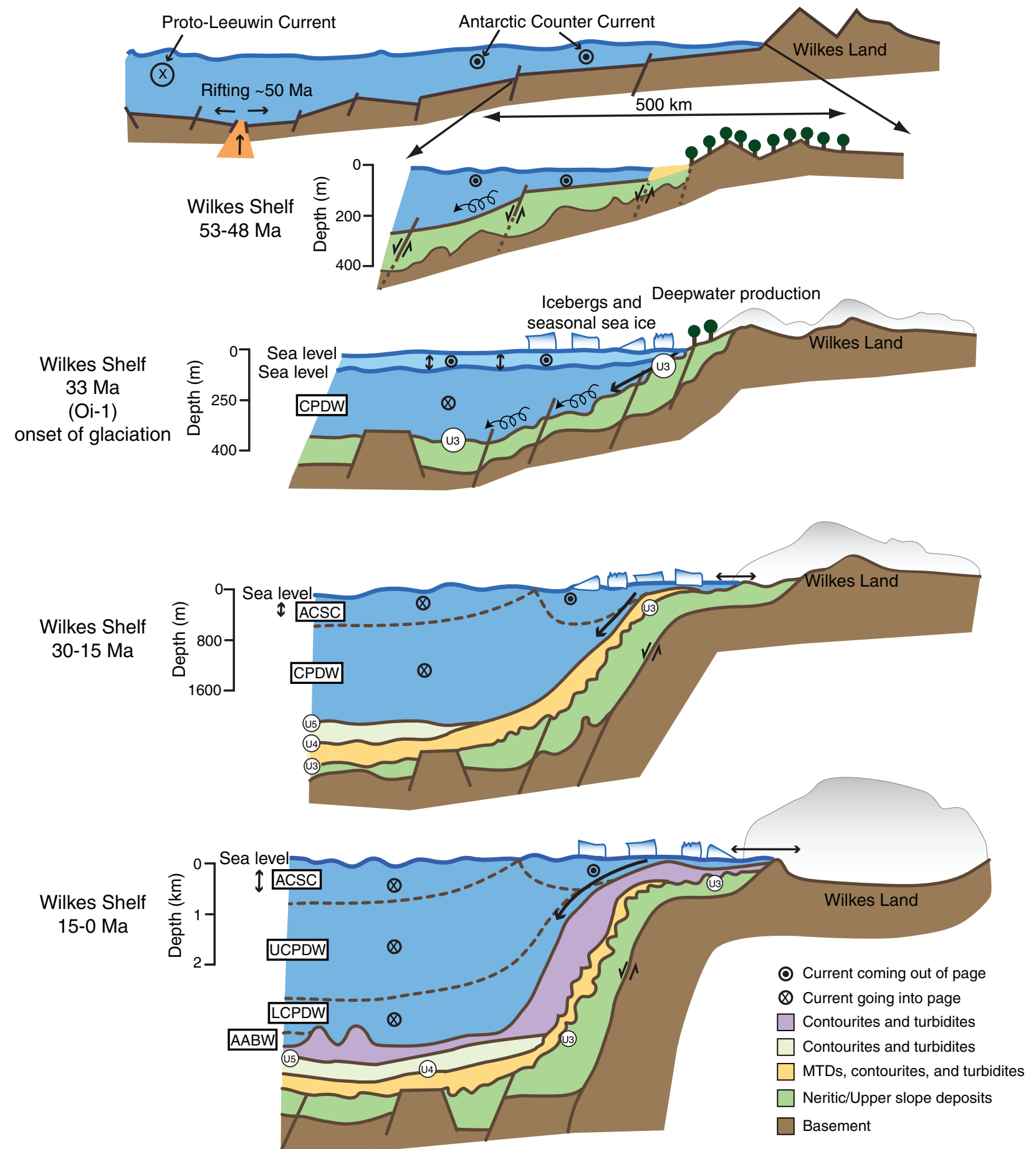


Figure F27. Summary log, Hole U1356A. Chemical index of alteration is $\left[\mathrm{Al}_{2} \mathrm{O}_{3} /\left(\mathrm{Al}_{2} \mathrm{O}_{3}+\mathrm{CaO} *+\mathrm{K}_{2} \mathrm{O}+\mathrm{Na}_{2} \mathrm{O}\right)\right]$ $\times 100$ (Nesbitt and Young, 1982). $\mathrm{CaO}^{*}$ represents the $\mathrm{CaO}$ fixed in silicate minerals; values between 50 and 70 can be observed in the upper interval. Values are intermediate between fresh feldspar (33-50) and chemically weathered detritus (70-75) and are typical for environments affected by physical weathering (e.g., Passchier and Krissek, 2008). Higher values in the lower interval (>80) strongly indicate intense chemical weathering and manifest different environmental conditions in the source area of the sediments.

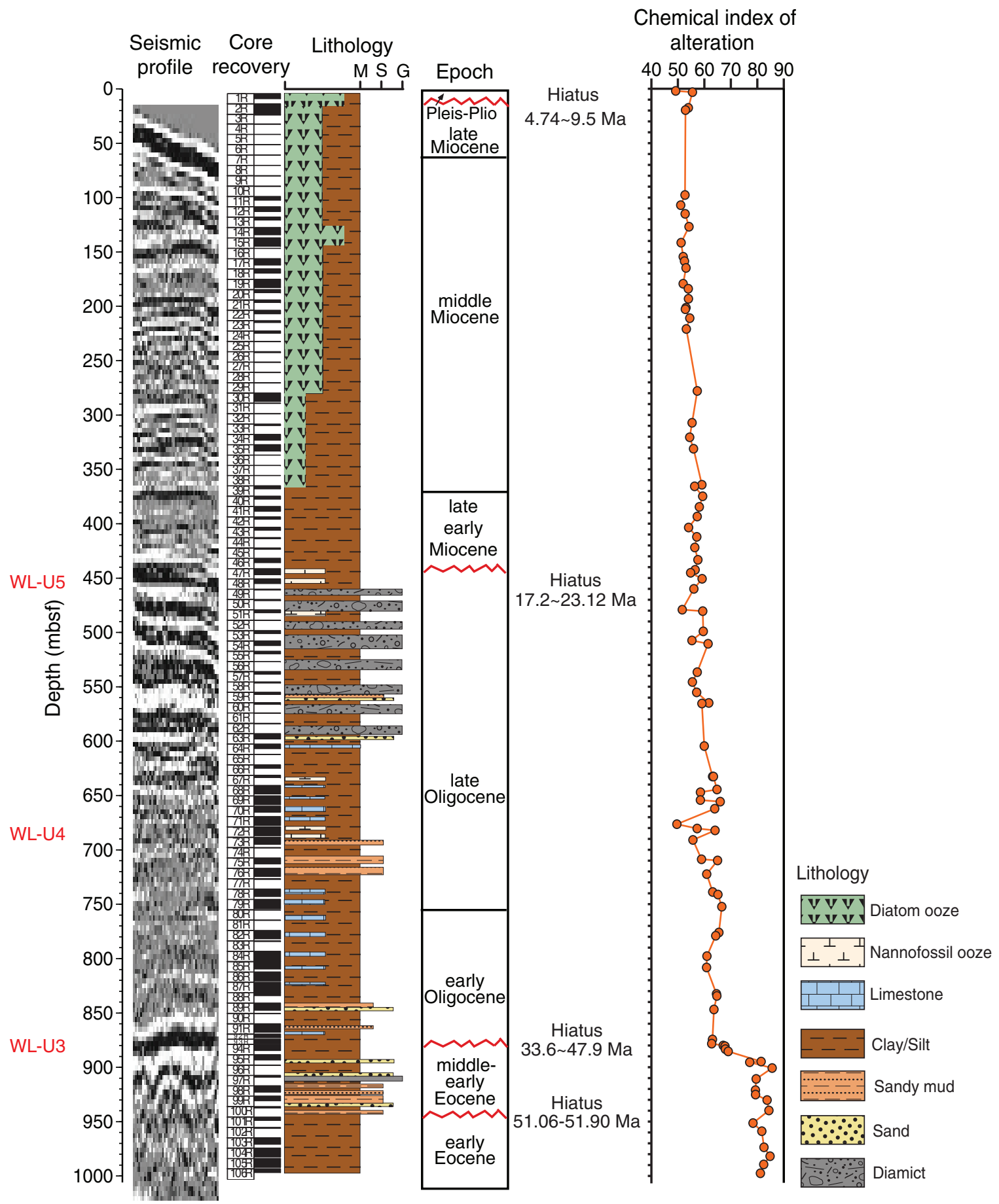


Figure F28. A-C. Conceptual illustration of tectonic and surface water evolution of the larger AustralianAntarctic sector since the middle Eocene. Black box = approximate location of Expedition 318 Wilkes Land drill sites. Modified from Kennett et al., 2001.
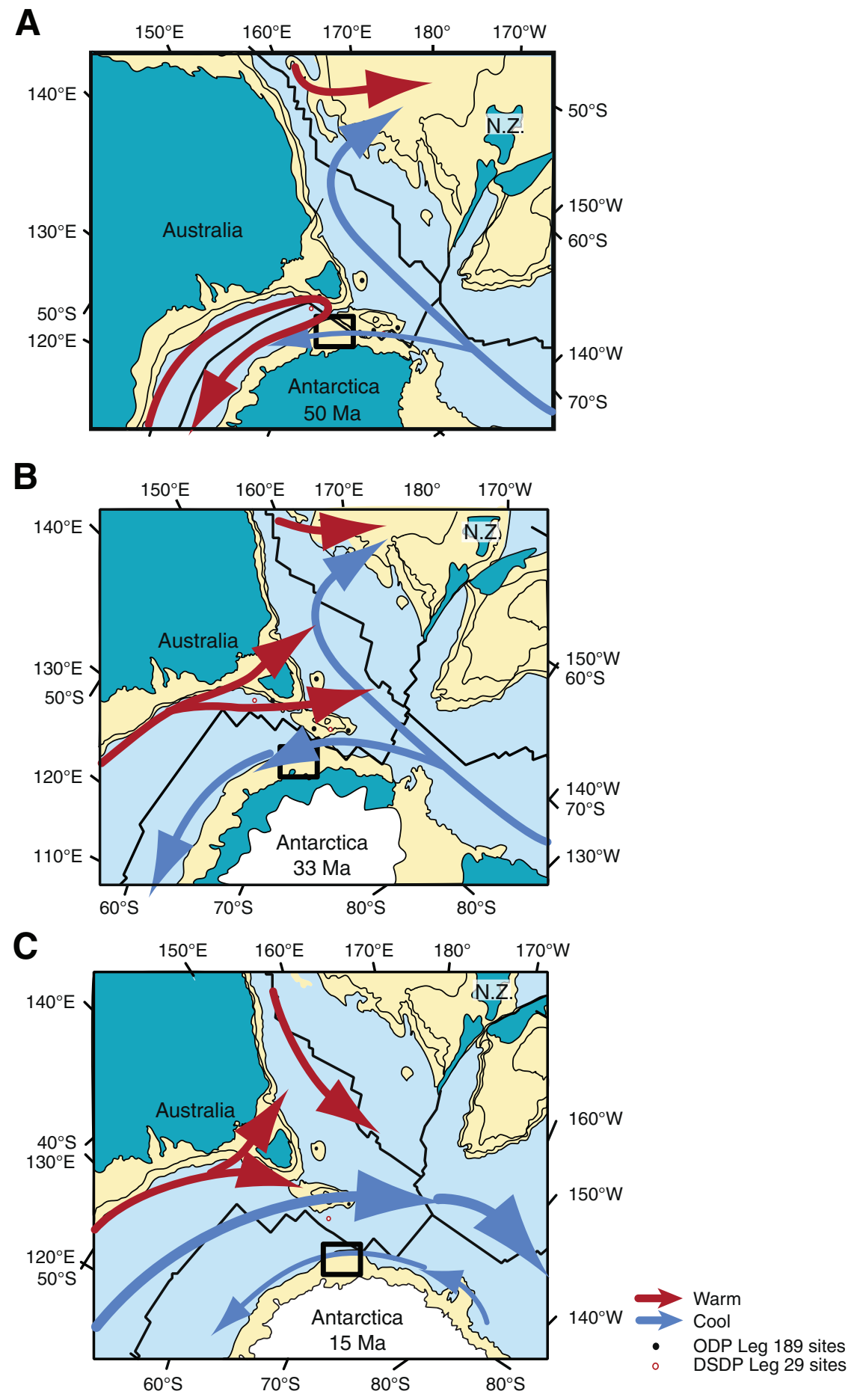
Figure F29. Example of a core section from Holocene diatomaceous ooze, Site U1357. Note the distinct seasonal laminations.

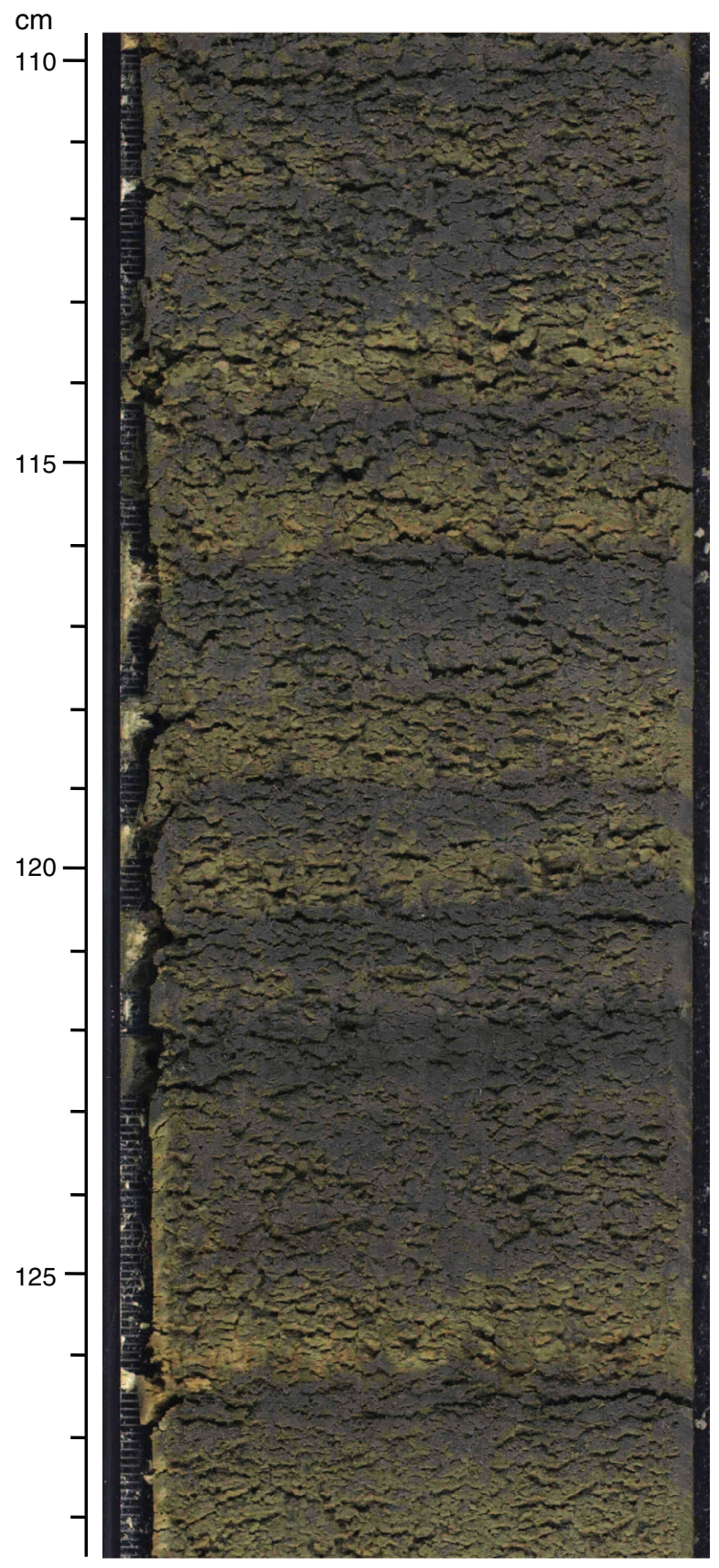


Table T1. Expedition 318 coring summary.

\begin{tabular}{|c|c|c|c|c|c|c|c|c|c|c|c|c|c|}
\hline Site & Hole & Latitude & Longitude & $\begin{array}{l}\text { Seafloor } \\
\text { depth } \\
\text { (mbrf) }\end{array}$ & $\begin{array}{l}\text { Cores } \\
(N)\end{array}$ & $\begin{array}{l}\text { Cored } \\
(\mathrm{m})\end{array}$ & $\begin{array}{l}\text { Recovered } \\
(\mathrm{m})\end{array}$ & $\begin{array}{c}\text { Recovery } \\
\text { (\%) }\end{array}$ & $\begin{array}{l}\text { Drilled } \\
(\mathrm{m})\end{array}$ & $\begin{array}{l}\text { Total } \\
\text { penetration } \\
(\mathrm{m})\end{array}$ & $\begin{array}{l}\text { Total } \\
\text { depth } \\
\text { (mbrf) }\end{array}$ & $\begin{array}{l}\text { Time on } \\
\text { hole } \\
\text { (h) }\end{array}$ & $\begin{array}{l}\text { Time on } \\
\text { site } \\
\text { (days) }\end{array}$ \\
\hline \multirow[t]{2}{*}{ U1355 } & A & $63^{\circ} 50.4704^{\prime} \mathrm{S}$ & $138^{\circ} 49.4270^{\prime} \mathrm{E}$ & 3734.0 & 4 & 31.7 & 14.95 & 47 & 0.0 & 31.7 & 3765.7 & 67.25 & \\
\hline & & & Site U13 & 55 totals: & 4 & 31.7 & 14.95 & 47 & 0.0 & 31.7 & & & 2.8 \\
\hline \multirow[t]{2}{*}{ U1356 } & A & $63^{\circ} 18.6138^{\prime} \mathrm{S}$ & $135^{\circ} 59.9376^{\prime} \mathrm{E}$ & 4003.0 & 106 & 1006.4 & 350.14 & 35 & 0.0 & 1006.4 & 5009.4 & 255.50 & \\
\hline & & & Site U13 & 56 totals: & 106 & 1006.4 & 350.14 & 35 & 0.0 & 1006.4 & & & 10.6 \\
\hline \multirow[t]{4}{*}{ U1357 } & A & $66^{\circ} 24.7991^{\prime} \mathrm{S}$ & $140^{\circ} 25.5008^{\prime} \mathrm{E}$ & 1025.9 & 21 & 186.6 & 183.87 & 99 & 0.0 & 186.6 & 1212.5 & 27.33 & \\
\hline & B & $66^{\circ} 24.7990^{\prime} \mathrm{S}$ & $140^{\circ} 25.5705^{\prime} \mathrm{E}$ & 1028.0 & 19 & 170.7 & 172.44 & 101 & 0.0 & 170.7 & 1198.7 & 16.33 & \\
\hline & C & $66^{\circ} 24.8013^{\prime} \mathrm{S}$ & $140^{\circ} 25.4651^{\prime} \mathrm{E}$ & 1027.7 & 11 & 103.8 & 110.71 & 107 & 0.0 & 103.8 & 1131.5 & 29.33 & \\
\hline & & & Site U13 & 57 totals: & 51 & 461.1 & 467.02 & 101 & 0.0 & 461.1 & & & 3.0 \\
\hline \multirow{3}{*}{ U1358 } & A & $66^{\circ} 05.4247^{\prime} \mathrm{S}$ & $143^{\circ} 18.7674^{\prime} \mathrm{E}$ & 512.0 & 1 & 2.0 & 1.10 & 55 & 0.0 & 2.0 & 514.0 & 6.75 & \\
\hline & B & $66^{\circ} 05.4244^{\prime} \mathrm{S}$ & $143^{\circ} 18.7666^{\prime} \mathrm{E}$ & 512.0 & 4 & 35.6 & 8.00 & 22 & 0.0 & 35.6 & 547.6 & 15.25 & \\
\hline & & & Site U13 & 58 totals: & 5 & 37.6 & 9.10 & 24 & 0.0 & 37.6 & & & 0.9 \\
\hline \multirow[t]{5}{*}{ U1359 } & A & $64^{\circ} 54.2377^{\prime S}$ & $143^{\circ} 57.6825^{\prime} \mathrm{E}$ & 3020.9 & 22 & 193.5 & 154.08 & 80 & 0.0 & 193.5 & 3214.4 & 34.00 & \\
\hline & B & $64^{\circ} 54.2431^{\prime} \mathrm{S}$ & $143^{\circ} 57.6553^{\prime} \mathrm{E}$ & 3018.8 & 28 & 252.0 & 198.92 & 79 & 0.0 & 252.0 & 3270.8 & 29.67 & \\
\hline & C & $64^{\circ} 54.2477^{\prime} \mathrm{S}$ & $143^{\circ} 57.6248^{\prime} \mathrm{E}$ & 3022.3 & 18 & 168.7 & 150.73 & 89 & 0.0 & 168.7 & 3191.0 & 25.58 & \\
\hline & D & $64^{\circ} 54.2596^{\prime} \mathrm{S}$ & $143^{\circ} 57.5624^{\prime} \mathrm{E}$ & 3023.0 & 47 & 450.0 & 269.72 & 60 & 152.2 & 602.2 & 3625.2 & 120.50 & \\
\hline & & & Site U13 & 59 totals: & 115 & 1064.2 & 773.45 & 73 & 152.2 & 1216.4 & & & 8.7 \\
\hline \multirow[t]{2}{*}{ U1360 } & A & $66^{\circ} 22.0395^{\prime} \mathrm{S}$ & $142^{\circ} 44.7050^{\prime} \mathrm{E}$ & 506.0 & 7 & 70.8 & 7.04 & 10 & 0.0 & 70.8 & 576.8 & 31.00 & \\
\hline & & & Site U13 & 60 totals: & 7 & 70.8 & 7.04 & 10 & 0.0 & 70.8 & & & 1.3 \\
\hline \multirow[t]{4}{*}{ U1361 } & A & $64^{\circ} 24.5728^{\prime} \mathrm{S}$ & $143^{\circ} 53.1992^{\prime} \mathrm{E}$ & 3465.5 & 41 & 388.0 & 338.86 & 87 & 0.0 & 388.0 & 3853.5 & 106.33 & \\
\hline & B & $64^{\circ} 24.5454^{\prime} \mathrm{S}$ & $143^{\circ} 53.1966^{\prime} \mathrm{E}$ & 3466.9 & 2 & 12.1 & 12.04 & 100 & 0.0 & 12.1 & 3479.0 & 18.42 & \\
\hline & & & Site U13 & 61 totals: & 43 & 400.1 & 350.90 & 88 & 0.0 & 400.1 & & & 5.2 \\
\hline & & & Expedition 3 & 18 totals: & 331 & 3071.9 & 1972.60 & 64 & 152.2 & 3224.1 & & 783.25 & 32.6 \\
\hline
\end{tabular}

